\title{
Evaluation of Potential \\ Severe Accidents During \\ Low Power and Shutdown \\ Operations at Surry, Unit 1
}

\section{Summary of Results}

Manuscript Completed: September 1995

Date Published: October 1995

Edited by T.L. Chu and W. T. Pratt

Contributing Authors

T.L. Chu, Z. Musicki, P. Kohut, J. Jo, C.C. Lin, L. Neymotin, V. Mubayi, R.J. Budnitz, 1

P.R. Davis, ${ }^{2}$ M.K. Ravindra, ${ }^{3}$ W. H. Tong, ${ }^{3}$ D. Bley, ${ }^{4}$ J. Yang, B. Holmes, ${ }^{5}$ G. Bozoki, C. J. Hsu,

D.J. Diamond, D. Johnson, ${ }^{4}$ J. Lin, ${ }^{4}$ R. F. Su, ${ }^{6}$ V. Dang, ${ }^{6}$ D. Iberg, ${ }^{7}$ S.M. Wong, N. Siu, ${ }^{6}$

Y.M. Hou ${ }^{4}$

Brookhaven National Laboratory

Upton, NY 11973-5000

R. Robinson, NRC Project Manager

Prepared for

Division of Systems Technology

Office of Nuclear Regulatory Research

U.S. Nuclear Regulatory Commission

Washington, DC 20555-0001

NRC FIN L1922

1Future Resources Associated, Inc., Berkeley, CA 94704

2PRD Consulting, Sheridan, WY 82801

${ }^{3} \mathrm{EQE}$ International, Inc., Irvine, CA 92715

4PLG, Inc., Newport Beach, CA 92660

5 AEA Technology, Risley, Warrington, England

${ }^{6} \mathrm{MIT}$, Cambridge, MA 02139

${ }^{7}$ Soreq Nuclear Research Center, Yavne 70600, Israel 


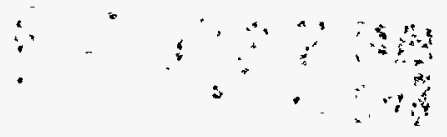




\section{DISCLAMMER}

Portions of this document may be illegible in electronic image products. Images are produced from the best available original document. 
$\mid$ 


\begin{abstract}
During 1989, the Nuclear Regulatory Commission (NRC) initiated an extensive program to carefully examine the potential risks during low power and shutdown operations. Two plants, Surry (pressurized water reactor) and Grand Gulf (boiling water reactor), were selected as the plants to be studied by Brookhaven National Laboratory (BNL) and Sandia National Laboratories (SNL), respectively. The objectives of the program are to assess the risks of severe accidents initiated during plant operational states (POSs) other than full power operation and to compare the estimated core damage frequencies (CDFs), important accident sequences and other qualitative and quantitative results with those accidents initiated during full power operation as assessed in NUREG-1150. The scope of the program includes that of a Level 3 PRA for internal events and a Level 1 PRA for seismically induced and internal fire and flood induced core damage sequences.
\end{abstract}

The objective of this report, NUREG/CR-6144, is to document the approach utilized in the PRA for the Surry plant, and discuss the results obtained. A phased approach was used in the Level 1 program. In Phase 1, which was completed in Fall 1991, a coarse screening analysis examining accidents initiated by internal events (including internal fire and flood) was performed for all plant operational states. The objective of the Phase 1 study was to identify potential vulnerable plant configurations, to characterize (on a high, medium, or low CDF basis) the potential core damage accident scenarios and risk, and to provide a foundation for a detailed Phase 2 analysis.

In Phase 2, mid-loop operation was selected as the plant configuration to be analyzed based on the results of the Phase 1 study. The objective of the Phase 2 study is to perform a detailed analysis of the potential accident scenarios that may occur during mid-loop operation, and compare the results with those of NUREG-1150. The scope of the Phase 2 study includes a Level 3 PRA. This volume summarizes the approach and results of the study. The internal events analysis is documented in Volume 2, which also contains an appendix that documents those parts of the Phase 1 study that deal with POSs other than mid-loop operation. Internal fire and internal flood analyses are documented in Volumes 3 and 4. A separate study on seismic analysis, documented in Volume 5, was performed for the NRC by Future Resources Associates, Inc. Volume 6 documents the accident progression, source terms, and risk analysis.

The core damage frequencies (per year) of the Surry plant due to different initiating events that may take place during mid-loop operations are estimated as follows:

\begin{tabular}{lccc}
\hline Initiating Events & Mean & 5th Percentile & 95th Percentile \\
\hline Internal Events & 5E-06 & $5 \mathrm{E}-07$ & 2E-05 \\
Internal Fires & 2E-05 & $1 \mathrm{E}-06$ & $8 \mathrm{E}-05$ \\
Internal Floods & $5 \mathrm{E}-06$ & $2 \mathrm{E}-07$ & $2 \mathrm{E}-05$ \\
Seismic Events EPRA Hazard Curves & $9 \mathrm{E}-08$ & $3 \mathrm{E}-10$ & $4 \mathrm{E}-07$ \\
Seismic Events LLNL Hazard Curves & $4 \mathrm{E}-07$ & $1 \mathrm{E}-09$ & $1 \mathrm{E}-06$ \\
\hline
\end{tabular}

This can be compared with the mean core damage frequency from internal events of $4 \mathrm{E}-05$ per year estimated in the NUREG-1150 study for full power operations.

The offsite risk estimates for latent health effects of accidents during mid-loop operation were similar to the risk estimates for full power operation. The early health consequences are much lower than the full power results primarily due to the long time after reactor trip when the accidents occur in mid-loop operation (i.e., because of the natural decay of the short-lived isotopes of iodine and tellurium, which are primarily associated with early health effects). The uncertainties in risk for accidents during mid-loop operations are largely due to uncertainties associated with isolating the containment and achieving a pressure retaining capability. 


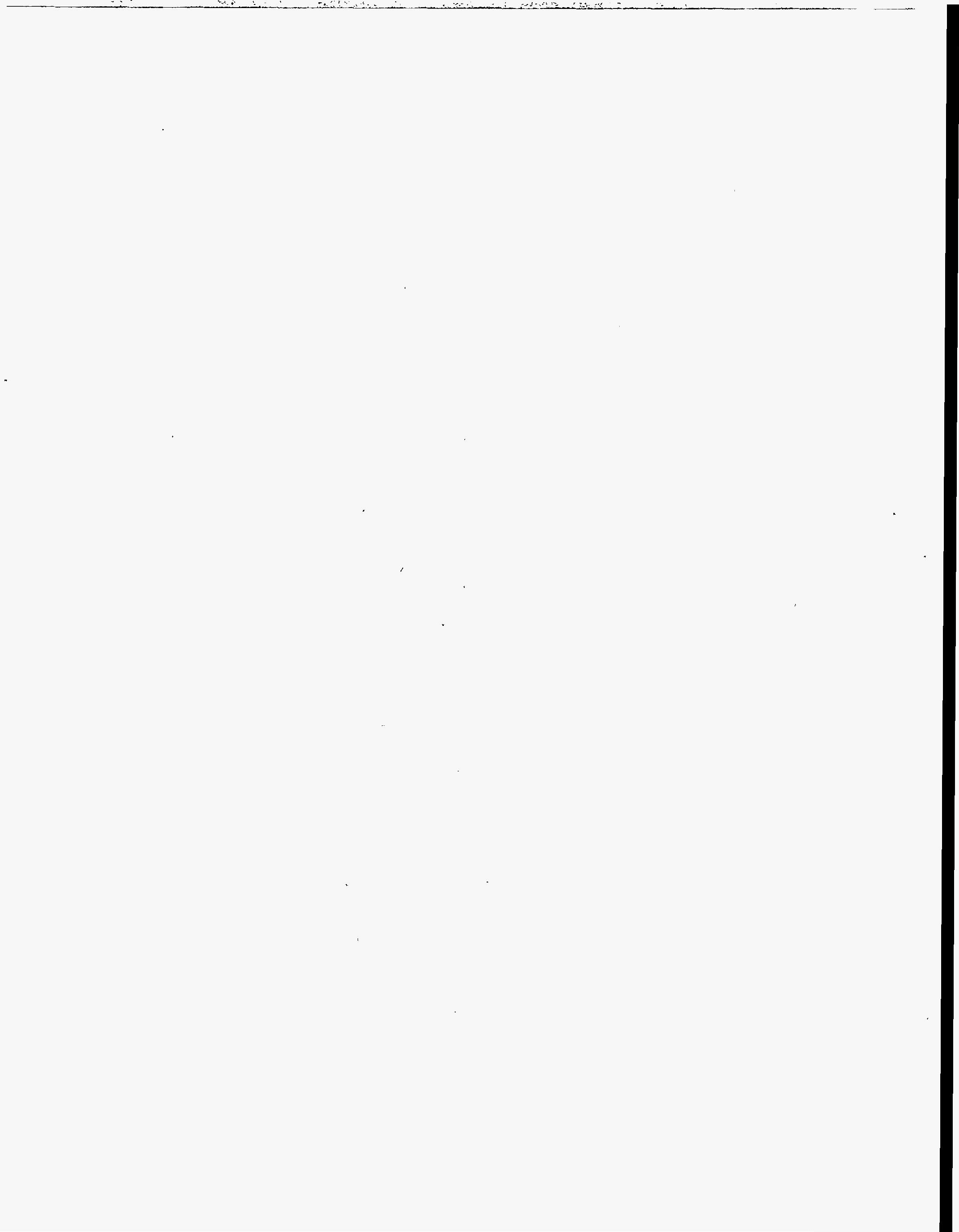




\section{CONTENTS}

Page

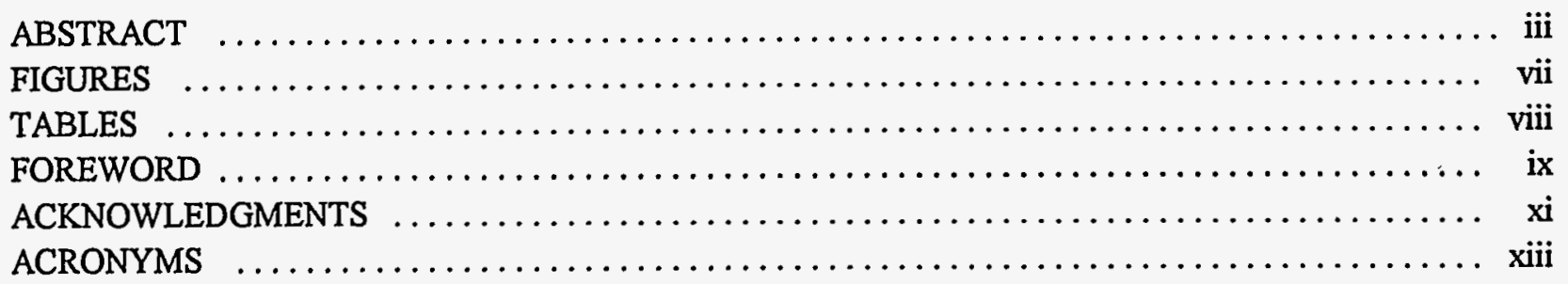

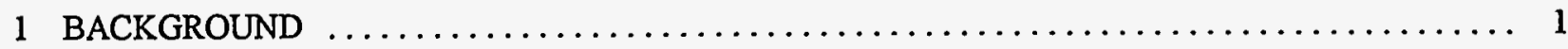

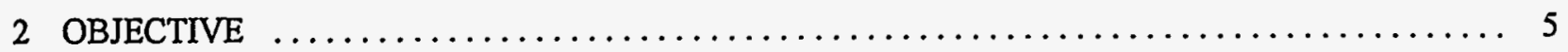

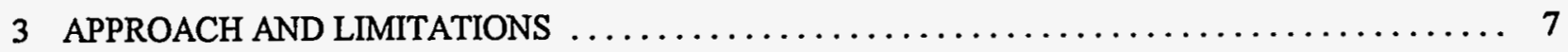

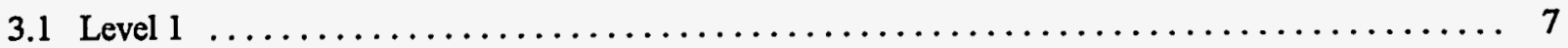

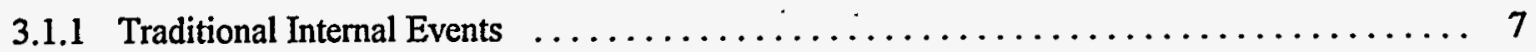

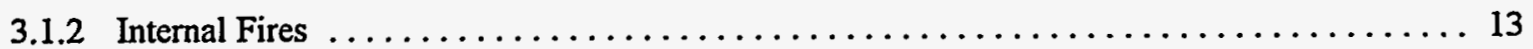

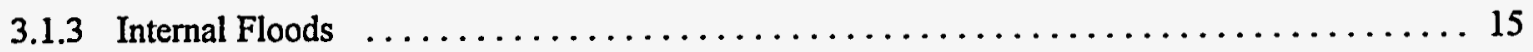

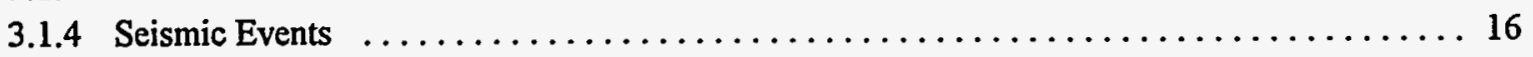

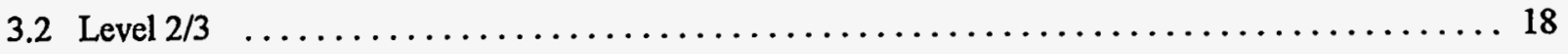

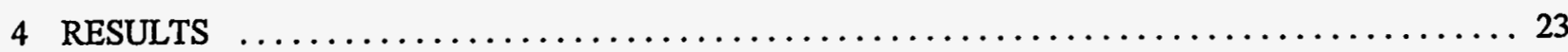

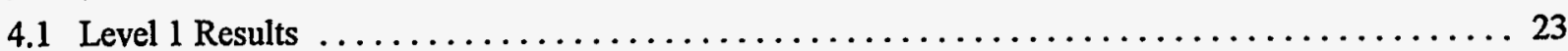

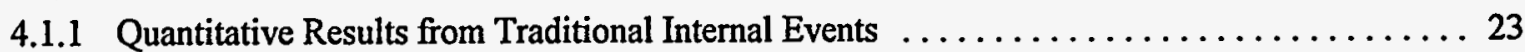

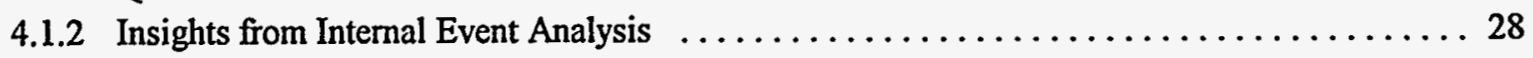

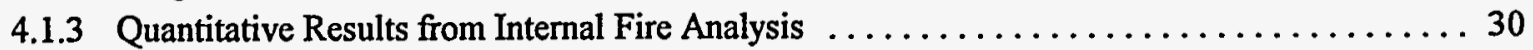

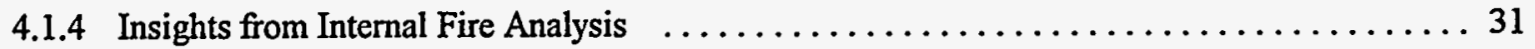

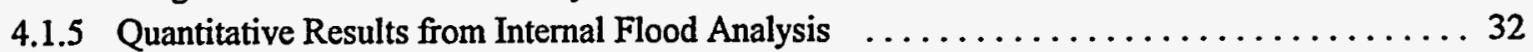

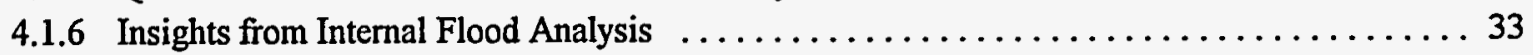

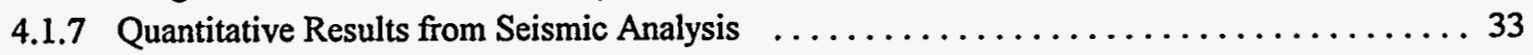

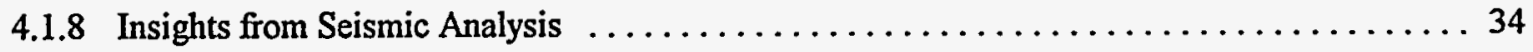

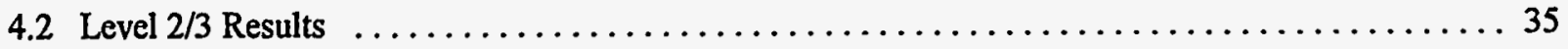

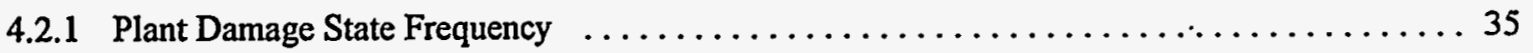

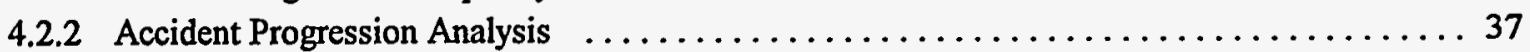

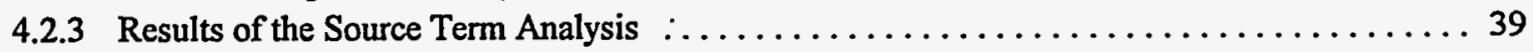

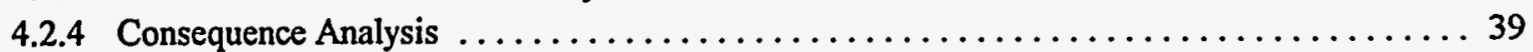

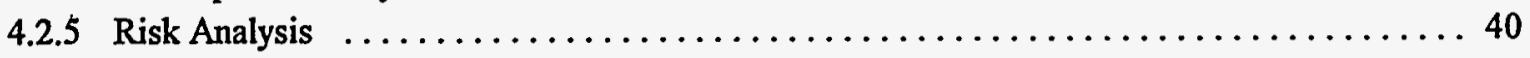

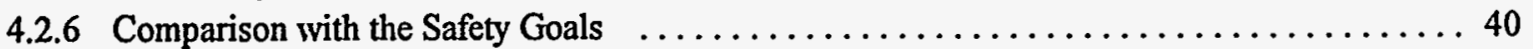

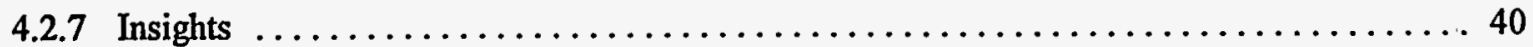




\section{CONTENTS (continued)}

\section{Page}

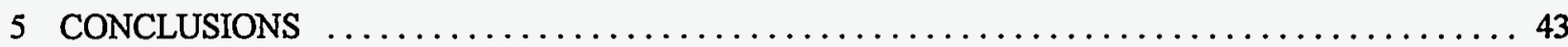

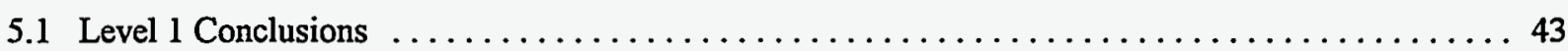

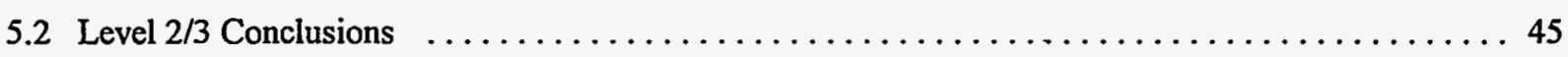

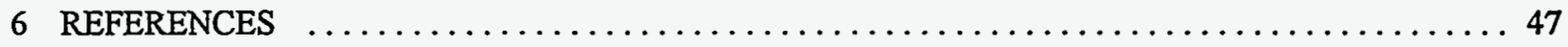

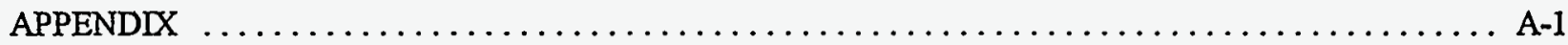




\section{FIGURES}

Page

1 Contribution of the 15 POSs to the total core damage frequency

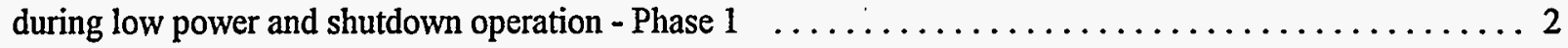

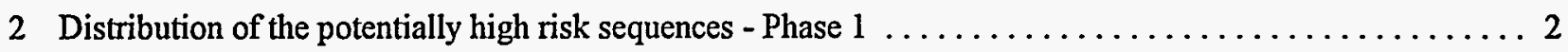




\section{TABLES}

1 Summary of Results: Core Damage Frequency by Initiating Event and Plant Operational States . . . . . 24

2 Comparison of Total Core Damage Frequency with NUREG-1150 and IPE $\ldots \ldots \ldots \ldots \ldots \ldots \ldots$

3 Conditional Core Damage Frequency as a Function of the Time Windows and POSs (per year) . . . . . 26

4 Result of the Level I Uncertainty Analysis and Comparison with Full Power Operation (per year) . . . . . 27

5 Summary of Point Estimate Core Damage Frequencies for Fire Events (per year) $\ldots \ldots \ldots \ldots \ldots \ldots 31$

6 Summary of Point Estimate Core Damage Frequencies for Flood Events (per year) $\ldots \ldots \ldots \ldots \ldots 32$

7 Comparison of the PDS Core Damage Frequencies (per reactor year) for Mid-Loop and Full-Power Operation (Internal Events Only) $\ldots \ldots \ldots \ldots \ldots \ldots \ldots \ldots \ldots \ldots \ldots$

8 Comparison of the Mean Probabilities of APBs Conditional on PDS Groups for Mid-Loop and Full-Power Operation (Internal Events Only) 38

9 Comparison of Distributions of Risks for Mid-Loop and Full-Power Operation (All Values per Reactor Year; Population Doses in P-Sv per Year) 


\section{FOREWORD}

\section{(NUREG/CR-6143 and 6144)}

\section{Low Power and Shutdown Probabilistic Risk Assessment Program}

Traditionally, probabilistic risk assessments (PRA) of severe accidents in nuclear power plants have considered initiating events potentially occurring only during full power operation. Some previous screening analysis that were performed for other modes of operation suggested that risks during those modes were small relative to full power operation. However, more recent studies and operational experience have implied that accidents during low power and shutdown could be significant contributors to risk.

During 1989, the Nuclear Regulatory Commission (NRC) initiated an extensive program to carefully examine the potential risks during low power and shutdown operations. The program includes two parallel projects performed by Brookhaven National Laboratory (BNL) and Sandia National Laboratories (SNL), with the seismic analysis performed by Future Resources Associates. Two plants, Surry (pressurized water reactor) and Grand Gulf (boiling water reactor), were selected as the plants to be studied.

The objectives of the program are to assess the risks of severe accidents due to internal events, internal fires, internal floods, and seismic events initiated during plant operational states other than full power operation and to compare the estimated core damage frequencies, important accident sequences and other qualitative and quantitative results with those accidents initiated during full power operation as assessed in NUREG-1150. The scope of the program includes that of a Level 3 PRA.

The results of the program are documented in two reports, NUREG/CR-6143 and 6144. The reports are organized as follows:

\section{For Grand Gulf:}

NUREG/CR-6143 - Evaluation of Potential Severe Accidents during Low Power and Shutdown Operations at Grand Gulf, Unit 1

Volume 1: Summary of Results

Volume 2: Analysis of Core Damage Frequency from Internal Events for Operational State 5 During a Refueling Outage

Part 1: Main Report

Part 1A: Sections 1 - 9

Part 1B: Section 10

Part 1C: Sections $11-14$

Part 2: Internal Events Appendices $A$ to $H$

Part 3: Internal Events Appendices I and $J$

Part 4: Internal Events Appendices $\mathrm{K}$ to $\mathrm{M}$

Vol. 1 


\section{FOREWORD (continued)}

Volume 3: Analysis of Core Damage Frequency from Internal Fire Events for Plant Operational State 5 During a Refueling Outage

Volume 4: Analysis of Core Damage Frequency from Internal Flooding Events for Plant Operational State 5 During a Refueling Outage

Volume 5: Analysis of Core Damage Frequency from Seismic Events for Plant Operational State 5 During a Refueling Outage

Volume 6: Evaluation of Severe Accident Risks for Plant Operational State 5 During a Refueling Outage

Part 1: Main Report

Part 2: Supporting MELCOR Calculations

For Surry:

NUREG/CR-6144 - Evaluation of Potential Severe Accidents during Low Power and Shutdown Operations at Surry, Unit-1

Volume 1: Summary of Results

Volume 2: Analysis of Core Damage Frequency from Internal Events during Mid-loop Operations

Part 1: Main Report

Part 1A: Chapters 1 - 6

Part 1B: Chapters $7-12$

Part 2: Internal Events Appendices A to D

Part 3: Internal Events Appendix E

Part 3A: Sections E.1 - E.8

Part 3B: Sections E.9 - E.16

Part 4: Internal Events Appendices $F$ to $H$

Part 5: Internal Events Appendix I

Volume 3: Analysis of Core Damage Frequency from Internal Fires during Mid-loop Operations

Part 1: Main Report

Part 2: Appendices

Volume 4: Analysis of Core Damage Frequency from Internal Floods during Mid-loop Operations

Volume 5: Analysis of Core Damage Frequency from Seismic Events during Mid-loop Operations

Volume 6: Evaluation of Severe Accident Risks during Mid-loop Operations Part 1: Main Report

Part 2: Appendices 


\section{ACKNOWLEDGMENTS}

The authors wish to thank the following persons for their contributions to this study: the various staff members at the Surry Nuclear Power Plant for their help in obtaining technical information and for their assistance during the respective walkdowns (fire, flood, and seismic,) all of which made this analysis possible; Richard C. Robinson, Jr. of the NRC for his help and guidance throughout the course of this study. Kenneth Russell of Idaho Nuclear Engineering Laboratory for his help in using IRRAS and for providing excellent code support during its use; and members of the Senior Consulting Group for their review and suggested improvements to the project. Finally, we want to thank Kathy Ryan and Barbara Kponou for their patience and secretarial support, and Cheryl Conrad for her technical support throughout the course of this study. 



\section{ACRONYMS}

Acronym

Definition

$\begin{array}{ll}\text { ADHR } & \text { Auxiliary Decay Heat Removal system } \\ \text { APB } & \text { Accident Progression Bin } \\ \text { APET } & \text { Accident Progression Event Tree } \\ \text { ASEP } & \text { Accident Sequence Evaluation Program } \\ \text { ATWS } & \text { Anticipated Transient Without Scram } \\ \text { BNL } & \text { Brookhaven National Laboratory } \\ \text { BWR } & \text { Boiling Water Reactor } \\ \text { CCW } & \text { Component Cooling Water } \\ \text { CDF } & \text { Core Damage Frequency } \\ \text { CS } & \text { Containment Spray } \\ \text { CSD } & \text { Cold Shutdown } \\ \text { CVCS } & \text { Chemical and Volume Control System } \\ \text { CVT } & \text { Cable Vault and Tunnel } \\ \text { CW } & \text { Circulating Water } \\ \text { EF } & \text { Error Factor } \\ \text { EPRI } & \text { Electric Power Research Institute } \\ \text { ESGR } & \text { Emergency Switchgear Room } \\ \text { FMEA } & \text { Failure Mode and Effect Analysis } \\ \text { HAZOP } & \text { Hazard and Operability Study } \\ \text { HEP } & \text { Human Error Probability } \\ \text { HHSI } & \text { High Head Safety Injection } \\ \text { HRA } & \text { Human Reliability Analysis } \\ \text { HSD } & \text { Hot Shutdown } \\ \text { INEL } & \text { Idaho National Engineering Laboratory } \\ \text { IPE } & \text { Individual Plant Examination } \\ \text { IPEEE } & \text { Individual Plant Examination of External Events } \\ \text { IRRAS } & \text { Integrated Reliability and Risk Analysis System } \\ \text { ISLOCA } & \text { Interfacing Systems LOCA } \\ \text { LLNL } & \text { Lawrence Livermore National Laboratory } \\ \text { LER } & \text { Licensee Event Report } \\ \text { LHS } & \text { Latin Hypercube Sampling } \\ \text { LOCA } & \text { Loss of Coolant Accident } \\ \text { LOOP } & \text { Loss of Offsite Power } \\ \text { LPCI } & \text { Low Pressure Coolant Injection system } \\ \text { LP\&S } & \text { Low Power and Shutdown } \\ \text { LPCS } & \text { Low Pressure Core Spray system } \\ \text { MCC } & \text { Motor Control Center } \\ \text { MFW } & \text { Main Feedwater } \\ \text { MW } & \text { Megawatt } \\ \text { NRC } & \text { Nuclear Regulatory Commission } \\ \text { PDS } & \text { Plant Damage State } \\ \text { PORV } & \text { Pilot Operated Relief Valve } \\ \text { POS } & \text { Plant Operational State } \\ \text { PRA } & \text { Probabilistic Risk Assessment } \\ \text { PRZR } & \text { Pressurizer } \\ & \end{array}$

Vol. 1 


\section{Acronyms (continued)}

Acronym

PSF

PSIG

PWR

RCIC

$\mathrm{RCP}$

RCS

RHR

RPS

RPV

RSS

RWCU

RWST

SDC

SG

SGTR

SNL

SV

SW

TS
Definition

Performance Shaping Factor

Pound Per Square Inch Gauge

Pressurized Water Reactor

Reactor Core Isolation Cooling system

Reactor Coolant Pump

Reactor Coolant System

Residual Heat Removal

Reactor Protection System

Reactor Pressure Vessel

Reactor Safety Study (WASH-1400)

Reactor Water Cleanup system

Refueling Water Storage Tank

Shutdown Cooling

Steam Generator

Steam Generator Tube Rupture

Sandia National Laboratories

Safety Valve

Service Water

Technical Specification 


\section{BACKGROUND}

Traditionally, probabilistic risk assessments (PRA) of severe accidents in nuclear power plants have considered initiating events (IEs) potentially occurring only during full power operation. Some previous screening analyses that were performed for other modes of operation suggested that risks during those modes were small relative to full power operation. However, more recent studies and operational experience have implied that accidents during low power and shutdown could be significant contributors to risk.

During 1989, the Nuclear Regulatory Commission (NRC) initiated an extensive program to carefully examine the potential risks during low power and shutdown operations. The program includes two parallel projects being performed by Brookhaven National Laboratory (BNL) and Sandia National Laboratories (SNL). Two plants, Surry (pressurized water reactor) and Grand Gulf (boiling water reactor), were selected as the plants to be studied.

Surry Unit 1 was chosen for this study in part because the Surry plant was previously analyzed in the Reactor Safety Study ${ }^{[1]}$ and NUREG-1150, ${ }^{[2]}$ and in part because Virginia Power offered to cooperate. The core damage frequency (CDF) during low power and shutdown calculated in this study is compared with that calculated in NUREG-1150 for accidents during full power. The Surry plant has two Pressurized Water Reactors (PWRs), each rated at 788 megawatts (electrical) capacity, and is located near Surry in Virginia. Grand Gulf, a boiling water reactor, was selected as the plant for a parallel analysis performed by Sandia National Laboratories.

A phased approach was taken in this project. In Phase 1 , a broadly scoped screening analysis, ${ }^{[3]}$ which included internal fire, flood, and seismic events was completed in late 1991. The objective of the Phase 1 study was to identify potential vulnerable plant configurations, to characterize (on a high, medium, or low CDF basis) the potential core damage accident scenarios, and to provide a foundation for a detailed Phase 2 analysis. This analysis produced a preliminary Level 1 PRA for accidents initiated during low power and shutdown (LP\&S) and also gave insights on potential accident scenarios and potentially vulnerable configurations during low power and shutdown conditions.

In Phase 1, plant outages were grouped into 4 outage types: refueling, drained maintenance, non-drained maintenance with use of the residual heat removal (RHR) system, and non-drained maintenance without the RHR system. Due to the continuously changing plant configuration in any outage, plant operational states (POSs) were defined and characterized within each outage type. Each POS represents a unique set of operating conditions (e.g., temperature, pressure, and configuration). For example, in a refueling outage, up to 15 POSs were used, representing the evolution of the plant throughout a refueling from low power down to cold shutdown and refueling, and back-up to low power. An extensive effort was made to collect Surry-specific data to characterize each POS, that included reviewing operating and abnormal procedures for shutdown operations, the shift supervisor's log books, and the monthly operating reports, and performing supporting thermal-hydraulic calculations.

The Phase 1 study analyzed a total of 947 accident sequences or scenarios. Each of them was quantified and ranked according to the CDF of the scenario, timing of onset of core damage, and containment status. Figures 1 and 2 summarize the results of the quantification. Figure 1 shows the contribution of the 15 POSs to the total core damage frequency during low power and shutdown operation. POS 12, representing a cold shutdown condition late in a refueling outage, has the highest core damage frequency. This is due to high maintenance unavailabilities of equipment needed to mitigate an accident and conservatism introduced by the simplified model. Figure 2 shows the

Vol. 1

NUREG/CR-6144 
1 Background

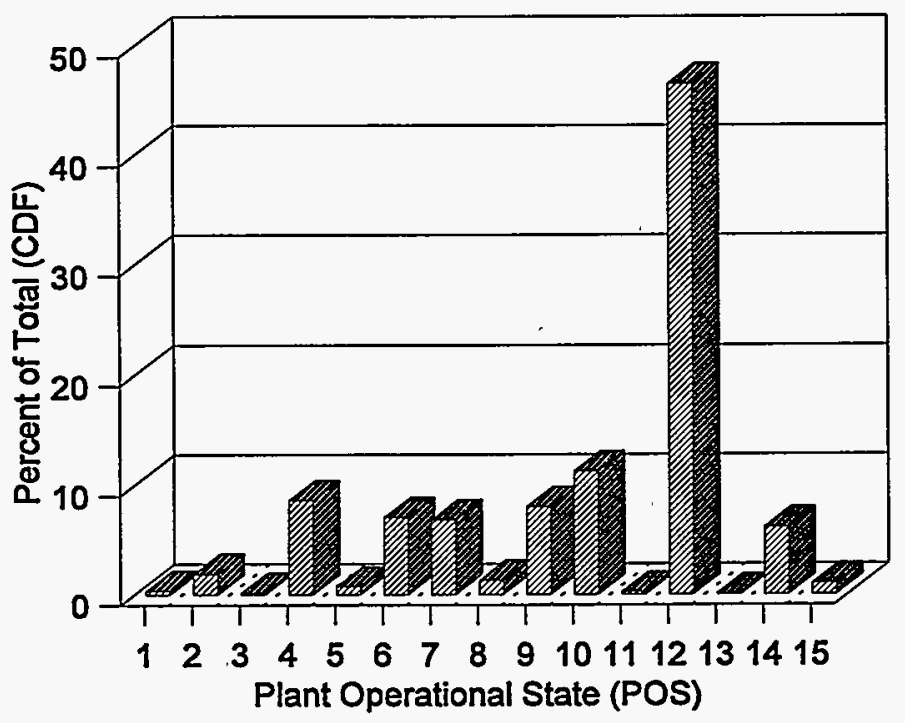

Figure 1 Contribution of the 15 POSs to the total core damage frequency during low power and shutdown operation - Phase 1

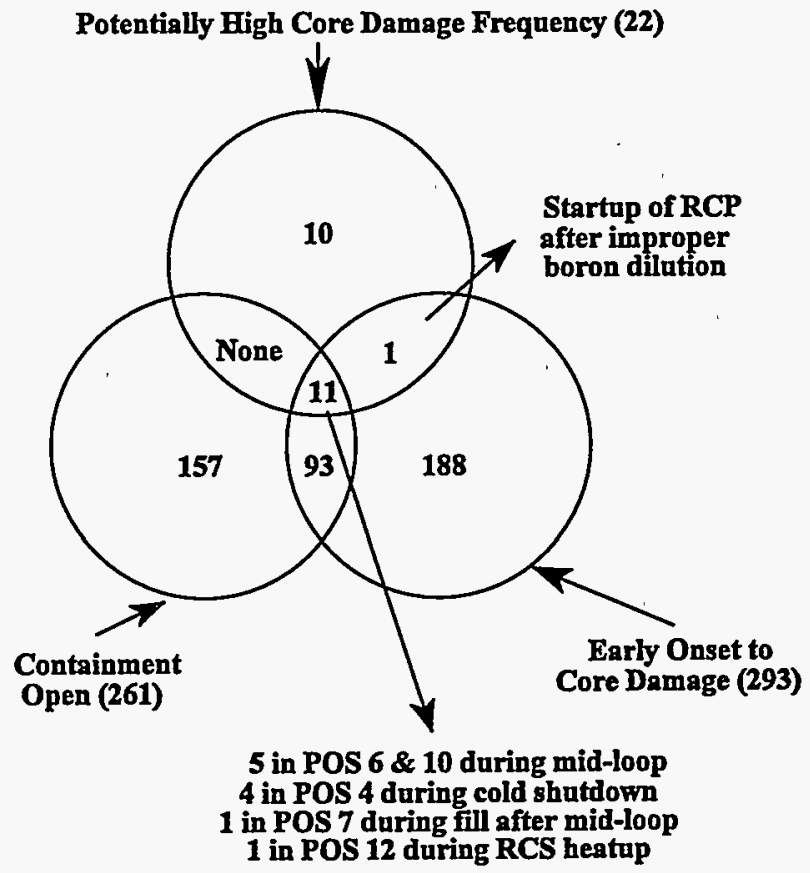

Figure 2 Distribution of the potentially high risk sequences -.Phase 1 
distribution of the 460 potentially high risk sequences. A total of 11 sequences were found to have high frequency with early core damage when the containment is open, and 5 out of the 11 sequences occur during mid-loop operation.

To accurately address each of the conditions identified in the Phase 1 study in detail would represent a very large effort. Consequently, the NRC decided to perform a detailed Phase 2 analysis on mid-loop operation. This configuration was selected because many incidents have occurred during mid-loop operations throughout the world. In addition, recent studies, ${ }^{[4]}$ including Phase 1 of this program, found that the core damage frequency during midloop operation appears to be comparable to that of power operation. The Phase 2 internal event analysis is documented in Volume 2 of this report. The internal fire and internal flood analysis are documented in Volumes 3 and 4, respectively. A separate study on seismic analysis, documented in Volume 5, was performed for the NRC by Future Resources Associated, Inc.

A phased approach was also used in the Level $2 / 3$ program and both phases addressed the risk from only mid-loop operation. The first phase of the Level 2/3 PRA was initiated in late 1991 and consisted of an Abridged Risk Study. This study was completed in May 1992 and was focused on accident progression and consequences, conditional on core damage. Phase 2 is a more detailed study in which an evaluation of risk during mid-loop operation was performed. The results of the Phase 2 Level 2/3 study are the subject of Volume 6.

This volume of the report summarizes information contained in the documentation of the detailed analyses (refer to Volumes 2 through 6 of NUREG/CR-6144) performed for the Surry plant during mid-loop operation. A companion project for the Grand Gulf plant (a BWR) during cold shutdown was conducted by Sandia National Laboratories and is documented in NUREG/CR-6143. [5] $^{[3}$ 



\section{OBJECTIVE}

The primary objective of this study was to perform a detailed analysis of potential accidents that could occur at Surry while the plant is in mid-loop operation. The initiating events to be examined included: (1) internal initiators including fire and flood, and (2) seismic initiators.

The objectives of the Level 1 study are:

(1) Estimate the frequencies of severe accidents that might be initiated during mid-loop operation,

(2) Compare the estimated core damage frequencies, important accident sequences, and other qualitative and quantitative results of this study with those of accidents initiated during full power operation (as assessed in NUREG-1150), and

(3) Demonstrate methodologies for accident sequence analysis for plants in modes of operation other than full power.

The objectives of the Level $2 / 3$ study are:

(1) Develop methods to compute the risk of the Surry plant during mid-loop operation and perform the study, utilizing to the extent possible the component analyses developed as part of the NUREG-1150 program,

(2) Identify those factors that have the most impact on the risk estimates and highlight unique features of the risk analysis performed, and

(3) Compare the results of the study against the risk of full power operation as evaluated in the NUREG-1150 study of Surry and the NRC safety goals. 



\section{APPROACH AND LIMITATIONS}

Due to the changing plant configuration during low power and shutdown operation, it was necessary to define different outage types, and different plant operational states (POSs) within each outage type. Within each POS, the plant configuration continues to change with time, and the decay heat continues to decrease. These factors significantly affect scenario frequencies. Therefore, a "time window" approach was developed in which different time windows were defined representing different levels of decay heat and success criteria. Within each time window, the approach used in performing the PRA for a particular POS in a particular outage type is similar to that used in the NUREG-1150 study. The following is a summary of the approach used in the key tasks of this study. The approach can be readily adopted for studies of POSs other than mid-loop and for other PWRs. The key assumptions are discussed at the end of each subsection. A more detailed description of approaches that can be used to perform a Level 1 low power and shutdown PRA is given in an Appendix to this report.

\subsection{Level 1}

\subsubsection{Traditional Internal Events}

\section{Outage Types, Plant Operational States and Time Windows}

The outage types and POSs defined in Phase 1 of this study were also adopted in Phase 2. Three mid-loop POSs, in which the reactor coolant system (RCS) level is lowered to the mid-plane of the hot leg, were selected for detailed analysis. Two of them occur in a refueling outage, POSs R6 and R10, and one in a drained maintenance outage, POS D6. The states are characterized by different levels of decay heat, and different plant configurations, such as the number of RCS loops that are isolated, and whether or not the RCS has a large vent. R6 represents a mid-loop operation that takes place early in a refueling outage allowing the RCS loops to drain quickly to permit eddy current testing of the steam generator tubes. R10 takes place after the refueling operation is completed to allow additional maintenance of equipment in the RCS loops. D6 represents mid-loop operation in which maintenance activities require the plant to go to mid-loop, and is characterized by the highest level of decay heat among the three mid-loop POSs.

To more accurately define the decay heat level when an accident is initiated, a time-window approach was developed. Four time windows after shutdown were defined, each with a unique set of success criteria reflecting the decay-heat level. For POSs R6 and D6, all four windows were needed. For POS R10, only time windows 3 and 4 were applicable. A statistical analysis was made on the time to and duration of mid-loop to determine the probability that a given accident occurs in a particular time window, conditional on the accident occurring. In this approach, an event tree was developed for each accident initiating event, POS and time window. One hundred and sixty event trees were developed for 16 initiating events.

During the Surry Unit 1 refueling outage that started on February 28, 1992, the utility changed previous practice and avoided going to mid-loop operation. Although the plant staff intend to continue this new practice mid-loop operation cannot be totally avoided in the future. Therefore, with NRC concurrence, BNL developed the PRA model 
based on outages (that included mid-loop operation) before the February 1992 refueling. Since the results are also presented on a per-unit-time basis, the results can be used to draw conclusions on the management of mid-loop outages.

\section{Initiating Event Analysis}

To identify initiating events, the existing studies, licensee event reports, (LERs), published NRC documents, and current Surry operating procedures were reviewed. This approach should ensure that any incident that has occurred or any scenario that has been studied will be considered in the present study. However, a systematic approach, such as a failure mode and effect analysis (FMEA) or a hazard and operability study (HAZOP), to further assure that all possible initiating events in all possible operating states were identified was not performed.

\section{Event Tree Analysis}

In Phase 1 of this study, accident scenarios were developed for all Low Power and Shutdown POSs. For those POSs that are similar to power operations, (e.g., low power operations), the relevant NUREG-1150 event trees developed for Surry were reviewed and modified (if necessary) to reflect the current plant design and operation. For other POSs, event trees were developed in group discussions, involving typically four or more BNL staff members with expertise in PWR operations, PRA, human reliability analysis (HRA), and thermal-hydraulics. Communications with the staff at Virginia Power clarified questions on the plant's design and operations.

In Phase 2, the event trees developed for the mid-loop POSs were reviewed and modified to incorporate additional information obtained in the system analysis, and to reflect current understanding of the expected operator responses to the accidents. A two-day meeting with Virginia Power operations personnel was held to discuss potential accident scenarios, and the expected responses of the plant and operators.

\section{System Analysis}

The fault tree models, developed as part of NUREG-1150 study, were reviewed and modified (when necessary) to develop two fault tree models for the plant applicable to shutdown and to low power operation for each system. The system configuration during shutdown was identified by reviewing the operating procedures used during shutdown, shift supervisor's log books, and the system training manual.

\section{Definition of Core Damage}

In the NUREG-1150 study, core damage was defined to be when the RCS level reached the top of active fuel. Due to relatively high decay heat levels, the difference between this time and the time of cladding failure is small. Under low power and shutdown conditions, the decay heat level will be significantly lower, and therefore, the difference between these two times becomes more significant. In this study, core damage was therefore defined to be the collapsed RCS level reaching 2.5 feet above the bottom of the core. This is based on the result of a MELCOR calculation of the RCS level in the core region when the cladding temperature reaches $1340^{\circ} \mathrm{F}$. Phenomena such as clad oxidation and ballooning have an impact on core behavior above $1340^{\circ} \mathrm{F}$. Time to core damage is used in the Level 1 study to determine the time available for operator actions such as initiating safety injection. The more realistic estimate of the time available has the tendency of lowering the associated human error probabilities. 


\section{Supporting Thermal-Hydraulic Analysis}

The main purpose of the thermal-hydraulic analysis was to support the development of event trees and quantification of accident sequences. Thermal-hydraulic considerations are the basis of the time-window approach. Basically, the time windows were defined by the times when the success criteria of important mitigating functions change significantly.

In the Phase 1 study, assumptions were made based on simple "back of the envelope" calculations. It was found that more detailed calculations were needed to confirm the simple calculations, and support the assumptions made. In the Phase 2 study, a more detailed calculation was done to determine the timing of a feed and bleed operation during midloop operation. The calculation also gave information on the amount of water from the refueling water storage tank (RWST) needed to sustain the feed and bleed operation, as well as the timing of core uncovery for different initial conditions.

The MELCOR code ${ }^{[6]}$ was used to assess whether or not gravity feed from the RWST could be used to provide long term cooling (i.e., 24 hour decay heat removal). It was found that although gravity feed is sufficient only when the decay heat is low, it can buy a few hours for restoring other means of removing decay heat even when the decay heat is high.

For reflux cooling, the studies at the Idaho National Engineering Laboratory (INEL), ${ }^{[7],[8]}$ Westinghouse ${ }^{[9]}$ and Virginia Power ${ }^{[10]}$ were used to determine the success criteria. The analysis of feed and spill, gravity feed and reflux cooling were used to determine the boundary of the time windows.

\section{Quantification}

A Bayesian approach ${ }^{[11]}$ was used to estimate the initiating event frequencies. The basic event data for hardware failures were derived from the NUREG-1150 data base for Surry. The IRRAS computer code ${ }^{[12]}$ was used to quantify the fault tree and event tree, with a truncation limit of $10^{-10}$. An uncertainty analysis of the total core damage frequency was performed by propagating the uncertainty of the parameters used in the model.

\section{Human Reliability Analysis}

Two types of human error events were identified and modeled in this study: pre- and post-accident errors. The preaccident errors identified in the full power study for Surry ${ }^{2}$ were adopted, together with others identified in the system analysis task and added to the system fault trees.

To evaluate human actions and recovery actions that follow an initiator, the event scenario, required actions, important factors affecting operator performance, and the consequences of the action being unsuccessful were qualitatively defined. Two types of post accident human errors were modeled, failure to diagnose and failure to carry out the needed action given successful diagnosis. They were used in the fault trees for the top events of the event trees. It was assumed that, given failure to diagnose, the operator would fail to perform the needed actions; therefore, core damage would result. The same basic event representing failure to diagnose was used in all fault trees for a given event tree. On the other hand, failure to carry out the action given successful diagnosis would only fail the specific top event of the event tree. 


\section{Approach and Limitations}

The qualitative evaluation of the actions and the important parameters that affect operator's performance were used to derive the human error probabilities (HEPs) by adapting the success likelihood index methodology. ${ }^{[13]}$ This methodology ${ }^{[14]}$ assumes that the likelihood of operator error in a particular situation depends on the combined effects of a small set of performance-shaping factors (PSFs) that influence the operator's ability to accomplish the action.

To quantify the HEPs, the PSFs were rated with weights that reflect the relative influence of each PSF on the likelihood of the success of the action, and a score that reflects whether the PSF helps or hinders the operator in carrying out the actions. With the rating for PSF, the numerical model was calibrated using well defined actions obtained from analysis for other PRAs. Calibration ensures that the error probabilities are realistic and consistent with the data, observed human behavior, and the results from comparable expert evaluations of similar activities.

\section{Data Base Analysis}

An extensive effort was devoted to collecting data to characterize the plant during shutdown.

(1). A data base of initiating events was compiled for the initiating event analysis.

(2) The shift supervisor's log books, outage schedules, minimum equipment list, and monthly operating reports were reviewed to collect the data needed to estimate the frequency of shutdown, duration of plant operational states, and maintenance unavailabilities.

(3) The shift supervisor's log books were reviewed to determine the time that the plant is in different configurations. For example, the reactor coolant loops were found to be isolated for a long period in a refueling.

\section{Key Assumptions:}

The following is a discussion of the various modeling issues and how they were treated.

\section{Changing Plant Practices and Information}

Staff at the Surry plant are aware of the potential safety concerns of reduced inventory operations and they are constantly making improvements regarding such operations. This is reflected in improvements in the operating procedures and abnormal procedures used during shutdown, as well as changes in plant practice. The most significant change in plant practice started in the refueling outage of Unit 1 in 1992, during which mid-loop operation was totally avoided; this appears to be the new policy. Another way of reducing the risk is to carry out reduced inventory operation while the fuel in the core is removed during refueling.

Modifications made to the model developed for this study account for procedures and other plant information available as of April 30,1993. Regarding the plant's policy of avoiding mid-loop operation, it was decided that this study would use the data collected from past outages before the Unit 1 refueling outage of 1992 . Consequently, the core damage frequency reported in this study could be overestimated by making this assumption. However, it is emphasized that the core damage frequency calculated in the current study was reduced significantly by changes made before April 1, 1993. 


\section{Changing Plant Configuration}

Due to the activities taking place during shutdown, the plant configuration changes with time, which affects the likelihood of initiating events and the ability to mitigate the accidents. In this study, the constantly changing plant configuration was approximated by a number of discrete configurations, namely: different outage types, POSs, and time windows. The changing configuration was also reflected by the different basic events and different event trees for each of these configurations. The following is a description of the basic events and how they varied.

\section{Initiating Event Frequency}

The initiating events were assumed to occur with constant rates independent of the outage type or POS. The conditional probability that an initiating event occurs in a POS was calculated as the product of the rate and the duration of the POS. The initiating event frequency is the frequency of the POS multiplied by the conditional probability. The frequency that it occurs in a given time window of a given POS of a given outage type is the initiating event frequency times the conditional probability of the time window of the given POS.

\section{Loop Isolation Probability}

Isolating the loops makes it impossible to establish reflux cooling. Loop isolation probability was estimated by judgment using the information from the log books for outages, and an outage plan for a refueling outage. It was estimated as a function of the outage types, and time windows.

\section{Removal of Pressurizer Safety Valves}

The fraction of time that the safety valves are removed in a given time window of a given POS in a given outage type was estimated by judgment, using information from the log books for outages, and an outage plan for a refueling outage. With the safety valves removed, it is possible to use gravity feed from the RWST, but not reflux cooling because of inventory loss through the opening.

\section{Maintenance Unavailabilities}

Maintenance unavailability was estimated as a function of the POSs of a refueling outage by reviewing the log books for three refueling outages. The data was collected for the period when the plant was at mid-loop. Due to lack of sufficient information, it was assumed to be independent of the time windows. It was also assumed that the data for a refueling outage is applicable to a drained maintenance outage.

\section{Success Criteria}

The success criteria for shutdown conditions were determined by reviewing various studies, and performing supporting thermal-hydraulic analysis based on the Surry-specific design. The changing level of decay heat was accounted for by defining four time windows after shutdown, each with its own set of success criteria. In general, whenever the success criteria for one system or mitigating function changes, a new time window needs to be defined, and potentially, more than four time windows could be needed. The use of four windows, therefore, was a trade-off between the accuracy of the model and the level of effort needed to arrive at a solution. It was determined that four time windows give an adequate representation. 


\section{Approach and Limitations}

During development of the time window approach, it was recognized that the procedure for loss of RHR (AP-27.00) is conservative with respect to the success criteria for reflux cooling and feed-and-spill, and does not include all possible methods of establishing recirculation. These are the areas in which the plant model used in this study deviated from the abnormal procedure for the plant. The following describes how these issues were treated.

\section{Reflux Cooling}

In AP 27.00, the number of steam generators (SGs) needed for reflux cooling is given as a function of the decay heat (e.g., 3 SGs are needed for the first 75 hours after shutdown). This value is based on thermal-hydraulic considerations documented in a Virginia Power technical report. ${ }^{[10]}$ From a review of existing studies performed by $\operatorname{INEL}^{[7,8]}$ and Westinghouse ${ }^{[9]}$ on reflux cooling, and independent BNL calculations, it was determined that one steam generator is sufficient for reflux cooling. Therefore, based on more detailed calculations, it appears that one SG is sufficient, while the abnormal procedure states that three would be needed. The issue is, how much credit should be given to reflux cooling when less than three SGs are available. In this study, the conservative success criterion based on the procedure was used in the logic model, and whenever reflux cooling was failed due to insufficient SGs, a recovery action was entered with a failure probability of 0.1 .

\section{Feed-and-Spill}

In AP27.00 and its supporting study, ${ }^{[10]}$ the number of pumps and PORVs needed for this operation was determined based on the flow from the RWST needed to maintain sub-cooling, the capacity and shut-off head of the pumps, and the relieving capability of the PORVs. For example, during the first 129 hours after shutdown, 2 charging pumps and 2 PORVs would be needed. This success criterion was derived from the requirement to maintain sub-cooling, and is more stringent than the criterion needed for feed-and-bleed during an accident that occurs during full power operation. An alternative to feed-and-spill, (i.e., feed-and-steam), which is also discussed in reference [10], is much less demanding in terms of the needed flow. However, feed and steam is not the recommended method because of the difficulty in maintaining the level, and the potential for over pressurization. In this study, a success criterion of 1 charging pump and 1 PORV was used, based on the understanding that this is sufficient to prevent core damage.

\section{Recirculation}

AP 27.00 instructs the operators to establish high pressure recirculation by using the low-pressure injection pump to take suction from the containment sump, and discharge to the suction of the high pressure injection system: this requires that a low head injection pump and a charging pump are available. In the fault tree model for recirculation, two alternative methods also are modeled, low-pressure feed-and-steam (by taking suction from the containment sump), and low-pressure feed and spill (by taking suction from the sump and using spray recirculation). In these modes, low-head injection is needed. The feed-and-steam mode requires that the safety valves be removed to provide an adequate vent path, and does not require cooling of the sump water. The feed-and-spill operation requires operation of the spray recirculation systems to cool the water in the sump, so that sub-cooling in the reactor vessel can be established.

\section{Operator Response}

Operator actions modeled in this study were identified when developing the event trees. The identification process involved reviewing abnormal and emergency procedures, and discussing the accident scenarios with plant personnel. 
In most cases, the operator's responses to various accidents are identified in the procedures. For example, abnormal procedures for loss of RHR, loss of instrument air, and loss of offsite power give guidance on what to do in case of respective losses during shutdown. However, the latter two procedures are not written specifically for shutdown conditions. In case of a station blackout, the procedure written for power operation (1-ECA-0.0), does not address shutdown conditions. Therefore, only the relevant steps in the procedure are applicable to shutdown conditions. Similarly, for other initiating events, such as loss of component cooling, spurious safety injection, and loss of a vital bus, there is no specific procedure for shutdown conditions, and the ability of the operators to use the relevant steps in the procedures for power operation becomes very important. As discussed under success criteria, some of the operator actions modeled in this study are not explicitly spelled-out in the existing plant procedures, and some recovery actions modeled are extension of the existing procedures.

The operator actions needed to mitigate an accident are included in the high level fault trees. A high level fault tree models one method of mitigating the accident, e.g., feed-and-spill operation which typically contains two human error events, and one transfer to the fault tree for hardware failures. One human error event represents the failure of the operator to diagnose, so that the correct actions cannot be decided upon; the other represents failure to carry out the action after correct diagnosis. Assuming that the failure to diagnose would lead to core damage, many of the dominant core damage cutsets are caused by such events. Human error probabilities (HEPs) were quantified using the method of failure likelihood index that involves assessing weights and scores on various performance-shaping factors, and calibration using the HEPs from existing studies.

\subsubsection{Internal Fires}

\section{Fire Area Identification and Scenario Development}

Fire areas in which important equipment is located were identified. The areas are defined such that a fire in a certain location within the area might cause an initiating event by disrupting RHR operation. Cable routing information within the area was also included in the analysis (both for power and control cables) for important systems. Important systems were identified in the internal event PRA as providing alternate core cooling paths. Systems and components when damage by a fire could result in an initiator and possibly a degraded configuration of an alternate core cooling path. This information was eventually included in the event trees and fault trees developed for the internal event PRA. Whether or not a certain cable would be damaged by a fire in a certain location would be decided by the fire growth calculations. The probability of damage would be determined by the fire suppression model.

\section{Fire Frequency Calculations}

Fire frequency calculations were performed for important fire areas and for equipment found in these areas. Equipment classes were broken into subclasses (e.g., switchgear panels were divided up into bus panels, monitor control center (MCC) panels, un-interruptible power supply panels, etc.). Cable fires and transient fires were also considered. Large fires and small fires were calculated separately. Generic and Surry-specific fire events were obtained from the updated Sandia Fire data base, ${ }^{[15]}$ which considers events through 1989 . These events were used to calculate Surry specific fire frequencies in specific categories. These fire frequencies were then prorated to account for the fraction of fires in that category that can occur at a specific location. 
3 Approach and Limitations

\section{Fire Growth Modeling}

Once a certain critical location was identified (e.g., cables for important equipment pass nearby), the fire growth model was used to determine if a fire in that location would damage the cable (which may be located at a certain horizontal or vertical distance from the fire source). If damage does occur, the time to damage was also calculated. The model used for fire frequency calculations is the computer code COMPBRN-IIIe. ${ }^{[16]}$ While this model is an important advance in fire analysis the predications of the code remain uncertain because a number of aspects are not modeled well and simplifying assumptions have to be made. ${ }^{[16],[17]}$

\section{Fire Suppression and Damage Fraction Calculation •}

After fire initiation (and if detection occurs) suppression efforts will start to bring the fire under control. Detection and suppression may consist of combinations of manual and automatic systems. These systems may suppress the fire before damage to a critical cable occurs. (The time to damage is input from the fire growth calculations). The probability of damage in a certain scenario is the damage fraction, and is input as a basic event representing damage to the particular component in the PRA model, given the occurrence of a fire in that location. The suppression model uses transition rates among various states in the suppression path toward the eventual control of the fire. ${ }^{[18],[19],[20]}$ The transition rates and a particular combination of suppression steps determine the probability of suppression within a certain time and in the plant area that contains the detection and suppression equipment.

\section{Fault Tree and Event Tree Modifications}

The damage fraction calculated was input into the modified internal PRA model as a basic event representing a possible failure mode in a given component following a fire. The internal PRA model for a given initiator (caused by fire) was modified to account for additional equipment that may be damaged in a fire. Failure modes due to fire (e.g., spurious operation or power loss) were added to the internal failure modes of the component. The event tree shows core damage sequences given a fire in a certain location and given occurrence of the initiating event. The sequence frequencies were evaluated by IRRAS $5.0,{ }^{[12]}$ the computer program used in the internal PRA quantification.

Key Assumptions:

(1) Multiple initiators were not considered (e.g., loss of offsite power subsequent to a fire) for probabilistic reasons. For example, loss of offsite power probability in any 24 hour period is about $7 \mathrm{E}-4$ for the Surry plant at mid-loop. Multiplying this by the mid-loop time fraction of 0.066 means that the fire frequency at a given location would have to be a few times $10^{-3}$ in order for it to survive screening. No such scenarios were found.

(2) Barrier failure was not considered as it was determined to be probabilistically unimportant. For initiatorcausing fires that occur near an important barrier (very few examples were found), the combination of fire frequency, probability of equipment failures causing an initiator, the mid-loop POS fraction, and barrier failure probability (on the order of $\left.10^{-2}-10^{-3}\right)^{[17]}$ was such that the fire scenario frequency was below the screening value. Also, comparing this probability to the conditional core damage probability for most scenarios (0.1) leads to screening of this consideration. It should be noted that during the plant visits (including during shutdown), it was observed that all normally closed fire doors were kept closed. 
(3) Certain cables were not traced due to lack of resources and/or because the scenarios would be probabilistically unimportant, would not lead to an initiator, or would be an irrelevant post-initiator for the particular initiators possible in the fire area (various compressed air systems, diesel generator cables, ventilation system cables, etc.). In some instances assumptions were made regarding the location of these and other cables (i.e., cables in conduits for which no precise tracing system is available at Surry).

(4) It was assumed, for purposes of fire frequency calculations, that other plants are similar to Surry in terms of the amount of equipment of a certain type in the plant fire areas (e.g., number of switchgear cabinets in the emergency switchgear room).

(5) Relay fires were screened probabilistically, because the combination of a relay fire frequency, mid-loop fraction, and the conditional probability of initiator occurrence was below the screening value.

(6) It should be noted that both power and control cables were traced and spurious operation following hot shorts was treated. Lack of electrical coordination between the $4160 \mathrm{~V}$ emergency buses and the $480 \mathrm{~V}$ load centers was also taken into account.

\subsubsection{Internal Floods}

The approach used in the internal flood event analysis was based on approaches used in past PRAs, especially the methodology used in the full power study ${ }^{[2]}$ and the plant-specific Individual Plant Examination (IPE) ${ }^{[21],[22]}$ of the Surry plant. The basic steps in the analysis involve the following:

\section{Identification of Flood Areas Taking Into Consideration Spatial Interaction of Flood Areas}

In the Phase 1 study, ${ }^{[3]}$ a screening analysis was performed to identify the potential flood areas. These areas were used as the basis for the second phase effort. The potential pathways for flood propagation were identified using the information obtained during a plant visit as well as information available from the NUREG-1150 and IPE studies. The spatial interactions and the various pathways between high risk areas (i.e., Turbine Building and Emergency Switchgear Room and Auxiliary Building) were inspected and evaluated for potential flood damage.

\section{Flood Event Frequency Analysis}

The initiating frequency data was developed based on actual flooding events and updated to include plant-specific features and data. The data was gathered from various sources including the IPE Surry flood analysis, industry sources, licensing event reports (LERs). In some cases, plant-specific models were developed especially with regard to the most important circulating water (CW) and service water (SW) lines in the Turbine Building. These two sources of flood dominate the risk, and therefore required special treatment. The most dominant failure mechanism for large pipes is pipe rupture due to water hammer events. Generic pipe failure data and models ${ }^{[23]}$ were used when plant-specific data was unavailable with the exception of the $\mathrm{CW}$ and $\mathrm{SW}$ lines. The effects of flood barriers and other mitigating mechanisms were also considered in the development of damage states.

The equipment damage due to internal flood was determined as a function of flood level. The flood level depends on various factors such as the leakage rate, area of interconnections, drainage pathways, and potential mitigating

Vol. 1 


\section{Approach and Limitations}

actions. In order to take these factors into account, simple flood damage categories or damage states were developed. The damage states effectively incorporate the time dependency of the flood event and any potential mitigating or recovery actions. The damage states reflect a particular flood-exceedance frequency at a particular location with a predefined equipment damage level. This allows the incorporation of any partial failures due to flooding or differentiation between equipment damages at a particular location.

The flood initiating frequencies were developed to incorporate simple recovery actions as expected from the existing experience or data base. In addition, the data base was examined for its applicability to the Surry plant and modified to take into account certain plant-specific features.

\section{Location and Scenario Identification}

The identification of potential accident scenarios and flood locations was accomplished by initially using the general arrangement diagrams and the RHR system fault tree developed for the internal event analysis. The fault tree identifies all equipment and support components required for the RHR system operation. These were located and identified on the plant drawings and correlated with the flood areas as identified during the analysis. The scenario development also included the identification of potential propagation pathways and their physical nature (doors, stairways, etc.) which may limit the flood rate. In addition, drainage potential and other mitigating features which could help in the recovery process were also identified. Once the flood scenarios were identified, the effect on other front line systems or their components was determined. This was limited to only those systems which were required to prevent core damage and were identified by examining the internal event trees for the loss of RHR function and/or station blackout. The appropriate equipment and/or its support were located and placed in the appropriate flood areas.

The quantification takes into account the rate of water flow into the area or height of the flood and establishes generally a critical flood level in each specific plant area. The time available for any recovery action was estimated by defining the critical volume and the applicable flow rate. This approach allows the incorporation of simple recovery actions in the quantification without greatly modifying the existing fault trees and internal event trees.

\section{Plant Response Analysis}

The internal flood analysis utilized the system fault trees and event trees developed for the internal event study. The flood events were categorized as to their effect on the residual heat removal system and were mapped to the corresponding event tree for internal events. The event trees were modified to take into account the specific accident evolution of the flood event. In addition, the system fault trees were also modified according to the effects of the flood on equipment used to mitigate the accident. The relevant human error probabilities were also modified as timing and potential spatial interactions complicated the accident progression.

\subsubsection{Seismic Events}

In this study, only a Level 1 seismic PRA was performed. The key elements are:

(1) Seismic hazard analysis - estimation of the frequency of various levels of seismic ground motion (acceleration) occurring at the site. 
(2) Seismic fragility evaluation - estimation of the conditional probabilities of structural or equipment failure for given levels of ground acceleration.

(3) Systems/accident sequence analysis - modeling of the various combinations of structural and equipment failures that could initiate and propagate a seismic core damage accident sequence.

(4) Evaluation of core damage frequency - assembly of the results of the seismic hazard, fragility, and systems analyses to estimate the frequencies of core damage for various accident sequences and for the plant as a whole.

\section{Key Assumptions:}

(1) The seismic study adopted all of the assumptions made in the internal events analysis without exception. Most importantly, the loss-of-offsite-power (LOOP) event trees were adopted directly. This included the definitions of the top events and underlying thermal-hydraulic and other assumptions that support these event trees, namely those corresponding to mid-loop operation.

(2) Only refueling outages were considered in this analysis. Indeed, only certain specific operating states within the standard refueling outages at Surry were considered. Outages for other reasons frequently occur at nuclear power plants, and they are of two broad types: controlled shutdowns and uncontrolled (rapid) shutdowns. Although these outages for other reasons can produce different plant operating states and configurations unique to the reason for the shutdown, resources in this analysis did not permit examining outage configurations other than those for refueling. In any event, refueling outages contribute a majority of the shutdown time.

(3) It was assumed that the only seismic events of concern are those that cause loss-of-offsite-power (LOOP) transients. Seismic events of lower acceleration than those causing LOOP are expected to have a negligible probability of causing severe plant accidents for two reasons: (i) Critical plant equipment, including the residual heat removal (RHR) system, can withstand significantly higher accelerations than that which is sufficient to cause LOOP. ${ }^{[24],[25]}$ Thus, loss of core-cooling capability will have a very low probability for seismic events too small to cause a LOOP. (ii) With offsite power available, sources of water sufficient to cool the core from alternative pumping sources will generally be available even if the RHR system fails.

(4) It was also assumed that a seismic-initiated LOOP is non-recoverable in the time frame of interest in this study (from about one to several hours). This is a reasonable and only slightly conservative assumption, because the LOOP initiator is most likely to arise from the seismic-caused failure of the ceramic insulators in the plant substation. ${ }^{[24,25]}$ Replacement of these insulators would likely require several hours at a minimum, and probably much longer. Additionally, other damage caused by the earthquake (for example, to offsite transmission systems and offsite switch yards) would likely hamper efforts to recover offsite power.

(5) The engineering methodology used to develop probabilistic seismic fragility curves employed a successivescreening approach, in which structures and equipment that are judged to be very strong under earthquake loading were screened out first. In this manner, the number of items for which actual numerical fragilities had to be developed was limited. Also, for a few items the study team was unable to obtain enough information, 
3 Approach and Limitations

either because access to some parts of the plant was limited or because engineering information in the appropriate form was not available. For these items, generic fragilities were used.

(6) The seismic failures of identical equipment in similar locations were assumed to be fully correlated. This means, for example, that when a postulated earthquake causes one diesel generator to fail, it was assumed that the other diesel generator(s) would also fail. This simplifying assumption is probably conservative in many cases, but perhaps not overly so for truly identical equipment. Sensitivity studies performed in several past seismic PRAs have shown that the bottom-line results are sensitive to this assumption at a level of about a factor of plus-or-minus two.

(7) Equipment failure from seismic-induced relay chatter is outside the scope of this analysis. While relay chatter can be important, ${ }^{[26]}$ it is a complicated issue, and the resources to study it were not available within this project. In any event, relay chatter is being studied at every U.S. nuclear plant as part of the current IPEEE program, ${ }^{[27]}$ and it is expected that almost all of the relays that are especially sensitive to relay chatter will be identified and, if appropriate, modified in the course of the IPEEE studies.

(8) Both the Lawrence Livermore National Laboratory (LLNL) ${ }^{[28]}$ and Electric Power Research Institute (EPRI) ${ }^{[29]}$ seismic hazard curves were used to produce two parallel results.

\subsection{Level $2 / 3$}

A phased approach was also used in the Level $2 / 3$ program; however, both phases addressed the risk from only midloop operation. The first phase of the Level 2/3 PRA was initiated in late 1991 and consisted of an Abridged Risk Study. This study focused on accident progression and consequences, conditional on core damage. Phase 2 is a more detailed study in which an integrated evaluation of risk due to internal events during mid-loop operation was performed. Risk estimates were not made for accidents initiated by internal fires, internal floods, and seismic events. As this study is limited to accidents during mid-loop operation, it is not a complete risk estimate for accidents that could occur during low power and shut down operation. The approach adopted in the Phase 2 study is mostly based on the NUREG-1150 approach. The sections below therefore describe only those elements of the methodology which are different from the NUREG-1150 approach.

\section{Accident Frequency Analysis}

The Level 1 analysis, including fault trees, event trees, recovery actions, etc., of the significant accident sequences leading to core damage and their frequencies, was carried out by the IRRAS code. ${ }^{[2]}$ A newly added feature of IRRAS which became available recently was used to group the minimal cut sets into the plant damage states (PDSs). Seven characteristics were used to construct the plant damage states.

The first characteristic identifies the time frame in which the accident occurs. A major difference between a PRA at full power and at mid-loop operation is the extended time period following shutdown during which an accident can occur. This time period allows for a significant decay of the power level, extends the time available for various phenomena and for recovery actions and leads to a lower value of the radionuclide inventory which can potentially be released. This feature of the shutdown PRA was modeled in the Level 1, accident frequency analysis through the 
construction of four "time windows" for various time periods following shutdown. Each time window has its own decay heat level and success criteria for accomplishing various recovery actions prior to core damage. The first PDS characteristic therefore identifies the time window in which the accident occurs.

The second characteristic provides the status of ac power. Of particular interest is whether or not ac power is available and if it is not available whether it can be recovered. Human error is an important contributor to the core damage accident frequency for mid-loop operation. The third characteristic therefore identifies if human error contributed to the accident and if it did what was the type of error. The status of the reactor coolant system can significantly impact accident progression and this is therefore addressed in the fourth PDS characteristic. For some plant damage states recovering coolant injection after the start of core damage can prevent further core damage and terminate the accident prior to the core melting through the reactor vessel. The fifth characteristic deals with the issue of restoring coolant injection. If core damage occurs and containment integrity is lost then operation of the containment sprays can reduce the airborne fission product aerosol concentration and reduce the amount of radionuclides released to the environment. The sixth characteristic gives the status of the spray system. Finally the status (injected or not injected) of the refueling water storage tank is given in the seventh characteristic.

Using the above characteristics, the Level 1 cutsets were binned into 48 plant damage states. These plant damage states were further binned into four PDS groups to be processed by the accident progression event tree (APET) analysis. The main consideration in binning was the similarity of accident progression after core damage.

PDS Group 1 consists of station blackout accidents.

PDS Group 2 consists of accidents attributable to human error.

PDS Group 3 consists of accidents in which core cooling is lost during recirculation.

PDS Group 4 consists of accidents where core cooling is lost because of loss of the $4 \mathrm{kV}$ bus.

\section{Accident Progression Analysis}

The accident progression event tree developed for mid-loop operation has been developed largely based on the APET developed for full power operation in the NUREG-1150 study. Some questions were removed and other questions pertinent to mid-loop operation (such as time windows and containment closure) were added. The APET for midloop operation consists of 40 questions compared to 71 questions in the full power APET. Due to resource limitations, a formal expert elicitation procedure could not be implemented to construct ranges of values and distributions for key variables. Assignments of these values and ranges were therefore made internally at BNL. The timing of key events in the accident progression is based on calculations carried out with the MELCOR code. ${ }^{[6]} \mathrm{A}$ very important issue which has a major impact on the result is the status of the containment at accident initiation. Assignments of the possible values of this status were made based on discussions and exchange of written communications with the Surry plant personnel. The APET was quantified using the EVNTRE ${ }^{[30]}$ code as in the full power study. It was again necessary to combine the numerous outcomes of the APET into accident progression bins (APBs) for input to the source term analysis. A similar approach to that used in the full power study was also used in the current analysis. The only additional information needed for the current study was the time window in which the accident occurred. Thus information identifying the time window was carried throughout all of the constituent analyses. 


\section{Approach and Limitations}

\section{Source Term Analysis}

The source term analysis used for mid-loop operation was similar to the approach used for full-power operation. The SURSOR $\left.{ }^{[31]}\right]$ code was reviewed for its applicability to shutdown conditions by an expert group consisting of staff from BNL and SNL. The source term ranges in SURSOR were also compared against predictions with the MELCOR code. In general SURSOR was considered appropriate for use in the current study. The APBs were therefore processed through the SURSOR code in a similar manner to the full power study. The output from SURSOR is a larger number of source terms which need to be grouped into representative source terms. The process was done in the full power study using PARTITION. ${ }^{[32]}$

Methodologically, the important difference between NUREG-1150 and the present study is a reworking of the partition approach to reflect the long time interval and consequent decay of the inventory in the current study. In effect, accident progression bins and source term groups are defined for each time window. The partitioning of the source terms and the assignment of health effect weights is carried out through a partition procedure designated PARTITION-LPS.

\section{Consequence Analysis}

The consequence measures for the average source term in each source term group were calculated by the MACCS code. ${ }^{[33]}$ The latest release of MACCS, Version 1.5.11.1, which incorporates the important BEIR V update to the latent cancer-dose relationship, ${ }^{[34]}$ was used to compute consequences. In contrast, the NUREG-1150 study used an earlier version of MACCS, Version 1.5.11, to compute consequences. The more recent version of MACCS gives a higher (by approximately a factor of 3) number of latent cancers, than the earlier MACCS version for the same value of population dose.

\section{Risk Integration and Uncertainty}

The integrated risk was obtained by combining the individual results of each of the constituent analyses. The approach was similar to the NUREG-1150 approach. Distributions were assigned to important variables (some distributions were identical to those used in NUREG-1150, others were developed specifically for mid-loop operation) and samples were then created by randomly picking values from the distributions using Latin Hypercube Sampling. ${ }^{[35]}$ For each sample the values assigned to each variable were propagated through the integrated analysis to determine risk estimates for each consequence measure. By repeating the calculation for 100 samples (or observations) distributions of risk estimates were obtained from which the uncertainty in risk was determined.

\section{Key Assumptions (Level 2/3 Study):}

(1) Discretization of time windows and decay heat levels: Decay heat level is a key parameter in the accident analysis due to the long time interval, depending on the POS and outage type, over which an accident can potentially occur during mid-loop operation. Four time windows with corresponding decay heat levels were constructed in the Level 1 analysis and it was assumed that the decay heat level (which varies continuously) of each time window can be adequately represented by its value at the mid-point of the time window.

(2) Containment Status: Several assumptions had to be made on the status of the containment during mid-loop operation. The pressure capability ranges from no pressure retaining capability (leakage at inception of release) 
to full design capability (as at full power operation). The ability of containment to retain fission products released from damaged fuel is the dominant factor affecting risk.

(3) Source Term: It was assumed that the source term code, SURSOR, which was developed for the full power study would adequately apply to low power and shutdown conditions as well. This assumption was checked through spot comparisons with calculations based on the mechanistic code MELCOR and by a review performed by a Source Term Advisory Group comprised of BNL and SNL staff.

(4) Consequences: The consequence calculation assumed the same emergency response for the offsite population in the low population zone surrounding Surry and the same long-term protective actions as the NUREG-1150 study.

(5) Onsite Doses: The scoping calculation of onsite doses assumed that the releases were directly from the containment to the environment through the equipment hatch and not through the personnel hatch so no inbuilding doses were calculated.

\section{Strengths and Limitations (Level 2/3 Study)}

The strengths of the Level $2 / 3$ study are:

(1) It is a systematic and integrated evaluation of risk during mid-loop operation at the Surry Unit 1 plant, including accident frequency, accident progression, source term and consequence analysis with a determination of uncertainty in each of the component analyses and in the final risk measures.

(2) The integrated analysis takes into account the long time after shutdown that the accidents can occur and the impact of the consequent decay in power level and radio nuclide inventory on the risk. In particular, new latent cancer weights were derived for source term partitioning and used in the consequence calculation.

(3) The newest version of the MELCOR code, Version 1.8.2, was used to calculate the timing of key events in the accident progression which were then used in the accident progression event tree.

(4) The accident progression event tree has sufficient detail to account for a significant portion of the likely paths of evolution of the accident.

(5) The study includes a scoping calculation of onsite dose rates at locations in the vicinity of the plant during the accident.

The Level $2 / 3$ study has the following main limitations:

(1) There was no formal expert elicitation process used, as in the NUREG-1150 study, to provide values and distributions for key variables in the accident progression. Assignments for these variables had to be made internally at BNL or derived from analogy with full power conditions. The selection of the key variables themselves was also made internally at BNL. Thus the uncertainty analysis is not as robust as it could have been with input from an expert panel. 
3 Approach and Limitations

(2) The scope of the Level 2/3 study is limited to accidents initiated by internal events (due to equipment failure or human error) during mid-loop operation. Risk estimates were not made for accidents initiated by internal fires, internal floods and seismic events. The final risk numbers should therefore not be interpreted to reflect the risk of all plant operational states during low power and shutdown operation. 


\section{RESULTS}

\subsection{Level 1 Results}

\subsubsection{Quantitative Results from Traditional Internal Events}

Table 1 summarizes the results of the event tree quantification, showing the core damage frequency as a function of the initiating events and POSs. The core damage frequency is the frequency that core damage occurs while the reactor is at mid-loop, and includes the fraction of a year that the reactor is at mid-loop. POS 6 of a drained maintenance outage (D6), and POS 6 of a refueling outage are the most dominant POSs. The characteristics of these POSs are high decay heat level and a relatively short time available for operator action. In contrast, POS 10 of a refueling outage has a very low decay heat, and its core damage frequency is approximately one order of magnitude lower.

Table 2 compares the results of this study with those of NUREG-1150 and the individual plant examination (IPE) performed by the utility for Surry. The results are displayed in two ways. The core damage frequency, shown in the first row, is the frequency that core damage occurs when the plant is at mid-loop (the core damage frequencies in the parentheses are the contributions due to over-draining events), and the core damage frequency, shown in the third row, is the core damage frequency (minus the contribution of over-draining events) divided by the fraction of time the plant is at mid-loop (second row). The former accounts for the fact that the plant is at mid-loop only a small fraction of the time, while the latter is the core damage frequency conditional on the plant being at mid-loop. The core damage frequency of mid-loop operation is approximately an order of magnitude lower than the CDF estimated in NUREG-1150 for power operation. However, the plant is only at mid-loop operation approximately $7 \%$ of a calendar year. The numbers in the parentheses of the third row of the table are the conditional probability of core damage due to over-draining events, given that the plant enters mid-loop operation in the POS.

The core damage frequencies shown in the first row of Table 2 are additive. That is, the sum of the core damage frequencies of the three POSs is the total core damage frequency of mid-loop operation. This total (5 E-06 per year) can be added to the core damage frequency of power operation (e.g., 4 E-05 per year for NUREG-1150). Therefore, the sum of $4.5 \mathrm{E}-05$ per year is the frequency per year that core damage occurs while the plant is at full power or midloop operation.

The core damage frequency shown in the third row of Table 2 is conditional on the plant being at mid-loop. The fact that the conditional core damage frequency of mid-loop operation (7.6E-05 per year) is higher than that of full power operation (4E-05 per year) indicates that mid-loop operation may be more vulnerable to core damage than full power operation. However, the plant is at mid-loop only a small fraction of the time.

Table 3 lists the conditional core damage frequency as a function of the time windows and POSs. The conditional core damage frequency is the rate at which core damage occurs given that the plant is in the time window of the POS. It is obtained by dividing the core damage frequency by the fraction of time the plant is in the time window of the POS. The conditional core damage frequency is a measure that can be used to compare the vulnerability of the time windows and POSs with respect to core damage. It can be seen, from Table 3, that for each POS the conditional 
4 Results

Table 1 Summary of Results: Core Damage Frequency by Initiating Event and Plant Operational States

\begin{tabular}{|c|c|c|c|c|c|}
\hline & \multirow[t]{2}{*}{ Initiating Event } & \multicolumn{4}{|c|}{$\begin{array}{c}\text { Point Estimate Core Damage } \\
\text { Frequency } \\
\text { (per year) }\end{array}$} \\
\hline & & R6 & $\mathbf{R} 10$ & D6 & Total \\
\hline \multirow[t]{6}{*}{1.} & Loss of RHR & & & & \\
\hline & RHR2A-Over Draining & $1.8 \mathrm{E}-7$ & $5.3 \mathrm{E}-8$ & $2.6 \mathrm{E}-7$ & 4.9E-7 \\
\hline & RHR2B-Failure to Maintain Level & 2.1E-08 & $2.0 \mathrm{E}-8$ & $2.9 \mathrm{E}-8$ & $7.0 \mathrm{E}-8$ \\
\hline & RHR3-Non-Recoverable Loss of RHR & $1.5 \mathrm{E}-7$ & 8.4E-9 & $3.0 \mathrm{E}-7$ & $4.6 \mathrm{E}-7$ \\
\hline & $\begin{array}{l}\text { RHR4-Non-Recoverable Loss of Operating Train of } \\
\text { RHR }\end{array}$ & $7.6 \mathrm{E}-9$ & $1.2 \mathrm{E}-9$ & $2.3 \mathrm{E}-8$ & $3.2 \mathrm{E}-8$ \\
\hline & RHR5-Recoverable Loss of RHR & $4.0 \mathrm{E}-8$ & 4.1E-09 & $9.3 \mathrm{E}-8$ & $1.4 \mathrm{E}-7$ \\
\hline \multirow[t]{6}{*}{2.} & LOOP-Loss of Offsite Power & & & & \\
\hline & L1-Both $1 \mathrm{H}$ and $1 \mathrm{~J}$ Energized & 3.3E-7 & $7.0 \mathrm{E}-8$ & $7.6 \mathrm{E}-7$ & $1.2 \mathrm{E}-6$ \\
\hline & $\mathrm{L} 2-1 \mathrm{H}$ and $2 \mathrm{H}$ energized, not $1 \mathrm{~J}$ & $1.0 \mathrm{E}-7$ & $1.3 \mathrm{E}-8$ & $1.7 \mathrm{E}-7$ & $2.9 \mathrm{E}-7$ \\
\hline & L3-1H energized, not $1 \mathrm{~J}$, unit 2 blackout & $4.2 \mathrm{E}-8$ & $1.3 \mathrm{E}-8$ & $9.9 \mathrm{E}-8$ & $1.5 \mathrm{E}-7$ \\
\hline & B1-Unit 1 Blackout & $4.8 \mathrm{E}-8$ & $1.1 \mathrm{E}-8$ & $1.7 \mathrm{E}-7$ & $2.3 \mathrm{E}-7$ \\
\hline & B2-2 Unit Blackout & $3.8 \mathrm{E}-8$ & 4.2E-8 & $1.1 \mathrm{E}-7$ & $1.9 \mathrm{E}-7$ \\
\hline 3. & $4 \mathrm{KV}$-Loss of $4 \mathrm{kV}$ Bus & $1.4 \mathrm{E}-7$ & $1.9 \mathrm{E}-8$ & $2.4 \mathrm{E}-7$ & 4.0E-7 \\
\hline 4. & VITAL-Loss of Vital Bus & $2.8 \mathrm{E}-8$ & 5.1E-9 & $7.3 \mathrm{E}-8$ & $1.1 \mathrm{E}-7$ \\
\hline 5. & AIR-Loss of Outside Instrument Air & 7.9E-10 & - & $3.2 \mathrm{E}-9$ & 4.0E-9 \\
\hline 6. & CCW-Loss of CCW & $6.3 \mathrm{E}-8$ & $1.1 \mathrm{E}-10$ & 2.1E-7 & 2.7E-7 \\
\hline 7. & SWGR-Loss of Emergency Switchgear Room Cooling & $3.6 \mathrm{E}-8$ & $1.2 \mathrm{E}-8$ & $7.4 \mathrm{E}-8$ & $1.2 \mathrm{E}-7$ \\
\hline 8. & ESFAS-Inadvertent Safety Feature Actuation & 2.7E-7 & $2.7 \mathrm{E}-8$ & $6.8 \mathrm{E}-7$ & $9.8 \mathrm{E}-7$ \\
\hline 9. & Dilute-Boron Dilution (CDF) & & & & $6.8 \mathrm{E}-08$ \\
\hline TOTAL & & $1.5 \mathrm{E}-6$ & $3.0 \mathrm{E}-7$ & $3.3 \mathrm{E}-6$ & $5.1 E-6^{*}$ \\
\hline
\end{tabular}

Notes: * Not including boron dilution

R6 = Plant operational State 6 of a refueling outage

R10 = Plant operational State 10 of a refueling outage

D6 = Plant operational State 6 of a drained maintenance 
Table 2 Comparison of Total Core Damage Frequency (CDF) with NUREG-1150 and IPE

\begin{tabular}{|c|c|c|c|c|c|}
\hline \multirow{5}{*}{$\begin{array}{l}\text { Study } \\
\text { PWR Low Power and Shutdown Study } \\
\text { (Mid-Loop POSs, Internal Event Only, } \\
\text { Point Estimate) }\end{array}$} & \multicolumn{5}{|c|}{ Results } \\
\hline & & R6 & $\mathbf{R 1 0}$ & D6 & TOTAL \\
\hline & $\mathrm{CDF}^{\star}$ per year & $\begin{array}{l}1.6 \mathrm{E}-06 \\
(1.8 \mathrm{E}-07)^{* *}\end{array}$ & $\begin{array}{l}3.1 \mathrm{E}-07 \\
(5.5 \mathrm{E}-08)^{* *}\end{array}$ & $\begin{array}{l}3.3 \mathrm{E}-06 \\
(2.7 \mathrm{E}-07)^{* *} \\
\end{array}$ & $\begin{array}{l}5.1 \mathrm{E}-06 \\
(5.0 \mathrm{E}-07)^{* *}\end{array}$ \\
\hline & $\begin{array}{l}\text { Fraction of a year the plant } \\
\text { is in mid-loop }\end{array}$ & $1.6 \mathrm{E}-02$ & $1.5 \mathrm{E}-02$ & $3.5 \mathrm{E}-02$ & $6.6 \mathrm{E}-02$ \\
\hline & $\begin{array}{l}\text { Conditional } \mathrm{CDF}^{\star \star \star \star} \text { per year } \\
\text { (CDP) }\end{array}$ & $\begin{array}{l}8.3 \mathrm{E}-05 \\
(3.0 \mathrm{E}-07) \\
\end{array}$ & $\begin{array}{c}1.7 \mathrm{E}-05 \\
(1.8 \mathrm{E}-07) \\
\end{array}$ & $\begin{array}{l}8.7 \mathrm{E}-05 \\
(2.3 \mathrm{E}-07) \\
\end{array}$ & $\begin{array}{l}7.6 \mathrm{E}-05 * * * * \\
(2.4 \mathrm{E}-07) \\
\end{array}$ \\
\hline $\begin{array}{l}\text { NUREG-1150 (Internal Events Only, } \\
\text { at Power, Mean Value) }\end{array}$ & \multicolumn{5}{|c|}{$4.0 \mathrm{E}-05$} \\
\hline IPE (Internal Event Only, Point Estimate) & \multicolumn{5}{|c|}{ 7.4E-05 } \\
\hline
\end{tabular}

\footnotetext{
* CDF reflects the fraction of time the plant is at mid-loop

** Contribution of over-draining events

*** Frequency of core damage given that the plant is at mid-loop

**** Average over the POSs

(CDP) probability of core damage due to over-draining upon entering the POS
} 
4 Results

Table 3 Conditional Core Damage Frequency As a Function of the Time Windows and POSs (per year)

\begin{tabular}{|c|c|c|c|c|}
\hline & R6 & R10 & D6 & Average \\
\hline \hline $\begin{array}{c}\text { Window 1 } \\
(13 \mathrm{hr}-75 \mathrm{hr})\end{array}$ & $1.0 \mathrm{E}-03$ & - & $3.4 \mathrm{E}-04$ & $3.8 \mathrm{E}-04$ \\
\hline $\begin{array}{c}\text { Window 2 } \\
(75 \mathrm{hr}-240 \mathrm{hr})\end{array}$ & $7.6 \mathrm{E}-05$ & - & $5.9 \mathrm{E}-05$ & $7.3 \mathrm{E}-05$ \\
\hline $\begin{array}{c}\text { Window 3 } \\
(240-768 \mathrm{hr})\end{array}$ & $5.5 \mathrm{E}-05$ & $6.5 \mathrm{E}-05$ & $5.2 \mathrm{E}-05$ & $5.6 \mathrm{E}-05$ \\
\hline $\begin{array}{c}\text { Window } 4 \\
(>768 \mathrm{hr})\end{array}$ & $1.9 \mathrm{E}-05$ & $1.6 \mathrm{E}-05$ & $1.1 \mathrm{E}-05$ & $1.8 \mathrm{E}-05$ \\
\hline Average & $8.3 \mathrm{E}-05$ & $1.7 \mathrm{E}-05$ & $8.7 \mathrm{E}-05$ & $7.0 \mathrm{E}-05$ \\
\hline
\end{tabular}

Notes:

R6 = Plant Operational State 6 of a refueling outage

R10 $=$ Plant Operational State 10 of a refueling outage

D6 = Plant Operational State 6 of a drained maintenance

core damage frequency decreases with time window. This is due to the relaxed success criteria and more time available for operator actions in the later time windows. The conditional core damage frequency for R6 or R10 is higher than for D6 mainly because the RCS loops have a high probability of being isolated in a refueling outage which makes reflux cooling impossible. For example, in window 1, the probability that the loops are isolated in a refueling outage is 0.3 , and the probability that reflux cooling fails in a drained maintenance outage is 0.1 (modeled as a recovery action). The difference between R6 and R10 in windows 3 and 4 is due to the difference in maintenance unavailabilities.

The averages in Table 3 represent the averaged (weighted by the frequency that initiating events occur) conditional core damage frequency. For example, the averaged conditional core damage frequency for R6 is $8 \mathrm{E}-05$ per year, while that for $\mathrm{D} 6$ is $9 \mathrm{E}-05$ per year. This does not contradict the comparison made earlier for a given time window of the POSs, because given that plant is in D6 the plant is more likely to be in the earlier time windows that have higher conditional core damage frequency. The averaged conditional core damage frequency over the POSs, shown in the last column of Table 3 , does show the trend of decreasing with decay heat.

Table 4 lists the key uncertainty characteristics of the core damage frequencies for mid-loop operation and power operation, and shows that the core damage for mid-loop operation has a larger dispersion than that of power operation. Note also that the mean CDF in Table 4 is slightly different for the total CDF in Tables 1 and 2. This is because the numbers in Tables 1 and 2 are point estimates whereas the information in Table 4 reflects an uncertainty analysis. 
Table 4 Result of the Level 1 Uncertainty Analysis and Comparison with Full Power Operation (per year)

N

\begin{tabular}{|c|c|c|c|c|c|c|c|}
\hline & Study & & Mean & $\begin{array}{c}\text { 5th } \\
\text { Percentile } \\
\end{array}$ & $\begin{array}{c}\text { 50th } \\
\text { Percentile } \\
\end{array}$ & $\begin{array}{c}\text { 95th } \\
\text { Percentile } \\
\end{array}$ & $\begin{array}{l}\text { Error } \\
\text { Factor } \\
\end{array}$ \\
\hline \multirow{3}{*}{$\begin{array}{l}\text { Internal } \\
\text { Events }\end{array}$} & \multicolumn{2}{|c|}{ Full Power Operation - NUREG 1150 (per year) } & 4.0E-05 & $6.8 \mathrm{E}-06$ & 2.3E-05 & $1.3 \mathrm{E}-04$ & 4.4 \\
\hline & \multicolumn{2}{|l|}{ Full Power Operation- IPE } & 7.4E- $05^{*}$ & - & - & 一 & 一. \\
\hline & \multicolumn{2}{|l|}{ Mid-Loop Operation (per year) } & 4.9E-06 & 4.8E-07 & 2.1E-06 & $1.5 \mathrm{E}-05$ & 5.7 \\
\hline \multirow{3}{*}{$\begin{array}{l}\text { Internal } \\
\text { Fires }\end{array}$} & \multicolumn{2}{|c|}{ Full Power Operation - NUREG 1150 (per year) } & $1.1 \mathrm{E}-05$ & - & - & - & - \\
\hline & \multicolumn{2}{|l|}{ Full Power Operation- IPE } & $* *$ & - & - & - & - \\
\hline & \multicolumn{2}{|l|}{ Mid-Loop Operation (per year) } & $2.2 \mathrm{E}-05$ & $1.4 \mathrm{E}-06$ & $9.1 \mathrm{E}-06$ & $7.6 \mathrm{E}-05$ & 7.2 \\
\hline \multirow{3}{*}{$\begin{array}{l}\text { Internal } \\
\text { Flood }\end{array}$} & \multicolumn{2}{|c|}{ Full Power Operation - NUREG 1150 (per year) } & $* * *$ & - & - & - & - \\
\hline & \multicolumn{2}{|l|}{ Full Power Operation- IPE } & $5.0 \mathrm{E} 05^{* *}$ & - & - & - & - \\
\hline & \multicolumn{2}{|l|}{ Mid-Loop Operation (per year) } & 4.8E-06 & 2.2E-07 & $1.7 \mathrm{E}-06$ & $1.8 \mathrm{E}-05$ & 9.0 \\
\hline \multirow{5}{*}{$\begin{array}{l}\text { Seismic } \\
\text { Events }\end{array}$} & \multirow{2}{*}{$\begin{array}{l}\text { Full Power Operation - NUREG } 1150 \\
\text { (per year) }\end{array}$} & LLNL & $1.2 \mathrm{E}-04$ & - & - & - & 33 \\
\hline & & EPRI & 4.0E-05 & - & 二 & - & 4.4 \\
\hline & \multicolumn{2}{|l|}{ Full Power Operation- IPE } & ** & 二 & - & 一 & - \\
\hline & \multirow[t]{2}{*}{ Mid-Loop Operation (per year)**** } & LLNL & 3.5E-07 & $1.3 \mathrm{E}-09$ & $4.0 \mathrm{E}-08$ & $1.4 \mathrm{E}-06$ & 32 \\
\hline & & EPRI & $8.6 \mathrm{E}-08$ & $2.5 \mathrm{E}-10$ & 9.7E-09 & 3.7E-07 & 37 \\
\hline
\end{tabular}

* point estimate

** not available

*** below truncation of $1.0 \mathrm{E}-08$ per year

**** refueling outage only (no drained maintenance) 


\subsubsection{Insights from Internal Event Analysis}

The following insights were gained from this study. They are based on the Surry-specific design and operation. Their applicability and significance with respect to other PWRs would have to be assessed separately.

\section{Operator Response}

The dominant cause of core damage was the operator's failure to mitigate the accident. (There is very large uncertainty in the human error probabilities used in this study.) In general, it would be beneficial to have good training, procedures, and instrumentation to ensure that the utility's staff can respond to shutdown accidents.

\section{Procedures for Shutdown Accidents}

Very few procedures are available for accidents during shutdown; the procedure for loss of decay heat removal, AP 27.00 , is the only one that was written specifically for the shutdown scenarios analyzed in this study. The procedure is conservative with regard to the equipment needed to establish reflux cooling and feed-and-bleed. In this study, the use of fewer than the number of steam generators specified in the procedure for reflux cooling was treated as a recovery action, and a more realistic success criteria was used for feed-and-bleed when the decay heat is high. In most cases, the information in the procedures for power operation is helpful, for shutdown accidents. For example, the procedure for station blackout, ECA-0.0, gives instructions for dumping steam to the condenser. Credit for this procedure was taken into account in this study. However, some procedures written for power operation would mislead the operator if followed during shutdown. For example, the procedure for loss of offsite power, AP 10.00, states that "When the EDG is the only source of power to an emergency bus, the Component Cooling Pump should NOT be in service". During shutdown, CCW flow to the RHR heat exchanger is necessary for decay heat removal. Therefore, following this procedure under these circumstances would not be the most appropriate operator response.

\section{Instrumentation}

The level instrumentation used during mid-loop operation (i.e., standpipe level instrumentation and ultra-sonic level instrumentation) has limited applicability during a shutdown accident. The standpipe system indicates the correct level only when there is no build-up of pressure in the system. The ultra-sonic level instrumentation only provides level indication when the level is within the reactor coolant loops, and therefore, may not be useful during a feed and bleed operation.

\section{Supporting Thermal-Hydraulic Analysis}

The thermal-hydraulic behavior of the reactor coolant system is rather complex, mainly because the pressurizer is usually the relief path for coolant or steam, and the vessel head does not have a large vent. When performing thermal-hydraulic analysis in support of the PRA effort, consideration must be given to longer term system behavior, at least $\mathbf{2 4}$ hours into the accident. In this study, such calculations were done for feed-and-bleed operation using a charging pump, and with gravity feed from the RWST. Additional calculations would be helpful to better understanding the effectiveness of reflux cooling, and feed and bleed using a low pressure injection pump. In this study, the conservative results of the Virginia Power Technical Report \# 865 (Revision 1, dated July 3, 1992) ${ }^{[10]}$ were used to determine the number of steam generators needed as a function of time after shutdown, because such criteria 
are explicitly written in the procedure for loss of RHR. In the event trees and fault trees, it was conservatively assumed that if there were too few steam generators, then no credit was given to reflux cooling. In this case, reflux cooling still would help. In fact, a review of the studies performed by Westinghouse ${ }^{[9]}$ and the Idaho National Engineering Laboratory ${ }^{[7,8]}$ found that one steam generator is sufficient for any level of decay heat. To take some credit for reflux cooling in this case, a recovery action with failure probability 0.1 was applied to those core damage cutsets that involve failure of reflux cooling due to insufficient steam generators. It was assumed that hot-leg injection using a low head injection pump is adequate to prevent core damage. Due to the low shut-off head of the pumps, approximately $150 \mathrm{psig}$, the concern is that if boiling takes place in the system, the low head pump may be unable to inject.

\section{Maintenance Unavailability}

A review of shift supervisor's log books and minimum equipment lists for three refueling outages showed that the maintenance unavailabilities of equipment that can be used to mitigate an accident were very high. For example, two out of three charging pumps were found to be tagged out practically throughout the whole mid-loop period. The two low-head injection pumps also were unavailable a large fraction of the time. Generic Letter 88-17, requires the plant to have one high-head pump and one low-head pump available. For the purpose of quantification it was assumed that charging pump $A$, charging pump cooling water pump $A$, and low head injection pump $B$ are available. From the check list used for reduced inventory conditions, it was assumed that the maintenance of diesel generators, $4 \mathrm{kV}$ emergency buses, and stub buses is not allowed.

Maintenance unavailability was found to be the dominant cause of equipment unavailability. In combination with human errors, maintenance of the charging pump cooling water pump, the charging pump, and the low head injection pump appear in the dominant cutsets for some of the core damage sequences.

\section{Isolation of Reactor Coolant Loops}

Isolation of the RCS loops is an important contributor to the core damage frequency. Review of the plant shutdown experience indicated that the reactor coolant loops are isolated for extended periods in a refueling outage, making the steam generators unavailable for decay heat removal upon loss of RHR. In a cold shutdown condition, the steam generators are usually maintained in the wet lay-up condition with the secondary side filled with water. During midloop operation, the availability of the SGs makes reflux cooling a possible method of mitigating a loss of RHR; this might be the only mitigation function available in a station blackout.

\section{Single Failures of the RHR System}

The RHR system at Surry has no active safety function (i.e., it does not perform the safety injection function in scenarios initiated at full power). Consequently, many single component failures can cause loss of RHR. In the RHR system, a single suction line from the loop A hot leg and a single flow control valve HCV-1758 are used. During its operation, a single CCW header provides cooling to both RHR pump seal coolers and the operating RHR heat exchanger, and two CCW return lines from the RHR system are used. Hence, a failure of the trip valve 109A or B in one of the two $\mathrm{CCW}$ return lines can cause loss of the system. These trip valves also fail closed on loss of instrument air, or vital bus. Closure of the TV-109 valves is a significant contributor to loss of RHR. It was assumed that the opening of the RHR flow control valve HCV-1758 as a result of loss of vital bus III will cause RHR pump run out: this also was a significant contributor to loss of RHR. 


\section{Results}

\section{Valve Arrangement of Auxiliary Feedwater System and Main Steam System during Shutdown}

The auxiliary feedwater system has six motor operated valves in the flow path to the steam generators, that are normally closed during shutdown. They are difficult to locate during a station blackout. Similarly, the main steam non-return valves are normally closed during shutdown, and have to be opened to use steam dump to the condenser. These valves depend on offsite power and would be very difficult to open without it.

\section{Potential for Plugging the Containment Sump when Recirculation is Needed}

Because of various activities, transient material and equipment are brought into containment during shutdown. For example, large plastic Herculite sheets are often used to separate work areas from the rest of the containment. When an accident requiring recirculation from the containment sump occurs (as in time windows 1 and 2) the material would increase the potential for plugging the containment sump.

\subsubsection{Quantitative Results from Internal Fire Analysis}

Table 5 summarizes the point estimate results from the internal fire analysis. The results of an uncertainty analysis on the core damage frequency due to fires is included in Table 4. The quantification indicates that scenarios in the emergency switchgear room (ESGR), the cable vault and tunnel, and the containment are important contributors to the CDF. The most dominant scenarios occur in the cable vault and tunnel (due to proximity of many emergency cables from both divisions in a closed, constrained space) and in the ESGR, where many emergency cables from both divisions come together in close proximity (before entering the control room). In the containment, the relatively high $\mathrm{CDF}$ is due to a relatively high scenario frequency combined with non-separation of RHR trains over significant distances. Other scenarios are also important, due to moderate damage from the fire combined with a relatively high scenario frequency.

POSs D6 and R6 are much more important than R10 (as R10 occurs in later time windows). D6 is more important than $\mathrm{R} 6$ due to constraints imposed by a drained maintenance outage and its tendency to occur in earlier time windows.

The earlier time windows are more important than the later ones, with window 4 being relatively unimportant. Windows 1 and 2 are of the highest importance, with window 2 being significantly more important than window 1 . While the decay heat is higher and the success criteria are more stringent in window 1, this window is relatively short duration and the outages tend to occur in the later time windows. The most risk significant fire initiator occurs in the cable vault tunnel area, in window 2 and POS D6, followed by a few scenarios in the ESGR, in the same window and POS.

Before the recovery actions were applied, the core damage frequency due to fire events at mid-loop was $2.7 \mathrm{E}-05 / \mathrm{yr}$. After application of recovery actions, the core damage frequency was reduced to $1.7 \mathrm{E}-05 / \mathrm{yr}$. Note that this point estimate differs from the total core damage frequency of Table 5 , i.e., $1.8 \mathrm{E}-05 / \mathrm{yr}$. This is because the total core damage frequency of Table 5 was calculated simply as the sum of the frequencies of the sequences, while the point estimate of 1.7E-05/yr was calculated using the minimum-cutset-upper-bound method implemented in the IRRAS computer code. The recovery actions do not reduce the core damage frequency significantly, because they are only 
effective in windows 3 and 4 (in order to satisfy the 24 hour success criterion), whereas windows 1 and 2 are more dominant.

Table 5 Summary of Point Estimate Core Damage Frequencies for Fire Events (per year)

\begin{tabular}{||l||c|c|c|c||}
\hline \multicolumn{1}{|c|}{ Fire Area } & R6 & D6 & R10 & Total \\
\hline \hline Emergency Switchgear Room & $4.1 \mathrm{E}-06$ & $8.2 \mathrm{E}-06$ & $2.1 \mathrm{E}-07$ & $1.3 \mathrm{E}-05$ \\
\hline Containment & $7.0 \mathrm{E}-08$ & $5.5 \mathrm{E}-07$ & $5.0 \mathrm{E}-09$ & $6.3 \mathrm{E}-07$ \\
\hline Cable Vault and Tunnel & $1.3 \mathrm{E}-06$ & $2.7 \mathrm{E}-06$ & $7.4 \mathrm{E}-08$ & $4.0 \mathrm{E}-06$ \\
\hline Normal Switchgear Room & $1.5 \mathrm{E}-08$ & $3.5 \mathrm{E}-08$ & $1.4 \mathrm{E}-09$ & $5.1 \mathrm{E}-08$ \\
\hline Main Control Room & $7.0 \mathrm{E}-08$ & $5.3 \mathrm{E}-07$ & $4.4 \mathrm{E}-09$ & $6.0 \mathrm{E}-07$ \\
\hline Total & $5.5 \mathrm{E}-06$ & $1.2 \mathrm{E}-05$ & $2.9 \mathrm{E}-07$ & $1.8 \mathrm{E}-05$ \\
\hline
\end{tabular}

Notes:

R6 = Plant Operational State 6 of a refueling outage

$\mathrm{R} 10=$ Plant Operational State 10 of a refueling outage

D6 = Plant Operational State 6 of a drained maintenance

Table 4 summarizes the result of the uncertainty analysis for core damage accidents. The results on internal fires were obtained by performing uncertainty analysis using 500 Latin Hypercube Sampling (LHS) samples. Also shown in the table is the uncertainty analysis results of the internal event analysis as well as the mean value of the internal fire analysis of NUREG-1150.

\subsubsection{Insights from Internal Fire Analysis}

Fires during shutdown are not as prevalent as fires during power operation (after the construction events are taken out). However, a greater potential does exist for fires in certain categories (e.g., transient or welding igniting cables or other equipment fires) during shutdown operations, but the possibility of some types of fires is reduced (e.g., deenergized equipment, oil dripping on hot piping). A fire at shutdown is liable to be detected much sooner and extinguished in its early phases, because of increased floor traffic. (Credit is taken for this by disallowing events that were discovered in the smoking stage (without flames) or early enough such that deenergizing equipment extinguished the fire.) At Surry, a fire watch is in place during welding operations and the fire doors are kept closed.

Human error events are not prominent contributors individually in terms of the Fussell-Vesely importance measure (a few percent). Part of the reason for lack of importance of individual HEPs is that there are many events, each applicable in a small fraction of sequences; another reason is in the values assigned; the third reason is that in many important scenarios hardware failures dominate due to heavy damage by fire. 


\section{Results}

Table 4 provides a comparison of the fire induced core damage frequency during mid-loop operation with that of power operation. Although the plant spends much less time in mid-loop, the core damage frequency is comparable to that of power operation. The main reason for this result is the routing of cables needed to support RHR operation or to mitigate an accident during mid-loop operation. The cable routing is such that a single fire at a few critical locations can damage almost all the equipment need to mitigate the accident, while during power operation much fewer critical locations exist.

\subsubsection{Quantitative Results from Internal Flood Analysis}

The main results of the flood analysis are presented in Table 6, listing the point estimate core damage frequencies of the analyzed operating states. The results of the uncertainty analysis are shown in Table 4, indicating the uncertainty bounds of the core damage frequency due to internal floods. It was found that the most dominant contributors to core damage due to internal floods are accident scenarios initiated in the Turbine Building leading to the draining of the intake canal. This potentially could result in a flood encompassing the plant Emergency Switchgear Rooms (ESGR) leading to a two unit loss of all emergency power (F1 and F2 scenarios). The scenarios account for approximately $85 \%$ of the total core damage frequency (CDF) due to internal floods. This result is mainly due to the specific features of the Surry circulating water system and may not be applicable to other plants. The second most dominating flood scenario involves flooding of the Safeguard/Auxiliary Building in combination with the unavailability of the Refueling Water Storage Tank (RWST). The contribution of these scenarios (F4 and F5) is approximately $13 \%$ of the total internal CDF.

Table 6 Summary of Point Estimate Core Damage Frequencies for Flood Events (per year)

\begin{tabular}{||l|c|c|c|c||}
\hline \multirow{2}{*}{ Scenario } & \multicolumn{3}{c|}{ Core Damage Frequency with Recovery } \\
\cline { 2 - 5 } & $\begin{array}{c}\text { POS 6 } \\
\text { Refueling }\end{array}$ & $\begin{array}{c}\text { POS 6 } \\
\text { Drained }\end{array}$ & $\begin{array}{c}\text { POS 10 } \\
\text { Refueling }\end{array}$ & Total \\
\hline \hline Turbine Building F1 & $1.9 \mathrm{E}-06$ & $9.3 \mathrm{E}-08$ & $1.5 \mathrm{E}-06$ & $3.5 \mathrm{E}-06$ \\
\hline Turbine Building F2 & $4.5 \mathrm{E}-07$ & $2.2 \mathrm{E}-08$ & $3.6 \mathrm{E}-07$ & $8.3 \mathrm{E}-07$ \\
\hline Auxiliary Building F3 & $4.7 \mathrm{E}-08$ & $4.3 \mathrm{E}-08$ & $1.2 \mathrm{E}-08$ & $1.0 \mathrm{E}-07$. \\
\hline Auxiliary Building F4 & $1.6 \mathrm{E}-07$ & $5.7 \mathrm{E}-08$ & $6.7 \mathrm{E}-08$ & $2.8 \mathrm{E}-07$ \\
\hline Safeguard Area F5 & $2.0 \mathrm{E}-07$ & $8.9 \mathrm{E}-08$ & $9.4 \mathrm{E}-08$ & $3.8 \mathrm{E}-07$ \\
\hline Spray in Containment F6 & - & - & - & - \\
\hline Mechanical Equipment Room No. \#3 - F7 & $1.0 \mathrm{E}-08$ & $1.5 \mathrm{E}-08$ & $7.8 \mathrm{E}-09$ & $3.3 \mathrm{E}-08$ \\
\hline \hline Total-Flood & $2.8 \mathrm{E}-06$ & $3.2 \mathrm{E}-07$ & $2.0 \mathrm{E}-06$ & $5.1 \mathrm{E}-06$ \\
\hline
\end{tabular}




\subsubsection{Insights from Internal Flood Analysis}

The internal flood CDF is dominated by Turbine Building flood events. These events are primarily initiated by either valve or expansion joint failures in the main inlet lines of the circulating water system. These failures may lead to pipe ruptures upstream of the condenser water box and inlet valves. At Surry the circulating water system is gravity fed from a very large capacity intake canal and its isolation may not be accomplished in a timely manner. This is in contrast with other common design arrangements where dedicated pumps provide the required cooling water flow through the system. In these designs, stopping the pumps would effectively isolate the system limiting potential water outflow.

The potential draining of the intake canal inventory in the Turbine Building is dominant due to a plant specific spatial interdependence. For both units the Emergency Switchgear Rooms are located in the Service Building on the same elevation as the Turbine Building basement. These areas are separated by a fire door with 2-foot high flood dikes in front of them. A large scale flood could potentially overflow the dikes and enter into the two unit ESGR, leading to the potential loss of emergency power in both units, including the loss of Residual Heat Removal (RHR) stub busses. The normal off-site power supply to the plant would not be affected since the normal SGR is located at higher elevation in the Service Building.

Another important contributor to the internal flood CDF is due to flood events originated or entering into the Auxiliary Building. These flood scenarios, mainly from supply pipe ruptures from the RWST, result in the loss of all Component Cooling Water ( $\mathrm{CCW}$ ) and consequently the RHR function at the plant. This coupled with the unavailability of the RWST inventory to be injected into the reactor core leads to core damage. Again, the plantspecific spatial arrangement of piping and equipment is the main reason for the development of the accident scenario and its risk significance.

\subsubsection{Quantitative Results from Seismic Analysis}

Table 4 shows the base case results. The base case consists of the Surry plant (systems and fragilities) at the Surry site with EPRI and LLNL seismic hazard curves. In this table, the mean, median, 5 percentile and 95 percentile frequencies of the two plant operating states are shown. It is seen from the table that mean annual frequency of the two plant operating states is less than $10^{-6}$ per year using either the LLNL or the EPRI seismic hazard curves. Therefore, it can be concluded that the seismic contribution to the mean annual core damage frequency during both POS 6 and POS 10 is very small at Surry Unit 1.

The comparison of core damage-frequency results is also shown in Table 4. From examining the table, several important observations emerge:

- During shutdown conditions, the total annual mean CDF arising from earthquakes is small compared to the CDF arising from internal initiators: a factor of about 15 smaller for the LLNL seismic hazard curves and a factor of about 60 smaller using the EPRI hazard curves. 
4 Results

- The seismic mean CDF during shutdown is small compared to the mean CDF at full power from seismic initiators from NUREG-1150: a factor of about 350 times smaller for the LLNL hazard curves and about 300 times smaller for the EPRI hazard curves.

- The Error Factor (EF) in this seismic study is significantly greater than the EF in the CDF from internal initiators during shitdown This is primarily due to the large uncertainty in the seismic hazard curves but another contribution arises from the uncertainty in the seismic fragilities.

\subsubsection{Insights from Seismic Analysis}

A number of important insights emerge from this Surry analysis, including:

\section{Core Damage Frequency}

The core damage frequency for earthquake-initiated accidents during refueling outages in POS 6 and POS 10 is found to be low in absolute terms, below $10^{-6} /$ year. The reasons for this are (i) Surry's seismic capacity in responding to earthquakes during shutdown is excellent, well above its design basis and similar to its ability to respond to earthquakes during full-power conditions; (ii) the Surry site isione of the least seismically active locations in the United States; (iii) the Surry plant is only in POS 6 and POS 10 (Gombined) for an average (mean) of $6.6 \%$ of the time.

The core damage frequencies are also low relative to the frequencies during POS 6 and POS 10 for internal initiators. This can be seen in Table 4 .

The Results are Plant Specific

The results for Surry are highly plant-specific, in the sense that the seismic capacities, the specific sequences that are found to be most important, and the seismicity of the site are all difficult to generalize to other reactors elsewhere.

\section{Shutdown Seismic Sequences are Similar to Full-Power Seismic Sequences}

Nevertheless, it is important to observe that all of the sequence types, components, and human errors that enfyrge in the key sequences in this analysis are similar or identical to sequences, components, and human errors that (appear in typical full-power seismic PRAs. That is, nothing that has arisen as important in this study appears to be unique to earthquakes occurring during shutdown conditions. Whether this observation can be generalized to other reactors at other sites is unknown.

\section{Sensitivities}

Sensitivity studies reveal that if the Surry reactor were moved to the Zion site in Illinois (a typical midwestern site) or the Pilgrim site in Massachusetts (one of the most seismically active sites among all of the reactor sites in the eastern U.S.), the mean annual CDF from this study would increase by factors of about 1.8 and 10 , respectively. 


\section{Uncertainties}

While there are significant uncertainties in the numerical values of core damage frequencies found in this study (see Table 4), the above conclusions are relatively robust-they do not depend on the detailed numerical values found.

\subsection{Level 2/3 Results}

\subsubsection{Plant Damage State Frequency}

The CDF analysis is coupled to the accident progression analysis through the plant damage states (PDS). Of particular interest is the characteristics of the PDS groups and their relative contribution to the core damage frequency estimates. The PDS characteristics are important because they strongly influence the subsequent accident progression. Table 7 displays the PDS contributors to the core damage frequency for this study. Four statistical measures (namely the 5th percentile, median, mean and 95th percentile) on the distributions of the various PDS groups are given in Table 7. Similar results from the full power study are also included in the table.

Accident sequences in which the operators did not correctly diagnose the situation or take proper actions were the largest contributor (approximately two-thirds of the total) to the mean core damage frequency for mid-loop operation. Accident sequences that lead to station blackout during mid-loop operation (loss of the $4 \mathrm{kV}$ Bus is similar to a station blackout) contribute about 10 percent to the mean $\mathrm{CDF}$. Other accidents were identified that resulted in loss of core cooling after depletion of the refueling water storage tank and failure of recirculation. The leading cause of recirculation failure was found to be plugging of the suction from the sump. These accidents contribute about 20 percent to the mean core damage frequency.

Station Blackout accidents were the largest contributor (approximately two-thirds of the total) to the mean core damage frequency for accidents initiated by internal events during power operation. Other accidents initiated by lossof-coolant accidents (LOCAs), transient events and anticipated transient without scram (ATWS) contributed about 25 percent to the mean $\mathrm{CDF}$. Accidents that result in containment bypass (steam generator tube ruptures (SGTR) and interfacing systems LOCAs) contributed less than 10 percent to the mean CDF.

The plant damage states in Table 7 cannot be directly compared because the plant configuration during mid-loop operation is different than the configuration during full power operation. For example a Station Blackout during full power operation will have a different accident progression than a Station Blackout during mid-loop operation. An important difference is that the containment may not be isolated during mid-loop operation whereas the containment was found to be isolated for most of the accidents at full power. Differences in the status of containment integrity during mid-loop and full power operation have an important influence on the accident progression analysis and risk estimates. In the following sections differences in the plant configuration (and hence plant damage states) between mid-loop and low power are indicated. 
4 Results

Table 7 Comparison of the PDS Core Damage Frequencies (per reactor year) for Mid-Loop and Full-Power Operation (Internal Events Only)

\begin{tabular}{|c|c|c|c|c|}
\hline \multicolumn{5}{|c|}{ Full-Power Operation } \\
\hline PDS & 5th Percentile & Median & Mean & 95th Percentile \\
\hline \multicolumn{5}{|l|}{ Station Blackout } \\
\hline Short Term & $1.2 \mathrm{E}-7$ & $1.5 \mathrm{E}-6$ & $5.4 \mathrm{E}-6$ & $2.1 \mathrm{E}-5$ \\
\hline Long Term & $1.6 \mathrm{E}-6$ & $1.1 \mathrm{E}-5$ & $2.2 \mathrm{E}-5$ & $6.4 \mathrm{E}-5$ \\
\hline ATWS & $2.9 \mathrm{E}-8$ & $4.2 \mathrm{E}-7$ & $1.4 \mathrm{E}-6$ & $6.5 \mathrm{E}-6$ \\
\hline LOCAs & $1.2 \mathrm{E}-6$ & $3.9 \mathrm{E}-6$ & $6.1 \mathrm{E}-6$ & $2.0 \mathrm{E}-5$ \\
\hline Interfacing LOCA & $3.6 \mathrm{E}-11$ & $4.9 \mathrm{E}-8$ & $1.6 \mathrm{E}-6$ & 8.2E-6 \\
\hline SGTR & $4.5 \mathrm{E}-7$ & $1.4 \mathrm{E}-6$ & $1.8 \mathrm{E}-6$ & $4.7 \mathrm{E}-6$ \\
\hline Total & $9.8 \mathrm{E}-6$ & $2.5 \mathrm{E}-5$ & 4.1E-5 & $1.0 \mathrm{E}-4$ \\
\hline
\end{tabular}

\begin{tabular}{|c|c|c|c|c|}
\hline \multicolumn{5}{|c|}{ Mid-Loop Operation } \\
\hline PDS & 5th Percentile & Median & Mean & 95th Percentile \\
\hline Station Blackout & $1.9 \mathrm{E}-8$ & $1.2 \mathrm{E}-7$ & $4.0 \mathrm{E}-7$ & $1.7 \mathrm{E}-6$ \\
\hline Human Errors & $2.1 \mathrm{E}-7$ & $1,0 \mathrm{E}-6$ & $2.8 \mathrm{E}-6$ & $1.3 E-5$ \\
\hline Loss of Recirculation & $5.3 \mathrm{E}-8$ & $4.1 \mathrm{E}-7$ & $7.8 \mathrm{E}-7$ & $3.3 \mathrm{E}-6$ \\
\hline Loss of $4 \mathrm{kV}$ Bus & $8.9 E-9$ & $8.9 \mathrm{E}-8$ & $2.2 \mathrm{E}-7$ & $1.3 \mathrm{E}-6$ \\
\hline Total & $3.2 \mathrm{E}-7$ & $2.0 \mathrm{E}-6$ & $4.2 \mathrm{E}-6$ & $1.9 \mathrm{E}-5$ \\
\hline
\end{tabular}




\subsubsection{Accident Progression Analysis}

The plant damage states developed for the mid-loop and full power studies cannot be directly compared. An attempt was therefore made to summarize the results of the accident progression analyses performed for the two studies in such a way that differences in containment status could be ascertained for each of the plant damage states. Table 8 summarizes the probability of accident progression bins (APB) conditional on the various PDS groups for full power operation and for mid-loop operation. The table has been constructed in such a way that APBs have the same meaning in both studies. For example accidents that "bypass" containment were identified in the full-power study but not in the mid-loop study, whereas "containment not isolated" was an important APB for accidents during midloop operation but not for full power.

The most significant difference in the results given in Table 8 relates to the probability of the containment not being isolated. In the full power study the probability for the containment not being isolated was very small because during power operation the Surry containment is maintained at a subatmospheric pressure and therefore containment leakage would be detected. However, the probability of the containment not being isolated was determined to be high for most of the plant damage states during mid-loop operation. In fact, the plant damage state that is the largest contributor to the mean core damage frequency (PDS 2 - Human Error) has a very high conditional probability for the containment being open. This is because it was determined in the accident progression analysis that if operator error due to failure to diagnose the accident led to core damage then the operators probably would not have taken measures to isolate containment.

Another difference between the results in Table 8 relates to accidents that bypass the containment. In the full power study accidents that bypass the containment contribute less than 10 percent to the mean CDF but, because they are high consequence events, they are large contributors to the risk estimates. However, in the mid-loop study accidents that bypass the containment (such as SGTRs or interfacing systems LOCAs) were not included because the configuration of the plant precludes such events.

The probability for early containment failure caused by such phenomena as hydrogen combustion, direct containment heating and steam explosions was found to be very low for all PDS groups in the full study. This is because the failure pressure of the containment was determined to be much higher than the design pressure and the loads predicted from the phenomena were generally lower than the failure pressures. The probability for early containment failure was also found to be small for accidents during mid-loop operation except for accidents involving station blackout and loss of the $4 \mathrm{kV}$ bus. For these accident sequences the mean conditional probability for early containment failure was determined to be between 0.1 and 0.2 . The cause of early containment failure was determined to be hydrogen combustion, which is a problem during mid-loop operation for two reasons. Firstly, if the operators are able to isolate containment during an accident in mid-loop operation there is a possibility that they may not be able to achieve full pressure retaining capability in the time available. The higher containment failure probability in the mid-loop study therefore reflects the lower pressure retaining capability of the containment relative to the capability expected during power operation. Secondly, for accidents involving station blackout it is unlikely that an ignition source would be available to ignite the hydrogen until power is recovered. This means that large quantities of unburned hydrogen could accumulate in containment. The higher early containment failure probability for station blackout accidents during mid-loop operation therefore also reflects the possibility that power will be restored after a large quantity of hydrogen has accumulated in containment. 
Table 8 Comparison of the Mean Probabilities of APBs Conditional on PDS Groups for Mid-Loop and Full-Power Operation (Internal Events Only)

\begin{tabular}{|c|c|c|c|c|c|c|c|c|c|c|c|}
\hline \multirow{3}{*}{$\begin{array}{c}\text { Accident } \\
\text { Progression } \\
\text { Bin } \\
\text { Groups }\end{array}$} & \multicolumn{11}{|c|}{ Plant Damage State Groups $\dagger$} \\
\hline & \multicolumn{6}{|c|}{ Full-Power Operation* } & \multicolumn{5}{|c|}{ Mid-Loop Operation** } \\
\hline & $\begin{array}{c}\text { SBO } \\
(2.8 \mathrm{E}-5)\end{array}$ & $\begin{array}{l}\text { ATWS } \\
(1.4 \mathrm{E}-6)\end{array}$ & $\begin{array}{c}\text { Transients } \\
(1.8 \mathrm{E}-6)\end{array}$ & $\begin{array}{l}\text { LOCAs } \\
(6.1 \mathrm{E}-6)\end{array}$ & $\begin{array}{l}\text { Bypass } \\
\text { (3.4E-6) }\end{array}$ & $\begin{array}{l}\text { All } \\
(4.1 \mathrm{E}-5)\end{array}$ & $\begin{array}{l}\text { SBO } \\
(4 E-7)\end{array}$ & $\begin{array}{c}\text { Human } \\
\text { Error } \\
(2.8 \mathrm{E}-6)\end{array}$ & $\begin{array}{c}\text { Loss of } \\
\text { Recirculation } \\
(7.8 \mathrm{E}-7)\end{array}$ & $\begin{array}{c}\text { Loss of } \\
4 \mathrm{kV} \text { Bus } \\
(2.2 \mathrm{E}-7)\end{array}$ & $\begin{array}{l}\text { All } \\
(4.2 \mathrm{E}-6) \\
\end{array}$ \\
\hline $\begin{array}{l}\text { Early } \\
\text { Containment } \\
\text { Failure }\end{array}$ & .01 & Neg. & Neg. & .01 & - & .01 & .17 & - & .03 & 11 & .03 \\
\hline $\begin{array}{l}\text { Late } \\
\text { Containment } \\
\text { Failure }\end{array}$ & .08 & .05 & .01 & .05 & - & .06 & - & 一 & - & - & - \\
\hline $\begin{array}{l}\text { Containment } \\
\text { Bypass }\end{array}$ & Neg. & .08 & .01 & - & 1.0 & .12 & - & - & 一 & - & - \\
\hline $\begin{array}{l}\text { Containment } \\
\text { Not Isolated }\end{array}$ & - & - & 一 & 一 & - & - & .28 & .95 & .10 & .28 & .69 \\
\hline $\begin{array}{l}\text { No VB, } \\
\text { No CF }\end{array}$ & .31 & .52 & .22 & .59 & - & .34 & .37 & .02 & 一 & .39 & .07 \\
\hline VB, No CF & .6 & .35 & .76 & .35 & - & .47 & .18 & .03 & .87 & .22 & .21 \\
\hline
\end{tabular}

* Reproduced from NUREG/CR-4551, Volume 3

** Reproduced from NUREG/CR-6144, Volume 6

*** The values given under the "All" column are frequency-weighted averages and not totals.

$\dagger$ Values given in parentheses are core damage frequency per reactor year for each plant damage state group.

VB Vessel Breach

$\checkmark \quad \mathrm{CF}$ Containment Failure

Neg. Negligible $(<0.01)$ 
The conditional probability of late containment failure, caused by the core debris penetrating the basemat or by overpressurizing the containment (due to the accumulation of steam and noncondensible gases) was determined to be between 0.01 and 0.1 for accidents during full power operation. Both of these failure mechanisms were eliminated for accidents during mid-loop operation based on deterministic calculations. The calculations indicated that the decay heat levels for accidents during mid-loop operation were not sufficiently high to cause late containment failure by basemat penetration or containment overpressurization.

Finally, the mean conditional probability of the containment being intact (i.e., isolated, not bypassed, no excessive leakage, and no containment failure) was determined to be high (i.e., between 0.8 and 0.9 ) for all PDS groups in the full power except for the PDS group containing bypass accidents. As noted above, bypass accidents contribute less than 10 percent to the mean CDF in the full power study. The mean conditional probability of the containment being isolated varied over a wide range for accidents during mid-loop operation. The range varied from 0.05 (Human Error PDS) to about 0.9 for accidents involving loss of recirculation. However, as the Human Error PDS is the largest contributor to the mean CDF the probability of the containment being intact conditional on the mean CDF for all internal events during mid-loop operation was less than 0.3 . This compares with a probability of the containment being intact conditional on the mean CDF for accidents during power operation of over 0.8 . This difference in containment integrity during mid-loop and full power operation has an important influence on the risk estimates.

\subsubsection{Results of the Source Term Analysis}

The source term model (SURSOR) used in the full power study was considered suitable for use in the mid-loop study with only minor modifications. This suitability was based on comparisons with calculations from a deterministic code, MELCOR, and the views expressed by an expert review panel drawn from staff at Sandia and Brookhaven National Laboratories. Therefore, as the same source term model was used in the two studies the source terms are similar for similar accident progression bins. Although the source term calculations are similar for the two studies the risk estimates for mid-loop operation are influenced by the changing radionuclide inventories for the various accidents because they can occur a long time after shutdown. In order to account for the changing radionuclide inventory the partitioning method used in the full power study to combine the source terms into a smaller number of representative source term groups had to be modified for the mid-loop study. Therefore, a direct comparison of the source term groups determined for the two studies would be difficult because of the changing inventory associated with accidents during mid-loop operation.

\subsubsection{Consequence Analysis}

The approach used to calculate offsite consequences was similar in both studies. The major difference was that the latest version of the MACCS code was used to evaluate the offsite consequence measures in the mid-loop study. The latest version of MACCS incorporates the BEIR V update to the latent cancer versus dose relationship, whereas the full power study used in an earlier version of MACCS, which did not include the latest BEIR V update. The latest BEIR V update gives a factor of approximately three times higher latent cancers for the same value of population dose.

Vol. 1 


\subsubsection{Risk Analysis}

Table 9 presents statistical measures of the distributions for seven consequence measures for accidents during midloop operation obtained from this study. Similar statistical measures for full power operation obtained from the NUREG-1150 study of Surry are also included in the table.

Table 9 indicates that the mean risk of offsite early health effects is over two orders of magnitude lower for accidents during mid-loop operation than for full power in spite of the lack of mitigative features. This is due to the natural decay of the radionuclide inventory (because the accidents occur a long time after shutdown) particularly the shortlived isotopes of iodine and tellurium, which are primarily associated with early health effects. The statistical measures for latent cancer fatalities (only 1000 miles was reported in Ref. 1) differ by a factor of approximately three, although the statistical measures for population dose (1000 miles) for mid-loop and full power operations are similar. This difference is largely explained by differences in the latent cancer versus dose relationship in the different versions of MACCS (as noted above) used in the two studies.

PDS 2 is the largest contributor to risk for all consequence measures. The reason for this is that for accidents where operator errors, such as failure to diagnose or take proper action, play a major role in determining the progression of the accident, it was judged unlikely that actions to isolate containment would be taken. As shown in Table 8, the mean conditional probability of the containment being unisolated was estimated to be almost 0.95 for the accident sequences belonging to PDS group 2.

\subsubsection{Comparison with the Safety Goals}

Comparison of the results of this study against the NRC safety goals is done for the two quantitative health objectives identified in the Commission's policy statement of August 1986. These objectives deal with individual early fatality and latent cancer fatality risks within 1 mile and 10 miles of the site, respectively. The numerical value of these objectives are given in Table 9. The 95th percentile of the distribution for individual latent cancer fatality risk falls more than an order of magnitude below the objective. The 95 th percentile of the distribution for individual early fatality risk falls over two orders of magnitude below the corresponding health objective. The health objectives, however, apply to the total risk of the Surry Plant. The risk estimates of this study are for accidents initiated by internal events during mid-loop operation and therefore reflect only a fraction of the total risk at Surry.

\subsubsection{Insights}

The main finding of the study is that during mid-loop operation the risk of consequence measures related to longterm health effects, latent cancer fatalities and population dose, are high, comparable to those at full power, despite the much lower level of the decay heat and the radionuclide inventory. The reason for this is that containment is likely to be unisolated for a significant fraction of the accidents initiated during mid-loop operation so the releases to the environment are potentially large and the radionuclide species which mostly contribute to long-term health effects (such as cesium) have long half-lives. Accident sequences involving failure to correctly diagnose the situation or take proper actions are the largest contributors to the integrated risk. Another finding of the study is that the risk of early fatalities is low despite the unisolated containment due to the decay of the short-lived radionuclide species 
Table 9 Comparison of Distributions of Risks for Mid-Loop and Full-Power Operation (All Values per Reactor Year; Population Doses in P-Sv per Year)

$\pm$

\begin{tabular}{|c|c|c|c|c|c|c|c|c|c|c|}
\hline & \multicolumn{2}{|c|}{ 5th Percentile } & \multicolumn{2}{|c|}{ Median } & \multicolumn{2}{|c|}{ Mean } & \multicolumn{2}{|c|}{ 95th Percentile } & \multicolumn{2}{|c|}{ Sigma } \\
\hline & $\begin{array}{l}\text { Mid- } \\
\text { Loop }\end{array}$ & $\begin{array}{l}\text { Full- } \\
\text { Power }\end{array}$ & $\begin{array}{l}\text { Mid- } \\
\text { Loop }\end{array}$ & $\begin{array}{l}\text { Full- } \\
\text { Power }\end{array}$ & $\begin{array}{l}\text { Mid- } \\
\text { Loop }\end{array}$ & $\begin{array}{l}\text { Full- } \\
\text { Power }\end{array}$ & $\begin{array}{l}\text { Mid- } \\
\text { Loop }\end{array}$ & $\begin{array}{l}\text { Full- } \\
\text { Power }\end{array}$ & $\begin{array}{l}\text { Mid- } \\
\text { Loop }\end{array}$ & $\begin{array}{l}\text { Full- } \\
\text { Power }\end{array}$ \\
\hline Early Fatalities & $1.3 \mathrm{E}-10$ & $7.6 \mathrm{E}-10$ & $3.6 \mathrm{E}-09$ & $7.0 \mathrm{E}-08$ & $4.9 \mathrm{E}-08$ & 2.0E-06 & $1.6 \mathrm{E}-07$ & $5.4 \mathrm{E}-06$ & $1.7 \mathrm{E}-07$ & N.A. \\
\hline Latent Fatalities within $50 \mathrm{mi}$ & $1.6 \mathrm{E}-04$ & N.A. & 8.3E-04 & N.A. & $2.5 \mathrm{E}-03$ & N.A. & $8.8 \mathrm{E}-03$ & N.A. & 3.7E-03 & N.A. \\
\hline Latent Fatalities within $1000 \mathrm{mi}$ & $8.0 \mathrm{E}-04$ & 3.1E-04 & $5.3 \mathrm{E}-03$ & $2.2 \mathrm{E}-03$ & $1.6 \mathrm{E}-02$ & $5.2 \mathrm{E}-03$ & $5.5 \mathrm{E}-02$ & $1.9 \mathrm{E}-02$ & $2.5 \mathrm{E}-02$ & N.A. \\
\hline Population Dose within $50 \mathrm{mi}$ & $3.8 \mathrm{E}-03$ & $5.9 \mathrm{E}-03$ & $2.0 \mathrm{E}-02$ & 2.7E-02 & $5.8 \mathrm{E}-02$ & $5.8 \mathrm{E}-02$ & $1.9 \mathrm{E}-01$ & 2.5E-01 & $8.8 \mathrm{E}-02$ & N.A. \\
\hline Population Dose within $1000 \mathrm{mi}$ & $1.9 \mathrm{E}-02$ & $1.9 \mathrm{E}-02$ & $1.2 \mathrm{E}-01$ & $1.3 \mathrm{E}-01$ & $3.7 \mathrm{E}-01$ & $3.1 \mathrm{E}-01$ & $1.3 \mathrm{E}+00$ & $1.2 \mathrm{E}+00$ & $5.9 \mathrm{E}-01$ & N.A. \\
\hline Individual Early Fatalities Risk within $1 \mathrm{mi}^{*}$ & $6.0 \mathrm{E}-12$ & $1.4 \mathrm{E}-11$ & $1.3 \mathrm{E}-10$ & 8.7E-10 & $1.7 \mathrm{E}-09$ & $1.6 \mathrm{E}-08$ & $6.9 \mathrm{E}-09$ & $4.9 \mathrm{E}-08$ & $5.5 \mathrm{E}-09$ & N.A. \\
\hline Individual Latent Fatalities Risk within $10 \mathrm{mi*}$ & $1.2 \mathrm{E}-10$ & $1.6 \mathrm{E}-10$ & 7.5E-10 & $4.9 \mathrm{E}-10$ & 2.1E-09 & $1.7 \mathrm{E}-09$ & 7.1E-09 & 8.1E-09 & 3.0E-09 & N.A. \\
\hline
\end{tabular}

N.A. - Not Available

*NRC quantitative health objectives:

- Individual early fatality risk within one mile to be less than $5 \times 10^{-7}$ per reactor year.

- Individual latent cancer fatality risk within 10 miles to be less than $2 \times 10^{-6}$ per reactor year. 


\section{Results}

such as iodine and tellurium which contribute to early fatality risk. The integrated risk estimates have a range of uncertainty extending over approximately two orders of magnitude from the 5 th to the 95 th percentile of the distribution.

\section{Containment Status}

The major factor driving the risk is the status of containment during mid-loop operation. It was determined that there is a high probability that the containment is either unisolated or that it would not have full-pressure retaining. capability during mid-loop operation. This is particularly the case if the operators fail to diagnose the accident as it was judged unlikely that they would take action to isolate containment or could succeed in doing so within the available time frame. This factor played a significant role in influencing the risk estimates of mid-loop operation. During the course of the study, Surry plant personnel made available new procedures for containment closure during mid-loop operation. However, it was difficult to assess the adequacy of these procedures in ensuring the pressure retaining capability of the containment within the time frame encompassed by this study. This feature contributed significantly to the uncertainty in containment status and the estimate of risk.

\section{Availability of Containment Sprays}

There is no requirement at Surry for the containment sprays to be available during shutdown. Plant records show that the spray systems could be inoperable because of maintenance. Spray availability was modeled as an uncertainty parameter in the integrated risk analysis. Since the sprays perform an important safety function in mitigating the effects of releases, spray unavailability contributed both to the risk and its uncertainty.

\section{Possibility of Core Damage Arrest}

The inclusion of the possibility of arresting the core degradation process before vessel failure is an important feature of this analysis as it was for the full power study. Termination of the accident in-vessel can significantly reduce some of the fission product releases and thus the risk. The potential for core recovery depends on the nature of the accident progression and is different for the various PDS groups. Overall, the conditional probability of core damage arrest ranged from 0.23 ( 5 th percentile) to 0.44 (95th percentile) with a mean of 0.35 .

\section{Comparison with Full Power Study}

The mean core damage frequency for accidents during mid-loop operation is about an order of magnitude lower than the mean frequency of accidents caused by internal events at full power. However, the risk distributions obtained for comparable long term health consequences are very similar in the two studies. What this finding implies is that the lower decay heat and lower radionuclide inventory of the mid-loop operating state, compared with full power, is offset by the likelihood of containment being unisolated. Finally, the mean risk of early health effects is over two orders of magnitude lower for accidents during mid-loop operation than for accidents during full power operation. This is due to the natural decay of those radionuclide species which have the greatest impact on early fatality risk because accidents during mid-loop operation occur a long time after shutdown. 


\section{CONCLUSIONS}

This study was successful in developing a methodology to estimate the risk associated with the operation of a PWR during mid-loop operation. The methodology developed and the lessons learned from its application provide the NRC with new tools that could be used in subsequent analyses. The study concentrated the effort on mid-loop operation only. The core damage frequency contributions of other low power and shutdown POSs were analyzed in the coarse screening analysis of the Phase 1 study. The following sections summarize the conclusions of the study.

\subsection{Level 1 Conclusions}

\section{Internal Events}

This study shows that the contribution to the total core damage frequency due to internal events during mid-loop operation at the Surry plant is lower by an order of magnitude than that of power operation. This is mainly due to the much smaller fraction of time that the plant is at mid-loop. The core damage frequency conditional on the plant being at mid-loop is actually higher than that of power operation by nearly a factor of two.

Only a few procedures are available for mitigating accidents that may occur during shutdown. Procedures written specifically for shutdown accidents would be useful. Realistic thermal-hydraulic analysis should be used as the basis of the procedures.

It was assumed that the reduced-inventory checklist was followed, and the maintenance unavailability of equipment not on the list were found to be dominant contributors to system unavailability. However, the checklist is believed to be sufficient for ensuring the availability of essential equipment. The dominant cause of core damage is due to operator errors. It is recognized that there is very large uncertainty in the human error probabilities used in this study.

The time window approach developed in this study provides a more realistic approach to account for changing decay heat levels during shutdown. Without using this approach, the core damage frequency estimates would be an order of magnitude higher.

\section{Internal Fires}

A comparison of the fire induced core damage frequency during mid-loop operation with that of power operation shows that, although the plant spends much less time at mid-loop, the core damage frequencies are comparable. The main reason for this finding is that the routing of the cables needed to support RHR operation or mitigate an accident during mid-loop operation is such that a single fire at a few critical locations can damage almost all the equipment need to mitigate the accident. During power operation, considerably fewer critical locations exist.

Risk significant scenarios were found mainly in the emergency switchgear room (ESGR), the cable vault and tunnel (CVT), and in the containment. In the ESGR, several important scenarios (which are also the most risk significant ESGR scenarios) occur in locations where many cables for the $\mathrm{H}$ and the $\mathrm{J}$ emergency divisions come together in close proximity. The tunnel part of the CVT is a constrained space, where damage would quickly propagate to both divisions (serving many different emergency equipment). In the containment, the risk significance stems from the relatively high fire frequency and non-separation of the two RHR divisions. 


\section{Conclusions}

Three mid-loop POSs, in which reactor coolant system level is lowered to the mid-plane of the hot leg, were analyzed. Two of them occur in a refueling outage (POSs R6 and R10) and one in a drained maintenance outage (POS D6). POSs D6 and R6 are much more important than R10 (as R10 occurs in later time windows). D6 is more important than R6 due to constraints imposed by a drained maintenance outage and its tendency to occur in earlier time windows. The earlier time windows are more important than the later ones, with window 4 being relatively unimportant. Windows 1 and 2 are of the highest importance, with window 2 being significantly more important than window 1. While the decay heat is higher and the success criteria are more stringent in window 1 , this window is of relatively short duration, and mid-loop tends to occur in the later time windows. The most risk significant fire initiator occurs in the cable vault tunnel area, in window 2 and POS D6, followed by a few scenarios in the ESGR, in the same window and POS.

\section{Internal Floods}

In general, the risk contribution from flood events is relatively significant and is dominated by potential flood events in the ESGR coupled with loop isolation. The internal flood CDF is dominated by Turbine Building flood events. These events are primarily initiated by either valve or expansion joint failures in the main inlet lines of the circulating water system. These failures may lead to pipe ruptures upstream of the condenser water box and inlet valves. At Surry the circulating water system is gravity fed from a very large capacity intake canal and its isolation may not be accomplished in a timely manner. This is in contrast with other common design arrangement where dedicated pumps provide the required cooling water flow through the system.

The potential draining of the intake canal inventory in the Turbine Building is dominant because of a plant-specific spatial interdependence. For both units the Emergency Switchgear Rooms are located in the Service Building on the same elevation as the Turbine Building basement. These areas are separated by a fire door with 2-foot high flood dikes in front of them. A large scale flood could potentially overflow the dikes and enter into the two unit ESGR, leading to the potential loss of emergency power in both units, including the loss of stub busses that support the RHR pumps. The normal off-site power supply to the plant would not be affected since the normal switch gear room is located at higher elevation in the Service Building.

The flood initiating event analysis has, in general, indicated that shutdown (and specifically mid-loop operation) does not pose a significant increase in flood risk. A possible exception is flood events coupled with loop isolation, which can occur in later Time Windows 2, 3 and 4.

\section{Seismic Events}

The core damage frequency for earthquake-initiated accidents during refueling outages in POS R6 and POS R10 was found to be low in absolute terms, below $10^{-6}$ /year. The reasons for this are (I) Surry's seismic capacity in responding to earthquakes during shutdown is excellent, well above its design basis and similar to its ability to respond to earthquakes during full-power conditions; (ii) the Surry site enjoys one of the least seismically active locations in the United States; (iii) the Surry plant is only in POS R6 and POS R10 (combined) on average for a relatively short period.

The seismic mean CDF during shutdown is small compared to the mean CDF at full power from seismic initiators: ${ }^{[2]}$ a factor of about 350 times smaller for the LLNL hazard curves and about 300 times smaller for the EPRI hazard curves. 


\subsection{Level 2/3 Conclusions}

A systematic evaluation of risk has been performed for mid-loop operation at the Surry Unit 1 plant. The analysis includes accident frequency, accident progression, source terms, consequences, risk, and a determination of the uncertainty in each of the component analyses and in the final risk measures. The analysis takes into account the long time after shutdown that the accidents can occur and the impact of the consequent decay in power level and radionuclide inventory on the risk. The inclusion of this time factor in a risk analysis is a new development in PRA technology and represents a strength of the study from the methodological standpoint.

The results contained in this report are based on the analysis of accident frequency during mid-loop operation where the accident sequences leading to core damage were binned into four plant damage states (PDS) groups: PDS1 (station blackout events), PDS 2 (human errors, failure to diagnose or take proper actions on the part of the operators), PDS 3 (recirculation cooling failure), and PDS 4 (loss of $4 \mathrm{kV}$ bus). These PDSs served as the entry point for the further analysis of accident progression, the determination of potential recovery actions, and the evaluation of source terms, consequences, and risk.

The main finding of the study is that during mid-loop operation the risk of consequence measures related to long-term health effects, latent cancer fatalities, and population dose, are high, comparable to those at full power, despite the much lower level of the decay heat and the radionuclide inventory. The reason for this is that there is a lack of mitigative features for a significant fraction of the accidents initiated during mid-loop operation so the releases to the environment are large and the radionuclide species which mostly contribute to long-term health effects (such as cesium) have long half-lives. PDS 2 (diagnostic and corrective action failures) makes the largest contribution to the risk. Another finding of the study is that the risk of early fatalities is low despite the unisolated containment due to the decay of the short-lived radionuclide species, such as iodine and tellurium which contribute to early fatality risk. The risk estimates have a range of uncertainty extending over approximately two orders of magnitude from the 5th to the 95th percentiles of the distribution. 



\section{References}

1. U.S. Nuclear Regulatory Commission, "Reactor Safety Study, An Assessment of Accident Risks in U.S. Commercial Nuclear Power Plants," WASH-1400, NUREG-75/014, 1975.

2. U.S. Nuclear Regulatory Commission, "Severe Accident Risks: An Assessment for Five U.S. Nuclear Power Plants," NUREG-1150, December 1990.

3. Chu, T.-L., et. al., "PWR Low Power and Shutdown Accident Frequencies Program, Phase 1-Coarse Screening Analysis," Draft Letter Report, November 1991. Available in the NRC Public Document Room, $2120 \mathrm{~L}$ Street, NW, Washington, DC.

4. Institut de et de Surte Nucleaire, "A Probabilistic Safety Assessment of the Standard French $900 \mathrm{MWe}$ Pressurized Water Reactor,” Main Report, April, 1990.

5. Whitehead, D. W., et al., "Evaluation of Potential Severe Accidents During Low Power and Shutdown Operations at Grand Gulf, Unit 1," NUREG/CR-6143, SAND93-2440, Sandia National Laboratory, June 1994.

6. Summers, R.M., et.al., "MELCOR 1.8.0: A Computer Code for Nuclear Reactor Severe Accident Source Term and Risk Assessment Analysis," NUREG/CR-5531, Sandia National Laboratories, January 1991.

7. Naff, S.A., et.al., "Thermal-Hydraulic Processes During Reduced Inventory Operation with Loss of Residual Heat Removal," NUREG/CR-5855, Idaho National Engineering Laboratory, April 1992.

8. Wald, L.W., et.al., "Consequence of the Loss of Residual Heat Removal Systems in Pressurized Water Reactors," NUREG/CR-5820, Idaho National Engineering Laboratory, May 1992.

9. Audreycheck, T.S., et. al., "Loss of RHRs Cooling while the RCS is partially filled," WCAP - 11916, Westinghouse Electric Corporation, July 1988.

10. Virginia Power Company, "Background and Guidance For Ensuring Adequate Decay Heat Removal When RCS Loop Stop Valves are Closed, Surry and North Anna Power Stations," NE Technical Report No.865, Revision 1, June 1992.

11. Chu, T. L. "A Computer Program for Estimating Initiating Event Frequency Using a Two-Stage Bayesian Approach," Letter Report, L-1922, Brookhaven National Laboratory, 1994.

12. Russell, K. D., et al., "Systems Analysis Program for Hands-On Integrated Reliability Evaluations (SAPHIRE) Version 5," Idaho National Engineering Laboratory, NUREG/CR-6116, July 1994.

13. Embrey, D. E., "The Use of Performance Shaping Factors and Quantified Expert Judgment in the Evaluation of Human Reliability: An Initial Appraisal," Brookhaven National Laboratory, prepared for U.S. Nuclear Regulatory Commission, NUREG/CR-2986, May 1983. 
14. Chien, S. H., A. A. Dykes, J. W. Stetkar, and D. C. Bley, "Quantification of Human Error Rates Using a SLIM-Based Approach," Proceedings of the 1988 IEEE Fourth Conference on Human Factors and Power Plants, Monterey, California, June 5-9, 1988.

15. Wheelis, W. T., "User's Guide for a Personal Computer-Based Nuclear Power Plant Fire Data Base," NUREG/CR- 4586, SAND86-0300. Updated to include events through December 1989.

16. Vincent Ho, et al., "COMPBRN III: An Interactive Computer Code for Fire Risk Analysis," EPRI-NP-7282, May 1991.

17. Siu, N. "Modeling Issues in Nuclear Plant Fire Risk Analysis," presented at the EPRI Workshop on Fire Protection, Baltimore, MD, February 9-10, 1989.

18. Nathan Siu and George Apostolakis, "Modeling The Detection And Suppression of Fires in Nuclear Power Plants," from International ANS/ENS Topical Meeting on Probabilistic Safety Methods and Applications, February 24- March 1,1985.

19. Siu, N. and George Apostolakis, "A Methodology for Analyzing the Detection and Suppression of Fires in Nuclear Power Plants", in Nuclear Science And Engineering, 94, pp. 213-226 (1986).

20. Pickard, Lowe and Garrick, Inc. (PLG, Inc.), "Beznau Risk Analysis Plant with NANO", prepared for Nordostschweitzerische Kraftwerke AG, PLG-0511, December 1989.

21. Virginia Power, Surry Nuclear Power Plant, Individual Plant Examination Program, Appendix E: Internal Flooding, August 31, 1991. Available in the NRC Public Document Room, 2120 L Street, NW, Washington, DC.

22. Virginia Electric and Power Company, Internal Flooding Analysis for the Individual Plant Examination, Supplemental Report, Surry Units 1 and 2, November 1991. Available in the NRC Public Document Room, 2120 L Street, NW, Washington, DC.

23. Thomas, H. M. "Pipe and Vessel Failure Probability," Reliability Engineering 2 (1981) 83-124.

24. Bohn, M.P., J.A. Lambright, S.L. Daniel, J.J. Johnson, M.K. Ravindra, P.O. Hashimoto, M.J. Mraz, and W.H. Tong, "Analysis of Core Damage Frequency: Surry Power Station, Unit 1, External Events", NUREG/CR-4551, Vol. 3, Rev. 1, Part 3, Sandia National Laboratories, December 1990.

25. Lambright, J.A., M.P. Bohn, S.L. Daniel, J.J. Johnson, M.K. Ravindra, P.O. Hashimoto, M.J. Mraz, W.H. Tong, and D.A. Brosseau, "Analysis of Core Damage Frequency: Peach Bottom Unit 2, External Events," NUREG/CR-4550, Vol. 4, Rev. 1, Part 3, Sandia National Laboratories, December 1990.

26: Budnitz, R.J., H.E. Lambert, and E.E. Hill, "Relay Chatter and Operator Response After a Large Earthquake," NUREG/CR-4910, Future Resources Associates, Inc., August 1987.

27. Chen, J.T., et al., "Procedural and Submittal Guidance for the Individual Plant Examination of External Events (IPEEE) for Severe Accident Vulnerabilities,"NUREG-1407, U.S. Nuclear Regulatory Commission, June 1991. 
28. Bernreuter, D.L., J.B. Savy, R.W. Mensing and J.C. Chen, "Seismic Hazard Characterization of 69 Nuclear Plant Sites East of the Rocky Mountains," NUREG/CR-5250, Lawrence Livermore National Laboratory, January 1989.

29. Electric Power Research Institute, "Probabilistic Seismic Hazard Evaluations at Nuclear Power Plant Sites in the Central and Eastern United States: Resolution of the Charleston Earthquake Issue," Prepared by Risk Engineering Inc., Yankee Atomic Power Company and Woodward Clyde Consultants, EPRI Report NP-6395-D, April 1989.

30. Griesmeyer, J. M. and L. N. Smith, "A Reference Manual for the Event Progression Analysis Code(EVNTRE)," NUREG/CR-5174, Sandia National Laboratories, September 1989.

31. Jow, H. N., W. B. Murfin and J. D. Johnson, "XSOR Codes User's Manual," NUREG/CR-5360, Sandia National Laboratories, December 1989.

32. Iman, R. L., et al., "PARTITION: A Program for Defining the Source Term/Consequence Analysis Interface in the NUREG-1150 Probabilistic Risk Assessments, User's Guide," Sandia National Laboratories, NUREG/CR-5253, May 1990.

33. Chanin, D., J. Rollstin, J. Foster, and L. Miller, "MACCS Version 1.5.11.1: A Maintenance Release of the Code," NUREG/CR-6059, October 1993.

34. National Research Council Committee on Biological Effects of Ionizing Radiation (BEIR V), "Health Effects of Exposure to Low Levels of Ionizing Radiation," National Academy of Sciences, Washington, DC, 1990.

35. Iman, R. L., et al., "A FORTRAN 77 Program and Users Guide for the Generation of Latin Hypercube and Random Sampling Use with Computer Codes," Sandia National Laboratory, NUREG/CR-3624, March 1984. 


\section{APPENDIX}

APPROACHES FOR PERFORMING

A LEVEL 1 LOW POWER AND SHUTDOWN PRA 



\section{CONTENTS}

Page

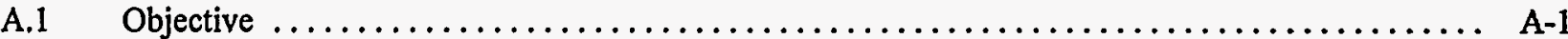

A.2 Characterization of Outages and Plant Operational States $\ldots \ldots \ldots \ldots \ldots \ldots \ldots \ldots \ldots \ldots$ A-1

A.3 Identification of Initiating Events and Accident Scenarios $\ldots \ldots \ldots \ldots \ldots \ldots \ldots \ldots \ldots \ldots \ldots$ A-9

A.3.1 Special Initiating Events or Issues to Be Addressed $\ldots \ldots \ldots \ldots \ldots \ldots \ldots \ldots \ldots \ldots \ldots \ldots \ldots$

A.4 Determination of Success Criteria and Time Windows $\ldots \ldots \ldots \ldots \ldots \ldots \ldots \ldots \ldots \ldots \ldots$ A-22

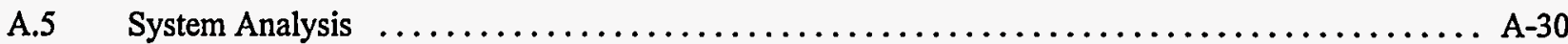

A.6 Development of Event Trees and Accident Scenarios $\ldots \ldots \ldots \ldots \ldots \ldots \ldots \ldots \ldots \ldots \ldots$ A-30

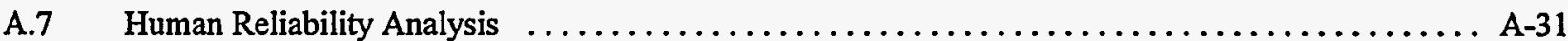

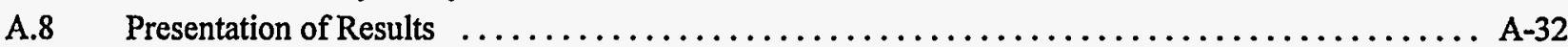

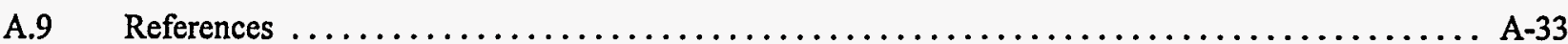

\section{FIGURES}

A.3-1 An Example Procedure Event Tree Taken from NSAC-84 $\ldots \ldots \ldots \ldots \ldots \ldots \ldots \ldots \ldots \ldots$ A-11

\section{TABLES}

A.2.1 List of Plant Information that Can Be Use to Identify and Characterize the Shutdown POSs $\ldots \ldots$ A-2

A.2.2 Parameters Used in the Definition and Characterization of POSs $\ldots \ldots \ldots \ldots \ldots \ldots \ldots \ldots \ldots$ A-3

A.2.3 Plant Operational States for a Refueling Outage at Surry Unit $1 \ldots \ldots \ldots \ldots \ldots \ldots \ldots \ldots \ldots$ A-5

A.2.4 Plant Operational States for a Refueling Outage at Grand Gulf $\ldots \ldots \ldots \ldots \ldots \ldots \ldots \ldots \ldots \ldots$ A-8

A.3.1 Approach Used in Identifying PWR Initiating Events $\ldots \ldots \ldots \ldots \ldots \ldots \ldots \ldots \ldots \ldots \ldots \ldots \ldots$

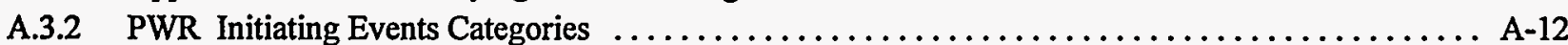

A.3.3 Estimated Initiating Event Frequency $\ldots \ldots \ldots \ldots \ldots \ldots \ldots \ldots \ldots \ldots \ldots \ldots \ldots \ldots \ldots \ldots \ldots$

A.3.4 References Used in Identifying BWR Initiating Events $\ldots \ldots \ldots \ldots \ldots \ldots \ldots \ldots \ldots \ldots \ldots \ldots \ldots$

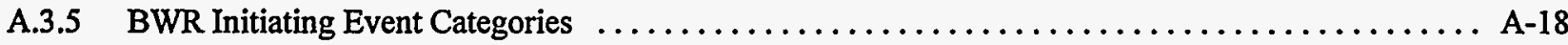

A.3.6 BWR Initiating Event Frequencies and Applicability to POSs $\ldots \ldots \ldots \ldots \ldots \ldots \ldots \ldots \ldots \ldots$ A-19

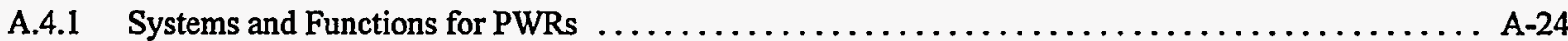

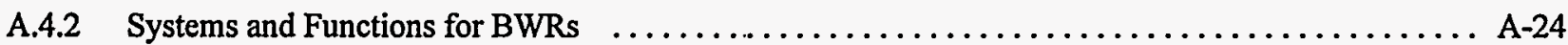

A.4.3 References to Thermal-Hydraulic Analyses for PWRs $\ldots \ldots \ldots \ldots \ldots \ldots \ldots \ldots \ldots \ldots \ldots \ldots$ A-25

A.4.4 Thermal-Hydraulic Analyses Performed for Reference [4] for Grand Gulf $\ldots \ldots \ldots \ldots \ldots \ldots \ldots$ A-26

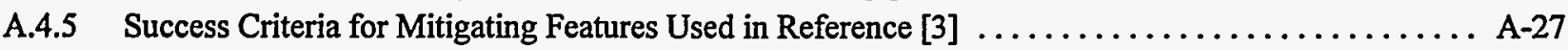

A.4.6 Definition and Characterization of Time Windows Used in Reference $[3] \ldots \ldots \ldots \ldots \ldots \ldots$ A-28 



\section{APPENDIX - APPROACHES FOR PERFORMING}

\section{A LEVEL 1 LOW POWER AND SHUTDOWN PRA}

\section{A.1 Objective}

The objective of this appendix is to provide a summary of the methods that can be used for performing a Level 1 LP\&S PRA. As guidance ${ }^{[1,2]}$ already exists for those methods typically used in performing a full power PRA, they will not be discussed in detail in this appendix. Only those methods that are unique to LP\&S conditions are discussed. It is assumed that the readers are PRA practitioners who are familiar with the methods used in performing a full power PRA. This appendix focuses on internal events only, excluding internal fires and floods. The approach for analyzing internal fires or floods is the same as that for a full power PRA. The only difference is that the event trees and fault trees developed during the internal event analysis for LP\&S conditions have to be used. This appendix is based on the methods used in the three latest LP\&S PRAs ${ }^{[3-5]}$ performed in the United States. In most cases, different methods exist for the tasks, and it is not possible at this time to prescribe the best method to use. Therefore, a few methods will be discussed with some comparison provided. The most important tasks of a shutdown PRA are identification of the shutdown configuration, and determination of success criteria and how they vary with decay heat. The documentation needed for each of the tasks for a LP\&S PRA is also discussed.

\section{A.2 Characterization of Outages and Plant Operational States}

Characterization of plant operational states defines the initial conditions for accident scenario development. Table A.2.1 lists the plant information that can be used to identify and characterize the shutdown POSs. The applications of each item to a shutdown PRA are also listed. Table A.2.2 lists important parameters that need to be determined for each POS and how they are used in a shutdown PRA. Tables A.2.3 and A.2.4 list the POSs defined for the Surry and Grand Gulf plants, respectively. 
Appendix

Table A.2.1 List of Plant Information That Can Be Used to Identify and Characterize the Shutdown POSs

\begin{tabular}{||l|l|l||}
\hline \multicolumn{1}{|c|}{ Plant Information } & \multicolumn{1}{|c|}{ Description } & \multicolumn{1}{c|}{ Application } \\
\hline \hline Outage Plan & $\begin{array}{l}\text { Planned major activities and plant } \\
\text { configurations during an outage }\end{array}$ & $\begin{array}{l}\text { 1. Definition of plant configuration } \\
\text { 2. Duration of POSs } \\
\text { 3. Maintenance unavailability }\end{array}$ \\
\hline $\begin{array}{l}\text { Shift Supervisor's Log } \\
\text { Books }\end{array}$ & $\begin{array}{l}\text { Actual detailed activities during an } \\
\text { outage, status of major components } \\
\text { and systems }\end{array}$ & $\begin{array}{l}\text { 1. Definition of plant configuration } \\
\text { 2. Duration of POSs } \\
\text { 3. Maintenance unavailability }\end{array}$ \\
\hline $\begin{array}{l}\text { Operating Procedures for } \\
\text { Shutdown Conditions }\end{array}$ & $\begin{array}{l}\text { Detailed steps of how operators } \\
\text { change the conditions of the plant }\end{array}$ & $\begin{array}{l}\text { 1. Definition of plant configuration } \\
\text { 2. Duration of POSs } \\
\text { 3. Maintenance unavailability } \\
\text { 4. Identification of initiating events }\end{array}$ \\
\hline $\begin{array}{l}\text { Test and Maintenance } \\
\text { Procedures }\end{array}$ & $\begin{array}{l}\text { Detailed steps of operators in } \\
\text { performing the test and maintenance }\end{array}$ & $\begin{array}{l}\text { 1. Maintenance unavailability } \\
\text { 2. Identification of initiating events } \\
\text { 3. Definition of plant configuration }\end{array}$ \\
\hline $\begin{array}{l}\text { Monthly Operating } \\
\text { Reports }\end{array}$ & $\begin{array}{l}\text { Actual timing of major activities and } \\
\text { plant configurations }\end{array}$ & $\begin{array}{l}\text { 1. Definition of plant configuration } \\
\text { 2. Duration of POSs }\end{array}$ \\
\hline $\begin{array}{l}\text { Minimum Equipment } \\
\text { Lists }\end{array}$ & Actual condition of major equipment & $\begin{array}{l}\text { 1. Definition of plant configuration } \\
\text { 2. Maintenance unavailability }\end{array}$ \\
\hline System Training Manual & $\begin{array}{l}\text { General discussion of conditions of } \\
\text { systems and components during } \\
\text { different plant conditions }\end{array}$ & $\begin{array}{l}\text { 1. Success criteria of systems } \\
\text { 2. Operability of systems in different } \\
\text { accident sequences in different POSs }\end{array}$ \\
\hline
\end{tabular}


Table A.2.2 Parameters Used in the Definition and Characterization of POSs

\begin{tabular}{|c|c|c|}
\hline Parameter & Source of Information & PRA Application \\
\hline Frequency & $\begin{array}{l}\text { Graybook, shift supervisor's log } \\
\text { books, outage plans }\end{array}$ & $\begin{array}{l}\text { Quantification of accident } \\
\text { scenarios }\end{array}$ \\
\hline Plant Configuration & $\begin{array}{l}\text { Operating procedures, shift } \\
\text { supervisor's log books }\end{array}$ & $\begin{array}{l}\text { Initial condition for accident } \\
\text { scenarios development }\end{array}$ \\
\hline System Availability & $\begin{array}{l}\text { Shift supervisor's log books, } \\
\text { system training manuals }\end{array}$ & Fault tree quantification \\
\hline Shutdown Activities & $\begin{array}{l}\text { Operating procedures, shift } \\
\text { supervisor's log books, outage plan }\end{array}$ & $\begin{array}{l}\text { Definition of POS Boundaries, } \\
\text { System availability }\end{array}$ \\
\hline Time to Core Uncovery/Damage & - & $\begin{array}{l}\text { Determination of success criteria, } \\
\text { quantification of HEPs }\end{array}$ \\
\hline Maintenance Unavailability & Shift supervisor's log books & Fault tree quantification \\
\hline RCS Integrity & $\begin{array}{l}\text { Operating procedures, shift } \\
\text { supervisor's log books, outage plan }\end{array}$ & Scenario development \\
\hline Containment Integrity & $\begin{array}{l}\text { Operating procedures, shift } \\
\text { supervisor's log books, outage plan }\end{array}$ & $\begin{array}{l}\text { Quantification of containment } \\
\text { event tree }\end{array}$ \\
\hline Reactivity & $\begin{array}{l}\text { Operating procedures, shift } \\
\text { supervisor's log books, outage plan }\end{array}$ & Scenario development \\
\hline Reactor Coolant Temperature & $\begin{array}{l}\text { Operating procedures, shift } \\
\text { supervisor's log books, outage plan }\end{array}$ & $\begin{array}{l}\text { Initial condition for accident } \\
\text { scenarios development }\end{array}$ \\
\hline Reactor Coolant Pressure & $\begin{array}{l}\text { Operating procedures, shift } \\
\text { supervisor's log books, outage plan }\end{array}$ & $\begin{array}{l}\text { Initial condition for accident } \\
\text { scenarios development }\end{array}$ \\
\hline Reactor Vessel Level & $\begin{array}{l}\text { Operating procedures, shift } \\
\text { supervisor's log books, outage plan }\end{array}$ & $\begin{array}{l}\text { Initial condition for accident } \\
\text { scenarios development }\end{array}$ \\
\hline Time after Shutdown & $\begin{array}{l}\text { Operating procedures, shift } \\
\text { supervisor's log books, outage plan }\end{array}$ & $\begin{array}{l}\text { Initial condition for accident } \\
\text { scenarios development }\end{array}$ \\
\hline Duration of POSs & $\begin{array}{l}\text { Operating procedures, shift } \\
\text { supervisor's log books, outage plan }\end{array}$ & $\begin{array}{l}\text { Quantification of accident } \\
\text { frequency }\end{array}$ \\
\hline
\end{tabular}


Table A.2.2 (continued)

\begin{tabular}{|c|c|c|}
\hline Parameter & Source of Information & PRA Application \\
\hline \multicolumn{3}{|c|}{ PWR POS Dependent Parameters } \\
\hline $\begin{array}{l}\text { Fraction of Time the Steam } \\
\text { Generators Are Drained }\end{array}$ & $\begin{array}{l}\text { Operating procedures, shift } \\
\text { supervisor's log books, outage plan }\end{array}$ & $\begin{array}{l}\text { Availability of steam generators as } \\
\text { a heat sink, definition of POS } \\
\text { boundaries }\end{array}$ \\
\hline $\begin{array}{l}\text { Fraction of Time the Steam } \\
\text { Generator Nozzle Dam Is in Place }\end{array}$ & $\begin{array}{l}\text { Operating procedures, shift } \\
\text { supervisor's log books, outage plan }\end{array}$ & $\begin{array}{l}\text { Quantification of accident } \\
\text { scenarios }\end{array}$ \\
\hline $\begin{array}{l}\text { Fraction of Time the Pressurizer } \\
\text { Safety Valves Are Removed }\end{array}$ & $\begin{array}{l}\text { Operating procedures, shift } \\
\text { supervisor's log books, outage plan, } \\
\text { test procedures }\end{array}$ & $\begin{array}{l}\text { Availability of reflux cooling and } \\
\text { gravity injection from RWST }\end{array}$ \\
\hline $\begin{array}{l}\text { Fraction of Time the RCS Loops } \\
\text { Are Isolated }\end{array}$ & $\begin{array}{l}\text { Operating procedures, shift } \\
\text { supervisor's log books, outage plan }\end{array}$ & $\begin{array}{l}\text { Availability of cooling using steam } \\
\text { generators, definition of POS } \\
\text { boundaries }\end{array}$ \\
\hline $\begin{array}{l}\text { Fraction of Time the Steam } \\
\text { Generator Manways Are Off }\end{array}$ & $\begin{array}{l}\text { Operating procedures, shift } \\
\text { supervisor's log books, outage plan }\end{array}$ & $\begin{array}{l}\text { Availability of cooling using steam } \\
\text { generators, definition of POS } \\
\text { boundaries }\end{array}$ \\
\hline $\begin{array}{l}\text { Fraction of Time the Vessel Head } \\
\text { Is Off }\end{array}$ & $\begin{array}{l}\text { Operating procedures, shift } \\
\text { supervisor's log books, outage plan }\end{array}$ & $\begin{array}{l}\text { Definition of POS boundaries, } \\
\text { quantification of accident scenarios }\end{array}$ \\
\hline \multicolumn{3}{|c|}{ BWR POS Dependent Parameters } \\
\hline $\begin{array}{l}\text { Fraction of Time the Hydraulic } \\
\text { Test Is in Progress }\end{array}$ & $\begin{array}{l}\text { Operating procedures, shift } \\
\text { supervisor's log books, outage plan }\end{array}$ & $\begin{array}{l}\text { Determination of initial conditions, } \\
\text { availability of safety relief valves }\end{array}$ \\
\hline $\begin{array}{l}\text { Fraction of Time the Suppression } \\
\text { Pool Is Empty }\end{array}$ & $\begin{array}{l}\text { Operating procedures, shift } \\
\text { supervisor's log books, outage plan }\end{array}$ & $\begin{array}{l}\text { Availability of suppression pool } \\
\text { function }\end{array}$ \\
\hline $\begin{array}{l}\text { Fraction of Time the Suppression } \\
\text { Pool Is at Reduced level }\end{array}$ & $\begin{array}{l}\text { Operating procedures, shift } \\
\text { supervisor's log books, outage plan }\end{array}$ & $\begin{array}{l}\text { Availability of suppression pool } \\
\text { function }\end{array}$ \\
\hline $\begin{array}{l}\text { Fraction of Time the Vessel Level } \\
\text { Is Sufficient for Natural } \\
\text { Recirculation Cooling }\end{array}$ & $\begin{array}{l}\text { Operating procedures, shift } \\
\text { supervisor's log books, outage plan }\end{array}$ & $\begin{array}{l}\text { Operability of natural recirculation } \\
\text { function }\end{array}$ \\
\hline $\begin{array}{l}\text { Fraction of Time the Vessel Level } \\
\text { Is Sufficient for Forced } \\
\text { Recirculation Cooling }\end{array}$ & $\begin{array}{l}\text { Operating procedures, shift } \\
\text { supervisor's log books, outage plan }\end{array}$ & $\begin{array}{l}\text { Operability of forced recirculation } \\
\text { function }\end{array}$ \\
\hline $\begin{array}{l}\text { Fraction of Time the Containment } \\
\text { Is Open }\end{array}$ & $\begin{array}{l}\text { Operating procedures, shift } \\
\text { supervisor's log books, outage plan }\end{array}$ & Control of radioactivity release \\
\hline
\end{tabular}


Table A.2.3 Plant Operational States for a Refueling Outage at Surry Unit 1

\begin{tabular}{|c|c|c|c|c|c|c|c|}
\hline & & Activities & Level & $\mathbf{K}$ & $\begin{array}{c}T \\
\left({ }^{\circ} \mathbf{F}\right)\end{array}$ & $\underset{\text { (psig) }}{\mathbf{P}}$ & $\begin{array}{l}\text { Standard } \\
\text { T.S. } \\
\text { Mode }\end{array}$ \\
\hline \multirow[t]{2}{*}{1} & $\begin{array}{l}\text { Low Power } \\
\text { Operation \& } \\
\text { RX } \\
\text { Shutdown }\end{array}$ & $\begin{array}{l}\text { - Transfer to manual RX } \\
\text { control } \\
\text { - Transfer to manual SG level } \\
\text { control }\end{array}$ & $\begin{array}{l}\text { In } \\
\text { Przr. }\end{array}$ & $\begin{array}{l}=1.0 \\
(<15 \% \\
\text { Power })\end{array}$ & 547 & 2235 & 1,2 \\
\hline & & & & $\leq 0.9823 \mathrm{TS}^{(3)}$ & 547 & 2235 & \\
\hline \multirow[t]{2}{*}{2} & $\begin{array}{l}\text { Cooldown } \\
\text { With SG }\end{array}$ & $\begin{array}{l}\text { - Borate RCS } \\
\text { - Stop } 2 \text { RCPs } \\
\text { - Block auto SI \& } \\
\text { accumulators } \\
\text { - Establish LTOP }<350^{\circ} \mathrm{F}\end{array}$ & & $<1.0$ & & & 3 \\
\hline & & & $\begin{array}{l}\text { In } \\
\text { Przr. }\end{array}$ & $<0.96 \mathrm{Adm}^{(4)}$ & 345 & 345 & \\
\hline \multirow[t]{2}{*}{3} & $\begin{array}{l}\text { Cooldown } \\
\text { With RHR }\end{array}$ & $\begin{array}{l}\text { - Disable Engineered } \\
\text { Safeguards } \\
\text { - Initiate RHR }\end{array}$ & & & & & 4 \\
\hline & & & $\begin{array}{l}\text { In } \\
\text { Przr. }\end{array}$ & $<0.96 \mathrm{Adm}^{(4)}$ & 200 & 345 & \\
\hline \multirow[t]{2}{*}{4} & $\begin{array}{l}\text { Cooldown } \\
\text { With RHR }\end{array}$ & $\begin{array}{l}\text { - No longer need Ctmt } \\
\text { Integrity } \\
\text { or Ctmt vacuum } \\
\text { - Secure SGs }\end{array}$ & & & & & 5 \\
\hline & & & $\begin{array}{l}\text { In } \\
\text { Przr. }\end{array}$ & $<0.96$ Adim $^{(4)}$ & 140 & 345 & \\
\hline \multirow[t]{2}{*}{5} & $\begin{array}{l}\text { Drain RCS } \\
\text { To Mid-loop }\end{array}$ & $\begin{array}{l}\text { - Deenergize Przr heaters } \\
\text { - Stop last RCP } \\
\text { - Cooldown Prar by fill up }\end{array}$ & & & & & 5,6 \\
\hline & & & $\begin{array}{l}\text { Mid- } \\
\text { loop }\end{array}$ & $<0.96 \mathrm{Adm}^{(4)}$ & $<140$ & 0 & \\
\hline \multirow[t]{2}{*}{6} & $\begin{array}{l}\text { Mid-loop } \\
\text { Operation }\end{array}$ & - Possible loop isolation & & & & & 5,6 \\
\hline & & & $\begin{array}{l}\text { Mid- } \\
\text { loop }\end{array}$ & $<0.96 \mathrm{Adm}^{(4)}$ & $<140$ & 0 & \\
\hline
\end{tabular}


Table A.2.3 (continued)

\begin{tabular}{|c|c|c|c|c|c|c|c|}
\hline & & Activities & Level & $\mathbf{K}$ & $\begin{array}{c}\mathrm{T} \\
\left({ }^{\circ} \mathrm{F}\right)\end{array}$ & $\begin{array}{c}\mathbf{P} \\
\text { (psig) }\end{array}$ & $\begin{array}{l}\text { Standard } \\
\text { T.S. } \\
\text { Mode }\end{array}$ \\
\hline \multirow[t]{2}{*}{7} & $\begin{array}{l}\text { Fill for } \\
\text { Refueling }\end{array}$ & $\begin{array}{l}\text { - Remove vessel head \& upper } \\
\text { internals structure } \\
\text { - Establish Refueling Ctmt } \\
\text { Integrity }\end{array}$ & & & & & 6 \\
\hline & & & $\begin{array}{l}\text { Refuel } \\
\text { Cavity } \\
\text { Full }\end{array}$ & $<0.95 \mathrm{TS}^{(2)}$ & $<140$ & 0 & \\
\hline \multirow[t]{2}{*}{8} & Refueling & $\begin{array}{l}\text { - Move fuel assemblies per } \\
\text { refueling sequence }\end{array}$ & & & & & 6 \\
\hline & & & $\begin{array}{l}\text { Refuel } \\
\text { Cavity } \\
\text { Full }\end{array}$ & $<0.95 \mathrm{TS}^{(3)}$ & $<140$ & 0 & \\
\hline \multirow[t]{2}{*}{9} & $\begin{array}{l}\text { Drain RCS to } \\
\text { Mid-loop } \\
\text { After } \\
\text { Refueling }\end{array}$ & $\begin{array}{l}\text { - Install vessel upper internals } \\
\text { structure \& head } \\
\text { - No longer need Refueling } \\
\text { Ctmt. } \\
\text { Integrity }\end{array}$ & & & & & 6 \\
\hline & & & $\begin{array}{l}\text { Mid- } \\
\text { loop }\end{array}$ & $0.96 \mathrm{Adm}^{(4)}$ & $<140$ & 0 & \\
\hline \multirow[t]{2}{*}{10} & $\begin{array}{l}\text { Mid-loop } \\
\text { Operation } \\
\text { After } \\
\text { Refueling }\end{array}$ & $\begin{array}{l}\text { - Possible further loop } \\
\text { isolation }\end{array}$ & & & & & 5,6 \\
\hline & & & $\begin{array}{l}\text { Mid- } \\
\text { loop }\end{array}$ & $<0.96 \mathrm{Adm}^{(4)}$ & $<140$ & 0 & \\
\hline \multirow[t]{2}{*}{11} & $\begin{array}{l}\text { Refill RCS } \\
\text { completely }\end{array}$ & $\begin{array}{l}\text { - Pressurize RCS \& jog RCP } \\
\text { for RCS vent \& Fill } \\
\text { - Unisolate any and all loops }\end{array}$ & & & & & 5,6 \\
\hline & & . & $\begin{array}{l}\text { RCS } \\
\text { Full }\end{array}$ & $<0.96 \mathrm{Adm}^{(4)}$ & $<140$ & $<125$ & \\
\hline \multirow[t]{2}{*}{12} & $\begin{array}{l}\text { RCS Heatup } \\
\text { Solid and } \\
\text { Draw Bubble }\end{array}$ & $\begin{array}{l}\text { - Pressurize RCS, start RCP } \\
\text { \& energize Przr. htrs } \\
\text { - Establish Ctmt. Integrity and } \\
\text { Ctmt. vacuum }\end{array}$ & & & & & 5 \\
\hline & & & $\begin{array}{l}\text { In } \\
\text { Przr. }\end{array}$ & $<0.98 \mathrm{Adm}^{(4)}$ & 200 & 345 & \\
\hline
\end{tabular}


Table A.2.3 (continued)

\begin{tabular}{|c|c|c|c|c|c|c|c|}
\hline & & Activities & Level & $\mathbf{K}$ & $\begin{array}{c}\mathrm{T} \\
\left({ }^{\circ} \mathbf{F}\right)\end{array}$ & $\underset{\text { (psig) }}{\mathbf{P}}$ & $\begin{array}{c}\text { Standard } \\
\text { T.S. } \\
\text { Mode }\end{array}$ \\
\hline \multirow[t]{2}{*}{13} & RCS Heatup & $\begin{array}{l}\text { - Start other RCPs } \\
\text { - Enable Engineered } \\
\text { Safeguards } \\
\text { - Secure RHR }\end{array}$ & & & & & $\overline{4}$ \\
\hline & $\cdot$ & & $\begin{array}{l}\text { In } \\
\text { Przr. }\end{array}$ & $<0.9823 \mathrm{TS}^{(3)}$ & 350 & $\approx 345$ & \\
\hline \multirow[t]{2}{*}{14} & $\begin{array}{l}\text { RCS Heatup } \\
\text { With } \\
\text { SGs }\end{array}$ & $\begin{array}{l}\text { - Flow test MDAFWs } \\
\text { - Disable LTOP protection } \\
>350^{\circ} \mathrm{F} \\
\text { - Unblock accumulators } \\
\text { - Verify auto SI reestablished } \\
\text { - Dilute RCS }\end{array}$ & & $<1.0$ & & & 3 \\
\hline & & & $\begin{array}{c}\text { In } \\
\text { Przr. }\end{array}$ & $\leq 0.9823 \mathrm{TS}^{(3)}$ & 547 & 2235 & \\
\hline 15 & $\begin{array}{l}\text { RX Startup } \\
\text { \& Low } \\
\text { Power } \\
\text { Operation }\end{array}$ & $\begin{array}{l}\text { - Flow test TDAFW } \\
\text { - Transfer to auto SG level } \\
\text { - Transfer to auto RX control }\end{array}$ & & $\begin{array}{l}=1.0 \\
(<15 \% \\
\text { power })\end{array}$ & 547 & 2235 & 1,2 \\
\hline
\end{tabular}

(1) The time is based on the October 1986 refueling outage of Unit 2. Both duration of POS and cumulative time after shutdown are shown.

(2) The operating procedures listed are based on the most updated information as of yet. Some of these procedures' numberings are different from those prevailing in October 1986.

(3) Shutdown Margin Requirements - Per Technical Specifications (1.0 Definitions)

$\operatorname{CSD}$ (Cold Shutdown) Condition $-\mathrm{RX}$ subcritical by at least $1 \% \Delta \mathrm{K} / \mathrm{K}(\therefore \mathrm{K} \leq \approx 0.99)$ and Tavg is $\leq 200^{\circ} \mathrm{F}$. ISD(Intermediate Shutdown) Condition - RX subcritical by $\geq 1.77 \% \Delta \mathrm{K} / \mathrm{K}(. \mathrm{K} \leq \approx 0.9823)$ and Tavg is $>200^{\circ} \mathrm{F}$ but $<547^{\circ} \mathrm{F}$.

HSD(Hot Shutdown) Condition - $\mathrm{RX}$ subcritical by $\geq 1.77 \% \Delta \mathrm{K} / \mathrm{K}(. \mathrm{K} \leq \approx 0.9823)$ and Tavg is $>547^{\circ} \mathrm{F}$.

(4) Shutdown Margin Administrative Limits - Per 1-OP-1C, Shutdown Margin Calculation

A further requirement states that except for during the approach to criticality, the minimum boron concentration allowed in a shutdown core must be the greater of the following:

Critical Boron for the $0 \%$ power insertion limit $\underline{O R}$

The boron required to maintain the administratively $\left(\mathrm{Adm}^{*}\right)$ required shutdown margin $>5500 \mathrm{pcm}(\mathrm{K}=0.945)$ from BOL (beginning of life) to $9000 \mathrm{MWD} / \mathrm{MTU}$ and $>4000 \mathrm{pcm}(\mathrm{K}<\approx 0.960)$ after $9000 \mathrm{MWD} / \mathrm{MTU}$.

(5) As in the recently implemented OP-RC-005, before entering Reduced Inventory within 150 hours of shutdown, containment integrity must be established.

Vol. 1 


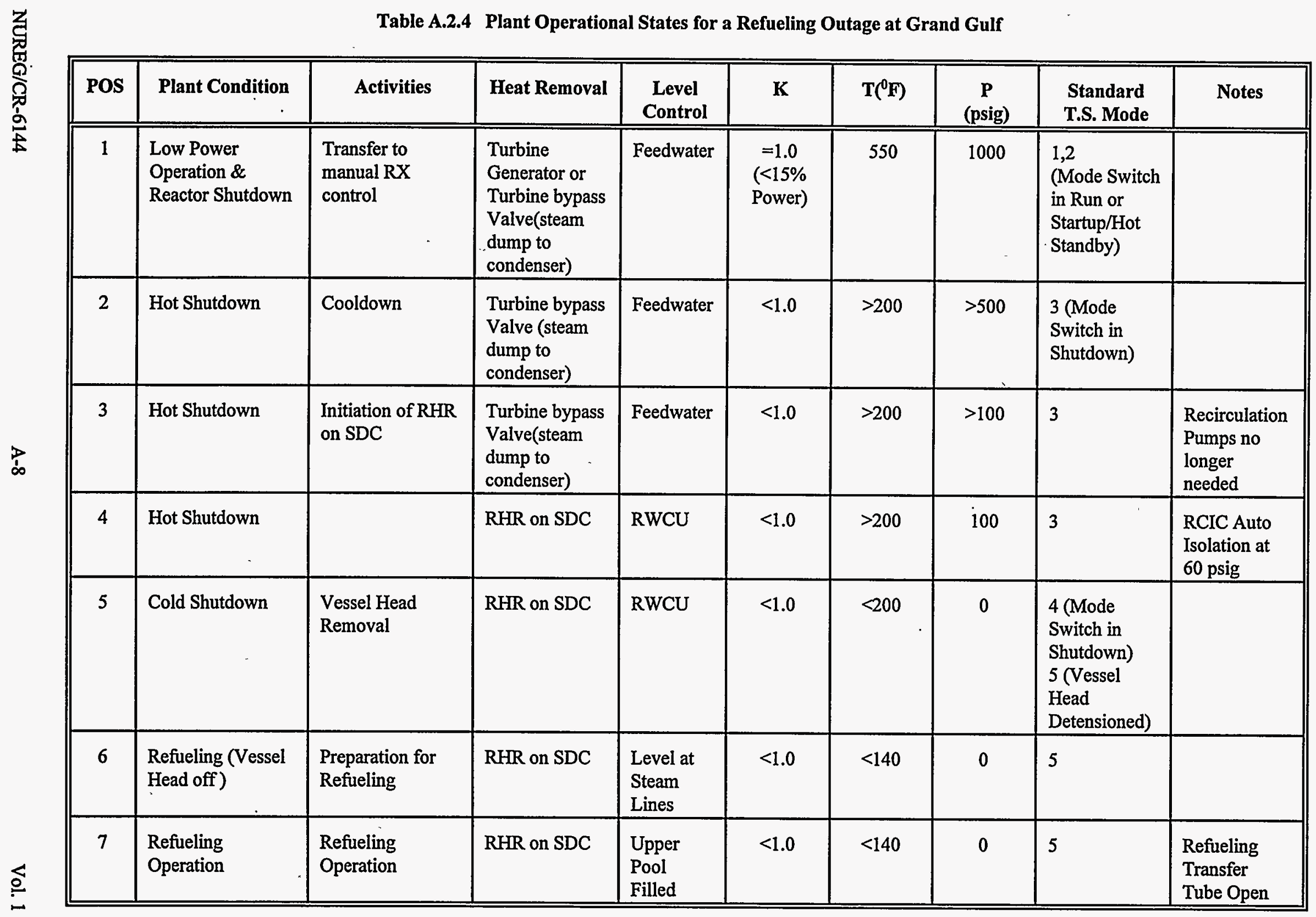




\section{A.3 Identification of Initiating Events and Accident Scenarios}

\section{Definition of Initiating Event}

An initiating event during shutdown can be defined as one of the following:

- loss of decay heat removal,

- pressure transient that can potentially challenge the RCS integrity,

- loss of RCS inventory,

- and reactivity transients.

Two approaches have been used in identifying and quantifying the initiating events. They are discussed below:

\section{(1) Data Analysis Approach}

References [3] and [4] used an approach in which data on incidents that have actually occurred, and studies of accident scenarios that have been identified were reviewed in order to identify initiating events. The collected data was used to estimate the frequencies of the initiating events. Table A.3.1 summarizes the approach used in identifying accident initiating events that may occur at PWRs and provides references to relevant documents. Table A.3.2 lists the initiating events of a PWR. Table A.3.3 lists the POS specific initiating event frequencies for a PWR. Tables A.3.4 to A.3.6 provide similar information for a BWR.

\section{(2) Procedure Event Tree Approach}

References [5] and [6] used the procedure event tree approach to define and quantify initiating events. Figure A.31 is an example of such an event tree. The top events of the trees are either major operator actions identified in the operating procedures for shutdown conditions or failure of hardware used during shutdown conditions. Failure of the operator or hardware may lead to different types of initiating events represented by the sequences in the procedure event tree. The failure probability of the operator is quantified using an applicable human reliability analysis approach, and hardware failure is modeled by fault trees with component hardware failure data. The end states of the procedure event trees transfer to the applicable accident event trees that model the mitigation of the accidents.

\section{A.3.1 Special Initiating Events or Issues to Be Addressed}

\section{RCS Pressure Relief Capability}

During an outage, the relief valves that can potentially relieve RCS pressure have to be identified and their capacity evaluated for the shutdown condition. Typically for a PWR, the PORVs, and possibly the RHR relieve valve and the relief valves in the letdown flow path, can relieve pressure during shutdown. Whether or not the valves are available in different accident scenarios has to be evaluated. 
Appendix

Weakness in RCS Pressure Boundary

During an outage (for some plants), a weakness in the RCS pressure boundary may be introduced, e.g., steam generator nozzle dam or thimble tube seals for PWRs. Any such weakness has to be specifically addressed in the PRA. Two types of scenarios are possible: (1) failure of the weakness as an initiating event and (2) failure as a result of some other scenarios that challenge the pressure boundary. Both possibilities have to be developed and quantified. When identifying weakness in the RCS pressure boundary, all systems and components that may be connected to the RCS should be taken into consideration. For example, the residual heat removal system at PWRs has a design pressure that is significantly lower than that of the RCS. In Appendix I of Reference [3], scenarios involving challenges to the RHR system were identified. In those scenarios, the RCS pressure may exceed the design pressure of the RHR even if the PORVs and RHR relief valve are operable.

\section{French Scenario}

Reference [7] identified a fast reactivity accident scenario that may occur during de-boration. Reference [8] evaluated the scenario for three PWRs and took into consideration a number of deterministic issues, such as reactivity effects and mixing of the injected unborated water with the reactor coolant. It was found that the mixing issue cannot be easily resolved and depends on the geometry of the connection between the injection line and the cold leg. This scenario has to be evaluated on a plant-by-plant basis.

\section{Adverse Configuration}

Reference [9] identified a plant configuration during shutdown that has the potential for rapid core uncovery as a result of loss of RHR. In this configuration, the hot legs are isolated and an opening or weakness in the pressure boundary exists in the cold leg. A small pressure increase in the RCS can push the coolant out of the vessel and uncover the core. Generic Letter $88-17^{[10]}$ specifically addresses this issue and requires the plants to implement protection against the scenario. Each plant's implementation has to be evaluated in terms of the its effectiveness against the likelihood of the scenario.

\section{Reactivity Accidents}

Reference [11] evaluated different categories of reactivity accidents for PWRs and BWRs. The following scenarios are judged to be significant and should be analyzed based on plant specific design:

- PWR-French scenario

- PWR-LOCA/SGTR with the secondary side coolant diluting the primary coolant

- $\quad$ BWR-Flushing of boron during an ATWS

- $\quad$ BWR-Reactivity event initiated while in unstable operation

- $\quad$ BWR-Refueling Accident

Spent Fuel Pool Accident

NUREG/CR-4982 ${ }^{[12]}$ addresses spent fuel pool accidents and identifies failure of the refueling cavity seals and a fuel transfer cask drop as potential accident scenarios during a refueling outage. 
Figure A.3-1 An Example Procedure Event Tree Taken from NSAC-84

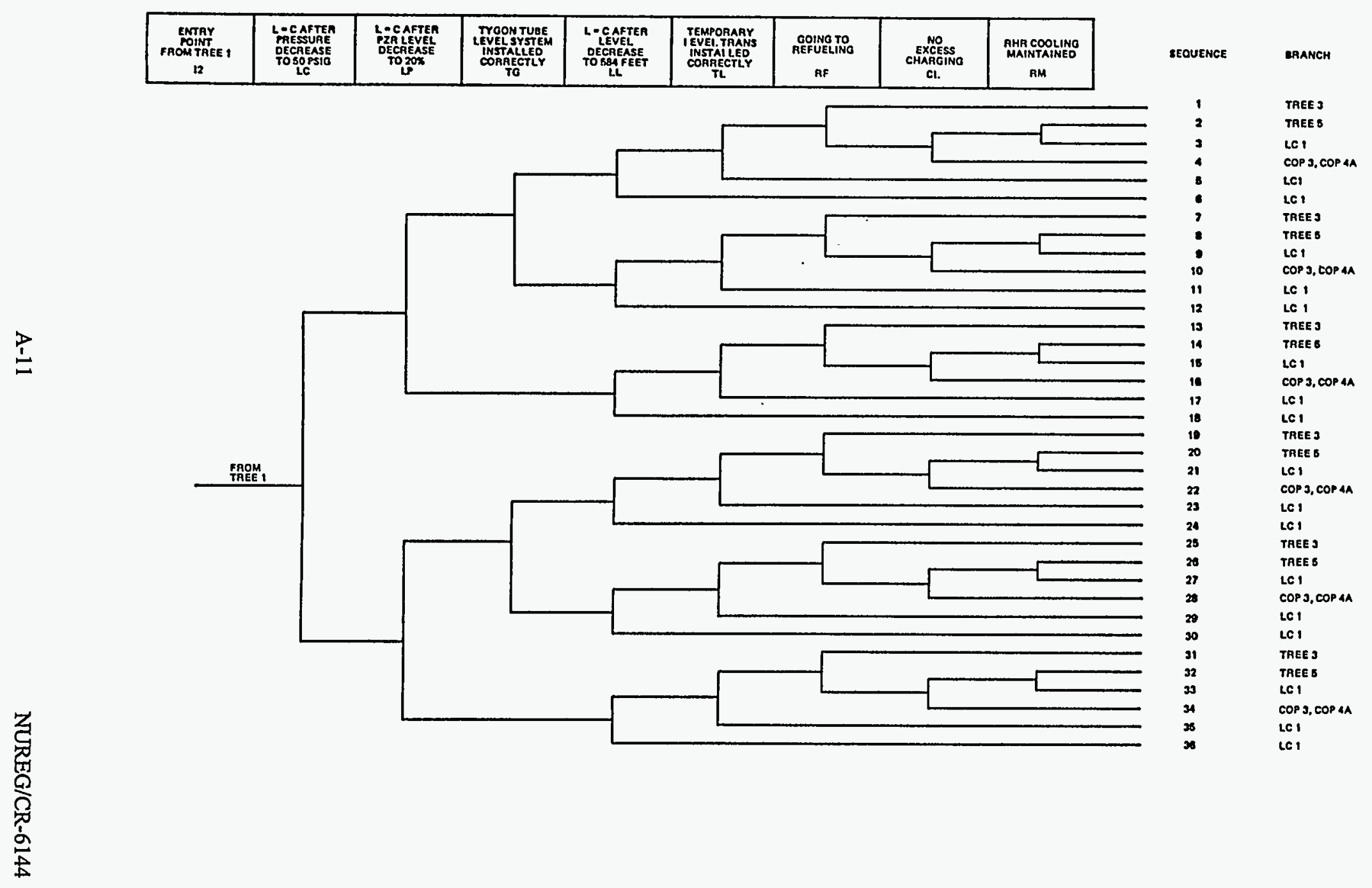


Table A.3.1 Approach Used in Identifying PWR Initiating Events

\begin{tabular}{|c|c|c|}
\hline \multirow[t]{4}{*}{ I. } & \multicolumn{2}{|c|}{ Loss of RHR Events } \\
\hline & \multicolumn{2}{|c|}{ Review of Shutdown Incident Reports } \\
\hline & \multicolumn{2}{|c|}{ NSAC-52, AEOD/C503, Seabrook Shutdown Study } \\
\hline & \multicolumn{2}{|c|}{ Search of Computerized Data Base-Sequence Coding Search System } \\
\hline \multirow[t]{2}{*}{ II. } & \multicolumn{2}{|c|}{ Review of Existing Shutdown Studies } \\
\hline & \multicolumn{2}{|c|}{ NSAC-84, Seabrook, French Study, NUREG/CR-5015 } \\
\hline \multirow[t]{2}{*}{ III. } & \multicolumn{2}{|c|}{ Review of Procedures Used at Shutdown } \\
\hline & \multicolumn{2}{|c|}{ Operating Procedure, Test Procedure, Maintenance Procedure } \\
\hline \multirow[t]{4}{*}{ IV. } & \multicolumn{2}{|c|}{ Review of Initiating Events for Power Operations } \\
\hline & \multicolumn{2}{|c|}{ NUREG/CR-4550 Volume 1 , Generic Transients for PWRs } \\
\hline & \multicolumn{2}{|c|}{ NUREG/CR-4550 Volume 3, Support System Failures, Subtle Interactions } \\
\hline & \multicolumn{2}{|c|}{ Surry Probabilistic Risk Assessment for the Individual Plant Examination } \\
\hline V. & \multicolumn{2}{|c|}{ Review of NRC Generic Letters, Information Notices, Bulletin, circulars } \\
\hline \multirow[t]{9}{*}{ VI. } & \multicolumn{2}{|c|}{ Review of Other Studies That Identified Scenarios at Shutdown } \\
\hline & NUREG/CR-4999 & Low Temperature Over Pressurization \\
\hline & NUREG/CR-5368 & Reactivity Accidents \\
\hline & NUREG-1269 & Diablo Canyon Incident Augmentèd Investigation \\
\hline & & Team Report \\
\hline & NUREG-1410 & Votgle Incident Investigation Team Report \\
\hline & WCAP-11916 & Loss of RHRS While the RCS is Partially Filled \\
\hline & & Westinghouse PRA of LOCAs in Modes 3 and 4 \\
\hline & NUREG/CR-4407 & Pipe Break Frequency Estimation for NPP \\
\hline
\end{tabular}


Table A.3.2 PWR Initiating Events Categories

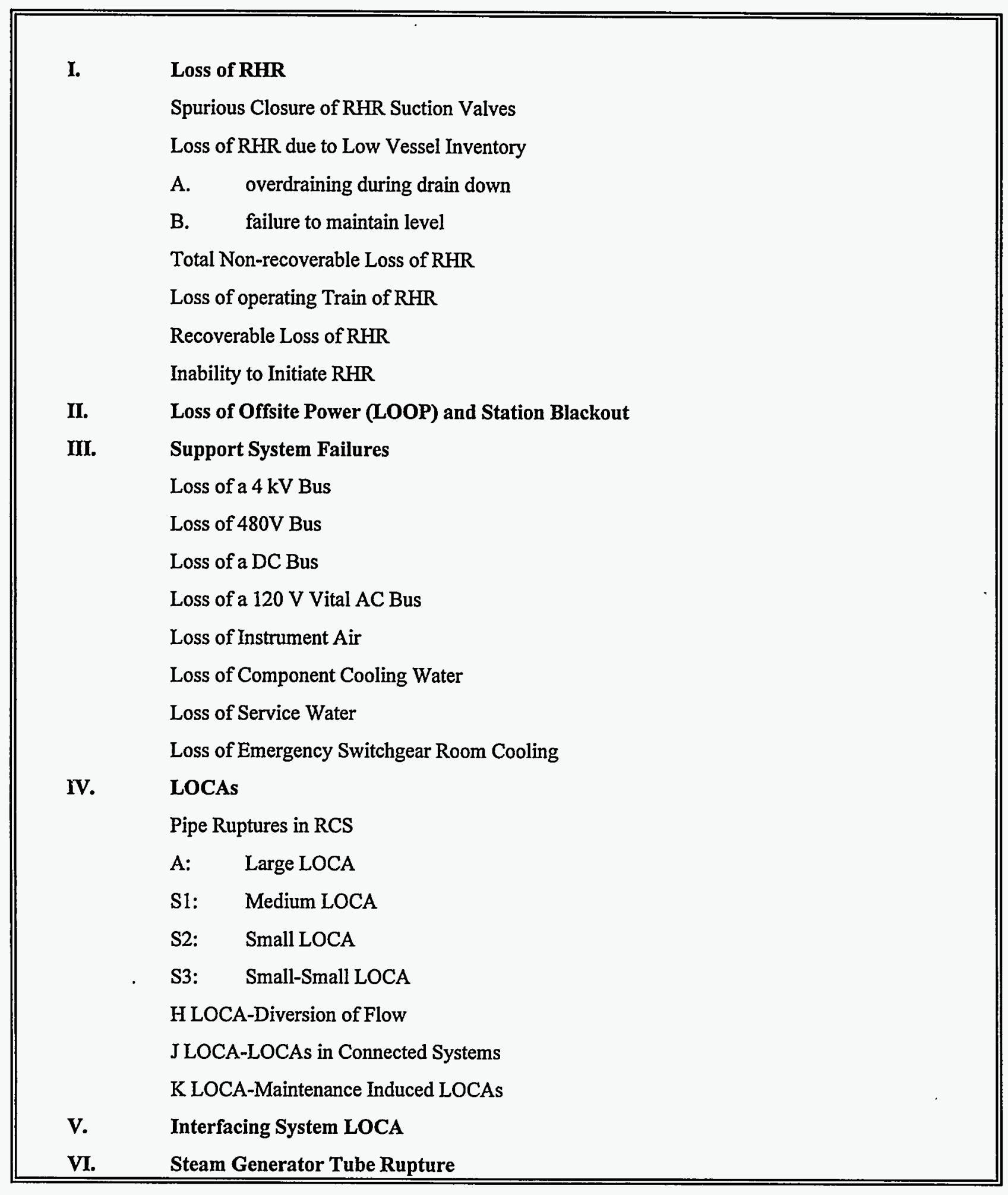

Vol. 1 
Appendix

Table A.3.2 (continued)

\begin{tabular}{|ll|}
\hline VII. & Inadvertent Safety Feature Actuation \\
VII. & Transients \\
& Transient with loss of MFW (no challenge to RPS) \\
& Transient with loss of MFW (challenge to RPS) \\
& Transient with MFW Available (no challenge to RPS) \\
& Transient with MFW Available (challenge to RPS) \\
IX. & Pressurized Thermal Shock \\
X. & Reactivity Accidents \\
& Addition of Diluted Accumulator Water \\
& Addition of Diluted RWST Water \\
& Dilution When Cleaning Cavity \\
& Dilution due to Steam Generator Maintenance \\
& Uncontrolled Boron Dilution from CVCS \\
& Boron Dilution via RHR \\
Startup of RCP after Improper Boron Dilution \\
Backfill Cooldown after STGR \\
Rod Ejection \\
Misloading of Fuel Assembly \\
Uncontrolled Bank Withdraw \\
Heavy Load Drop Accident \\
\\
\end{tabular}


Table A.3.3 Estimated Initiating Event Frequency

I. Loss of RHR

\begin{tabular}{|c|c|c|}
\hline & Mean Value & Error Factor \\
\hline \hline & N.A. & \\
\hline RHR2A & $1.62 \mathrm{E}-02 / \mathrm{DEM}$ AND & 1.97 \\
\hline RHR2B & $1.220 \mathrm{E}-05 / \mathrm{hr}$ & 3.27 \\
\hline RHR3 & $4.09 \mathrm{E}-06 / \mathrm{hr}$ & 3.79 \\
\hline RHR4 & $5.28 \mathrm{E}-06 / \mathrm{hr}$ & 3.82 \\
\hline RHR5 & $2.12 \mathrm{E}-05 / \mathrm{hr}$ & 2.21 \\
\hline RHR6 & $1.29 \mathrm{E}-02 / \mathrm{DEMAND}$ & 1.54 \\
\hline
\end{tabular}

II. LOOP

POS 1,15 POS 2-14

$9.13 \mathrm{E}-6 / \mathrm{hr} \quad 6.96 \mathrm{E}-6 / \mathrm{hr}$

III. Support System Failures

\begin{tabular}{||l|c|c||}
\hline & Mean & Error Factor \\
\hline \hline Loss of a 4 kV Bus (4 kV) & & \\
POS 6,10 & $2.10 \mathrm{E}-05 / \mathrm{hr}$ & 2.4 \\
POS 3,4,5,8,9,11,12,13 & $2.63 \mathrm{E}-05 / \mathrm{hr}$ & 2.14 \\
\hline Loss of a 120 V Vital & $5.58 \mathrm{E}-06 / \mathrm{hr}$ & 3.94 \\
\hline Loss of Instrument Air-Outside Containment & $2.12 \mathrm{E}-06 / \mathrm{hr}$ & 2.86 \\
\hline Loss of Component Cooling Water & $3.76 \mathrm{E}-06 / \mathrm{hr}$ & 6.35 \\
\hline Loss of Emergency & & \\
Switchgear Room Cooling & & \\
POS 6,10 & $1.81 \mathrm{E}-08 / \mathrm{hr}$ & 4.0 \\
POS 3,4,5,7,8,9,11,12,13 & $6.13 \mathrm{E}-08 / \mathrm{hr}$ & 4.0 \\
\hline
\end{tabular}

Vol. 1 
Appendix

Table A.3.3 (continued)

IV. Loss of Coolant Accident

\begin{tabular}{||c|c|c|c||}
\hline & POS 1 \& 15 & POS 2 \& 14 & POS 3,4,12,13 \\
\hline \hline A & $5.0 \mathrm{E}-4 / \mathrm{y}$ & $2.5 \mathrm{E}-5 / \mathrm{y}$ & $1.7 \mathrm{E}-5 / \mathrm{y}$ \\
\hline S1 & $1.0 \mathrm{E}-3 / \mathrm{y}$ & $5.0 \mathrm{E}-5 / \mathrm{y}$ & $3.3 \mathrm{E}-5 / \mathrm{y}$ \\
\hline S2 & $1.0 \mathrm{E}-3 / \mathrm{y}$ & $6.0 \mathrm{E}-5 / \mathrm{y}$ & $3.3 \mathrm{E}-5 / \mathrm{y}$ \\
\hline S3 & $1.3 \mathrm{E}-3 / \mathrm{y}$ & $6.5 \mathrm{E}-4 / \mathrm{y}$ & $4.3 \mathrm{E}-4 / \mathrm{y}$ \\
\hline
\end{tabular}

$\mathrm{H}$ - Recoverable Flow Diversion

via $\mathrm{RHR} \quad 5.0 \mathrm{E}-3 / \mathrm{y}$

via CVCS $\quad 1.0 \mathrm{E}-3 / \mathrm{y}$

Drain

Valves $\quad 1.0 \mathrm{E}-3 / \mathrm{y}$

$\mathrm{J}$ - LOCAs in Connected System

via RHR $\quad 5.0 \mathrm{E}-3 / \mathrm{y}$

via CVCS 3.0E-3/y

K - Maintenance Induced LOCA

via $\mathrm{RCS} 2.0 \mathrm{E}-3 / \mathrm{y}$

via $\mathrm{RHR} \quad 1.0 \mathrm{E}-3 / \mathrm{y}$

V. Interfacing LOCA

\begin{tabular}{||l|c|c|c|c||}
\hline & POS 1 & POS 2 & POS 14 & POS 15 \\
\hline \hline LPSI (CDF) & $3.00 \mathrm{E}-10 / \mathrm{y}$ & $8.90 \mathrm{E}-9 / \mathrm{y}$ & $1.22 \mathrm{E}-08 / \mathrm{y}$ & $1.00 \mathrm{E}-08 / \mathrm{y}$ \\
\hline $\begin{array}{l}\text { RHR Suction \& } \\
\text { Discharge (CDF) }\end{array}$ & $3.2 \mathrm{E}-8 / \mathrm{y}$ & $9.3 \mathrm{E}-7 / \mathrm{y}$ & $1.28 \mathrm{E}-6 / \mathrm{y}$ & $1.0 \mathrm{E}-6 / \mathrm{y}$. \\
\hline RHR-CVCS (CDF) & $3.2 \mathrm{E}-12 / \mathrm{y}$ & $9.56-11 / \mathrm{y}$ & $1.31-10 \mathrm{y}$ & $1.1 \mathrm{E}-10 / \mathrm{y}$ \\
\hline ACC & $1.83-7 / \mathrm{y}$ & $5.44-6 / \mathrm{y}$ & $7.44-5 / \mathrm{y}$ & $6.11 \mathrm{E}-6 / \mathrm{y}$ \\
\hline
\end{tabular}

\begin{tabular}{|l|c|c|c||}
\hline & POS 3 & POS 4 & POS 12, 13 \\
\hline \hline RHR-RWST (CDF) & $2.38-8 / y$ & $2.92-7 / \mathrm{y}$ & $9.15-7 / \mathrm{y}$ \\
\hline
\end{tabular}


Table A.3.3 (continued)

VI. Steam Generator Tube Rupture POSs $1,2,14,15 \quad 1.00 \mathrm{E}-02 / \mathrm{yr}$

POSs $3,4,12,13 \quad 1.00 \mathrm{E}-03 / \mathrm{yr}$

VII. Inadvertent Safety Feature Actuation

Mean

Error Factor

$1.06 \mathrm{E}-04 / \mathrm{hr}$

1.15

VIII.

$\mathrm{T} 2$

$\mathrm{T} 2 \mathrm{a}$

Transients

T3

. $-3 / \mathrm{hr}$

$1.82 \mathrm{E}-3 / \mathrm{hr}$

T3a

$1.24 \mathrm{E}-3 / \mathrm{hr}$

8.3E-3/hr

LTOP

Mean Error Factor

POS $3,4,12,13 \quad 1.06 \mathrm{E}-04 / \mathrm{hr} \quad 1.15$

IX. Pressurized Thermal Shock (CDF) 1.05E-07/y

X. Reactivity Accidents (CDF)

Accumulator

RWST

CVCS (French)

RCP (French)

Refueling
$8.0 \mathrm{E}-10 / \mathrm{y}$

$2.5 \mathrm{E}-10 / \mathrm{y}$

$6.8 \mathrm{E}-08 / \mathrm{y}$

$2.8 \mathrm{E}-05 / \mathrm{y}$

$1.2 \mathrm{E}-07 / \mathrm{y}$

Vol. 1 
Appendix

Table A.3.4 References Used in Identifying BWR Initiating Events

\begin{tabular}{|c|c|}
\hline 1. & $\begin{array}{l}\text { M.T. Drouin et al.,"Analysis of Core Damage Frequency: Grand Gulf, Unit 1; Internal Events," } \\
\text { NUREG/CR-4550, SAND86-2084, Vol. 6, Rev. 1, Part 1, September } 1989 .\end{array}$ \\
\hline 2. & $\begin{array}{l}\text { D.J. Diamond et al., "Reactivity Accidents: A Reassessment of the Design-Basis Events," } \\
\text { NUREG/CR-5368, BNL-NUREG- 52198, September } 1989 .\end{array}$ \\
\hline 3. & $\begin{array}{l}\text { D.P. Mackowiak et al., "Development of Transient Initiating Event Frequencies for Use in } \\
\text { Probabilistic Risk Assessments," NUREG/CR-3862, EGG-2323, May } 1985 .\end{array}$ \\
\hline 4 & $\begin{array}{l}\text { H. R. Booth, “Analysis of Refueling Incidents in Nuclear Power Plants," NSAC-129, } \\
\text { December 1988. }\end{array}$ \\
\hline 5. & $\begin{array}{l}\text { D. M. Ericson, ed., “Analysis of Core Damage Frequency: Internal Events Methodology,” } \\
\text { NUREG/CR-4550, SAND86-2084, Vol. 1, Rev. 1, January } 1990 .\end{array}$ \\
\hline 6. & $\begin{array}{l}\text { R.E. Wright et al., "Pipe Break Frequency Estimation for Nuclear Power Plants," } \\
\text { NUREG/CR-4407, EGG-2421, May } 1987 .\end{array}$ \\
\hline 7. & $\begin{array}{l}\text { G. Vine et al., "Residual Heat Removal Experience Review and Safety Analysis: Boiling Water } \\
\text { Reactors," NSAC-88, March } 1986 .\end{array}$ \\
\hline 8. & $\begin{array}{l}\text { T. A. Wheeler et al., "Analysis of Core Damage Frequency From Internal Events: Expert } \\
\text { Judgment Elicitation," NUREG/CR-4550, SAND86-2084, Vol. 2, April } 1989 .\end{array}$ \\
\hline 9. & $\begin{array}{l}\text { D. W. Whitehead, J. L. Darby, B. D. Staple, B. Walsh, T. M. Hake, and T. D. Brown, "BWR Low } \\
\text { Power and Shutdown Accident Frequencies Project, Phase } 1 \text { - Coarse Screening Analysis," Vol. 1, } \\
\text { Draft Letter Report, Sandia National Laboratories and Science and Engineering Associates, Inc., } \\
\text { November 23, } 1991 \text { update, (Available at the USNRC Public Document Room). }\end{array}$ \\
\hline 10. & $\begin{array}{l}\text { P. Lam et al., "Operating Experience Feedback Report - Service Water System Failures and } \\
\text { Degradation," NUREG-1275, Vol. 3, November } 1988 .\end{array}$ \\
\hline
\end{tabular}


Table A.3.5 BWR Initiating Event Categories

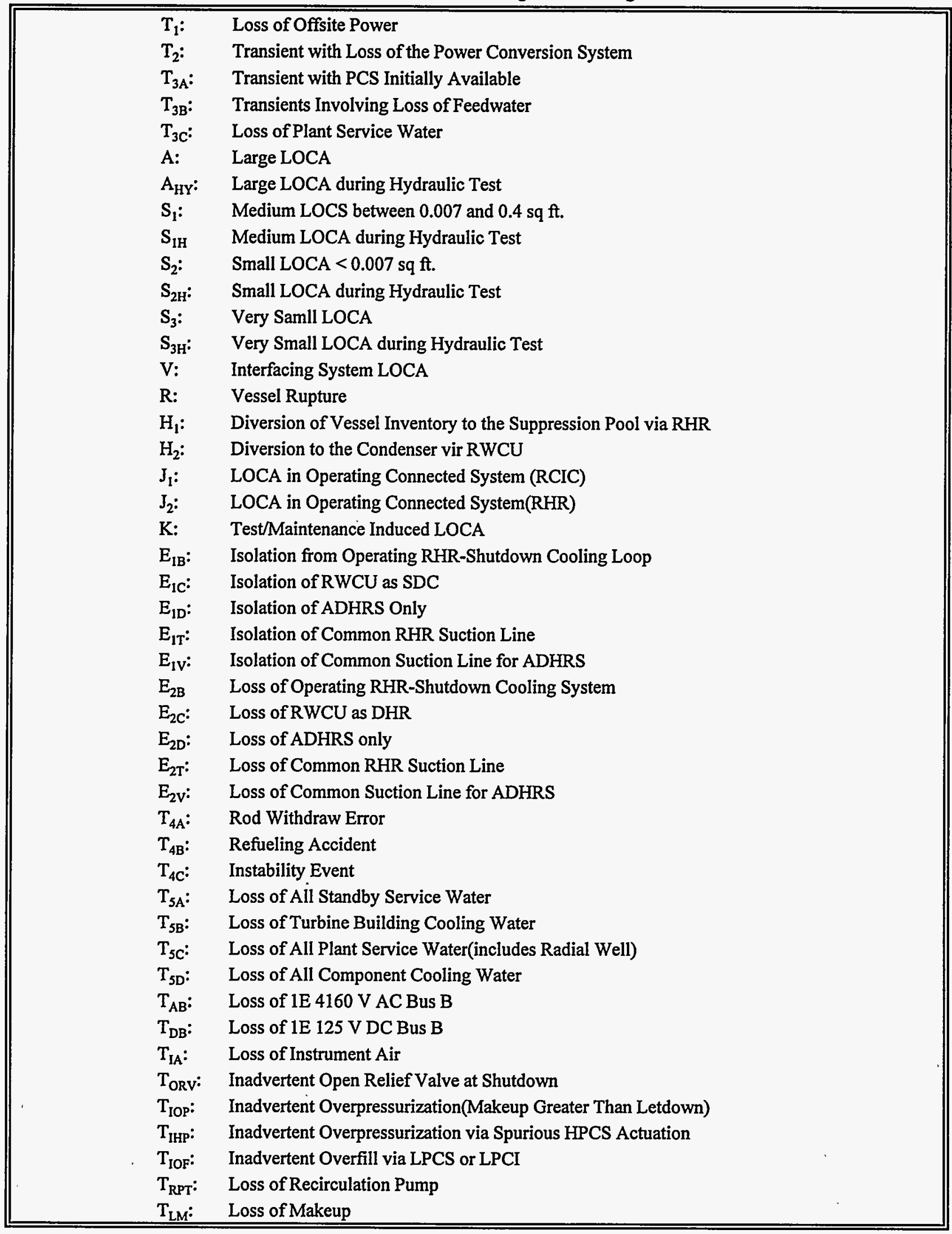


Appendix

Table A.3.6 BWR Initiating Event Frequencies and Applicability to POSs

\begin{tabular}{|c|c|c|c|c|c|c|c|}
\hline Initiator & POS 1 & POS 2 & POS 3 & POS 4 & POS 5 & POS 6 & POS 7 \\
\hline $\mathrm{T}_{1}$ & 0.07 & 0.13 & 0.13 & 0.13 & 0.13 & 0.13 & 0.13 \\
\hline$T_{2}$ & 1.63 & 0.44 & 0.44 & $\mathrm{NA}$ & NA & NA & NA \\
\hline $\mathrm{T}_{3 \mathrm{~A}}$ & 4.54 & 1.00 & 1.00 & NA & NA & NA & NA \\
\hline $\mathrm{T}_{3 \mathrm{~B}}$ & 1.06 & 0.25 & 0.25 & NA & NA & NA & NA \\
\hline $\mathrm{T}_{3 \mathrm{C}}$ & 0.16 & 0.07 & 0.07 & NA & NA & NA & $\mathrm{NA}$ \\
\hline A & 0.00 & 0.00 & 0.00 & 0.00 & 0.00 & 0.00 & 0.00 \\
\hline $\mathrm{A}_{\mathrm{HY}}$ & NA & NA & NA & NA & 0.00 & NA & NA \\
\hline$S_{1}$ & 0.00 & 0.00 & 0.00 & 0.00 & 0.00 & 0.00 & 0.00 \\
\hline$S_{1 H}$ & NA & NA & NA & NA & 0.00 & NA & NA \\
\hline $\mathrm{S}_{2}$ & 0.00 & 0.00 & 0.00 & 0.00 & 0.00 & 0.00 & 0.00 \\
\hline $\mathrm{S}_{2 \mathrm{H}}$ & NA & NA & NA & NA & 0.00 & NA & NA \\
\hline$S_{3}$ & 0.00 & 0.00 & 0.00 & 0.00 & 0.00 & 0.00 & 0.00 \\
\hline $\mathrm{S}_{3 \mathrm{H}}$ & NA & NA & NA & NA & 0.00 & NA & NA \\
\hline $\mathrm{V}$ & NA & NA & NA & NA & NA & NA & NA \\
\hline $\mathbf{R}$ & NA & NA & NA & NA & NA & NA & NA \\
\hline $\mathrm{H}_{1}$ & NA & $\mathrm{NA}$ & NA & 0.06 & 0.06 & 0.06 & 0.06 \\
\hline $\mathrm{H}_{2}$ & NA & NA & NA & NA & NA & NA & NA \\
\hline $\mathrm{J}_{1}$ & $?$ & $?$ & $?$ & NA & NA & NA & NA \\
\hline $\mathrm{J}_{2}$ & NA & NA & NA & 0.02 & 0.02 & 0.02 & 0.02 \\
\hline $\mathbf{K}$ & - & - & - & - & - & - & - \\
\hline $\mathrm{E}_{1 \mathrm{~B}}$ & NA & NA & NA & 0.06 & 0.06 & 0.06 & 0.06 \\
\hline$E_{1 c}$ & NA & NA & NA & NA & 0.00 & NA & $?$ \\
\hline $\mathrm{E}_{1 \mathrm{D}}$ & NA & NA & NA & NA & 0.06 & 0.06 & 0.06 \\
\hline$E_{1 T}$ & NA & NA & NA & 0.36 & 0.36 & 0.36 & 0.36 \\
\hline $\mathrm{E}_{\mathbf{1 v}}$ & NA & NA & NA & NA & 0.36 & 0.36 & 0.36 \\
\hline$E_{2 B}$ & NÁ & NA & NA & 0.07 & 0.07 & 0.07 & 0.07 \\
\hline$E_{2 c}$ & $\mathrm{NA}$ & $\mathrm{NA}$ & NA & NA & 0.00 & $\mathrm{NA}$ & $?$ \\
\hline
\end{tabular}


Table A.3.6 (continued)

\begin{tabular}{|c|c|c|c|c|c|c|c|}
\hline Initiator & POS 1 & POS 2 & POS 3 & POS 4 & 0.07 & 0.07 & 0.07 \\
\hline$E_{2 D}$ & NA & NA & NA & NA & 0.07 & 0.07 & 0.07 \\
\hline $\mathrm{E}_{2 \mathrm{~T}}$ & NA & NA & NA & 0.04 & 0.04 & 0.04 & 0.04 \\
\hline$E_{2 V}$ & NA & NA & NA & NA & 0.04 & 0.04 & 0.04 \\
\hline $\mathrm{T}_{4 \mathrm{~A}}$ & NA & NA & NA & NA & NA & NA & NA \\
\hline $\mathrm{T}_{4 \mathrm{~B}}$ & NA & NA & NA & NA & NA & NA & NA \\
\hline $\mathrm{T}_{4 \mathrm{C}}$ & NA & NA & NA & NA & NA & NA & NA \\
\hline $\mathrm{T}_{5 \mathrm{~A}}$ & NA & NA & NA & 0.02 & 0.02 & 0.02 & 0.02 \\
\hline $\mathrm{T}_{5 \mathrm{~B}}$ & 0.02 & 0.02 & 0.02 & 0.02 & 0.02 & 0.02 & 0.02 \\
\hline $\mathrm{T}_{5 \mathrm{C}}$ & 0.02 & 0.02 & 0.02 & 0.02 & 0.02 & 0.02 & 0.02 \\
\hline $\mathrm{T}_{5 \mathrm{D}}$ & NA & NA & NA & 0.02 & 0.02 & 0.02 & 0.02 \\
\hline $\mathrm{T}_{\mathrm{AB}}$ & NA & $\mathrm{NA}$ & NA & 0.00 & 0.00 & 0.00 & 0.00 \\
\hline $\mathrm{T}_{\mathrm{DB}}$ & NA & NA & NA & 0.01 & 0.01 & 0.01 & 0.01 \\
\hline $\mathrm{T}_{\mathrm{IA}}$ & 0.18 & 0.18 & 0.18 & 0.18 & 0.18 & 0.18 & 0.18 \\
\hline $\mathrm{T}_{\text {ORV }}$ & NA & NA & NA & 0.07 & 0.07 & NA & NA \\
\hline $\mathrm{T}_{\mathrm{IOP}}$ & NA & NA. & NA & 0.00 & 0.00 & NA & NA \\
\hline $\mathrm{T}_{\mathrm{IIP}}$ & NA & $\mathrm{NA}$ & NA & 0.01 & 0.01 & NA & NA \\
\hline $\mathrm{T}_{\mathrm{IOF}}$ & NA & NA & NA & 0.02 & 0.02 & NA & NA \\
\hline $\mathrm{T}_{\mathrm{RPT}}$ & NA & NA & NA & 0.07 & 0.07 & NA & NA \\
\hline $\mathrm{T}_{\mathrm{LM}}$ & NA & NA & NA & 0.01 & 0.01 & NA & NA \\
\hline
\end{tabular}


Appendix

\section{A.4 Determination of Success Criteria and Time Windows}

For initiating events occurring during shutdown conditions, different systems or functions can potentially be used to mitigate the accident. The conditions under which a system or function are effective and their success criteria have to be determined based on thermal-hydraulic considerations. Tables A.4.1 and A.4.2 list the different systems and functions that have been identified for PWRs and BWRs respectively. Tables A.4.3 and A.4.4 list the studies that evaluate the effectiveness of these systems and functions for PWRs and BWRs respectively. It should be mentioned that for a specific plant, the plant specific design has to be taken into consideration in determining the timing and success criteria.

Decay heat is an important parameter that has to be correctly accounted for in a PRA for shutdown conditions. It affects the success criteria used and the timing of the accident scenarios. In a realistic analysis, the decay heat and accident timing have to be well defined. A way to account for decay heat was developed in Reference [3] in which a "Time Window" approach was used to determine the success criteria and timing for accidents that may occur during mid-loop operation at the Surry plant. The following is a generalization of the time window approach applied to a shutdown POS:

\section{(1) Determination of Success Criteria as a Function of Decay Heat}

The success criteria for the mitigating functions in the event tree analysis have to be determined based on the decay heat level, initial conditions of a POS, and preceding events in the accident sequences. For given initial conditions and preceding events in a sequence, the decay heat determines the success criterion for a mitigating function. Table A.4.5 is an example, taken from Reference [3], that shows how the success criteria change with decay heat for the Surry plant.

\section{(2) Definition of Time Windows after Shutdown Based on the Changing Success Criteria with Decay Heat}

The time windows are defined based on the time after shutdown when the success criteria of a system or function change with decay heat. In general, whenever the success criteria for one system or mitigating function changes, a new time window needs to be defined, and potentially, a large number of time windows could be needed. To reduce the number of time windows to a manageable number, several potential windows can be merged into a single time window. Table A.4.6 lists the four time windows that were used in Reference [3]. In this study, a total of more than ten time windows could have been used. The use of four windows (as shown in the table) is, therefore, a trade-off between the accuracy of the model and the level of effort needed to arrive at a solution. It is up to the analysts to demonstrate that the merging of the time windows gives an adequate representation without sacrificing the accuracy of the analysis. With the time windows defined, the decay heat level for each time window is better defined, and the timing of the accident scenarios can be better defined. The timing of the scenarios is an important factor that affect the performance of the operators and is an important input to the human reliability analysis.

\section{(3) Collection of Data on the Time after Shutdown When a POS Is First Reached and Duration of the POS}

The time after shutdown when a POS might start and the duration of the POS are data that have to be collected for the specific plant being analyzed. Data from other plants can potentially be use as the population data in the statistical analysis. The time when a POS is reached can be identified in the Monthly Report of Operation that each plant submits to the NRC. The duration of the POS can be identified in the shift supervisor's log books for the past outages. The POSs defined in a PRA represent a simplified model of a constantly changing plant configuration. Therefore, data on 
the duration of a POS may involve the analyst's judgment on the plant condition when reviewing the shift supervisor's log books.

\section{(4) Statistical Analysis of Time to and Duration of the POS}

The data collected in the preceding step is used in the statistical analysis to derive the probability distributions for the time when a POS is reached and the duration of the POS.

\section{(5) Determination of Distributions of Time When the Accident Initiators Occur}

The time when the accident initiators occur can be expressed as the time when the POS is reached plus the time duration of the POS multiplied by a uniform distribution between 0 and 1 . This is based on the assumption that the initiating event occurs with a constant rate within the POS. Therefore, its probability distribution can be easily determine from the distributions for the time at which the POS is reached and the duration of the POS. Some accidents may occur at the beginning of a POS, e.g., over-draining to mid-loop operation occurs at the beginning of a mid-loop POS. For these initiating events, the time when the initiating event occurs is the same as the time when the POS is reached.

\section{(6) Determination of the Conditional Probabilities that the Accident Initiating Events Occur in the Time Windows}

The conditional probability that the accident initiating event occurs in a time window, given that it occurred in the POS, is simply the probability that the accident initiating event occurs in the time window which can be evaluated using the probability distribution determined in Step 4.

\section{(7) Use of the Conditional Probabilities in Quantifying the Accident Scenarios}

The annual frequency that an initiating event occurs in a POS is equal to the frequency of the POS times the probability that the initiating event occurs given that the plant is in the POS. The frequency that an initiating event category, $\mathrm{IE}_{\mathrm{k}}$, occurs in a particular POS $j$ of a particular type of outage, $I$, can be expressed as:

$$
\text { Frequency (outage I) per year Probability }\left(\mathrm{IE}_{k} \mid\right. \text { POS j of outage I), }
$$

where

Probability $\left(\mathrm{IE}_{\mathrm{k}} \mid\right.$ POS $\mathrm{j}$ of outage $\left.\mathrm{I}\right)=$ hourly rate $\left(\mathrm{IE}_{k}\right)$ duration of $P O S \mathrm{j}$ of outage $\mathrm{I}$.

In the time window approach, the frequency that an initiating event occurs in a given time window, window $\ell$, of a particular POS $j$ of a particular type of outage type, $I$, is the above frequency multiplied by the conditional probability of the time window given that the initiating event occurred in the specified POS and outage type, i.e.,

Frequency (outage I) per year Probability $\left(\mathrm{IE}_{\mathrm{k}} \mid \mathrm{POS} \mathrm{j}\right.$ of outage $\mathrm{I}$ )

Probability (window $\ell \mid \mathrm{IE}_{\mathrm{k}}$ in POS $\mathrm{j}$ of outage $\mathrm{I}$ ) 
Appendix

Table A.4.1 Systems and Functions for PWRs

\begin{tabular}{||ll||}
\hline (1) & Residual Heat Removal System \\
(2) & Low Pressure Injection System \\
(3) & High Pressure Injection System \\
(4) & Natural Circulation / Reflux Cooling \\
(5) & Gravity Feed from RWST \\
(6) & High Pressure and Low Pressure Recirculation Systems \\
(7) & Containment Spray System \\
(8) & Steam Generator Recirculation and Transfer System \\
(9) & Spent Fuel Pool Cooling System \\
\hline
\end{tabular}

Table A.4.2 Systems and Functions for BWRs

\begin{tabular}{||ll||}
\hline (1) & Control Rod Drive Pumps \\
(2) & Feedwater System \\
(3) & Condensate System \\
(4) & Recirculation System \\
$(5)$ & Turbine Bypass Valves \\
(6) & Auxiliary Decay Heat Removal System \\
$(7)$ & Reactor Core Isolation Cooling System \\
(8) & Safety Relief Valves \\
(9) & High Pressure Core Spray System \\
(10) & Low Pressure Core Spray System \\
(11) & Low Pressure Coolant Injection System \\
(12) & Spent Fuel Cooling System \\
\hline
\end{tabular}


Table A.4.3 References to Thermal Hydraulic Analyses for PWRs

1. Audreycheck, T.S., et al.,"Loss of RHRs Cooling While the RCS is Partially Filled," WCAP - 11916, Westinghouse Electric Corporation, July 1988.

2. Naff, S.A., et al., "Thermal-Hydraulic Processes During Reduced Inventory Operation with Loss of Residual Heat Removal,” NUREG/CR-5855, Idaho National Engineering Laboratory, April 1992.

3. Wald, L.W., et al., "Consequence of the Loss of Residual Heat Removal Systems in Pressurized Water Reactors," NUREG/CR-5820, Idaho National Engineering Laboratory, May 1992.

4. "Loss of Residual Heat Removal System," Diablo Canyon, Unit 2, April 10, 1987, NUREG-1269, U. S. NRC, June 1987.

5. "Loss of Vital AC Power and the Residual Heat Removal System During Mid-Loop Operations at Vogtle Unit 1 on March 20, 1990," NUREG-1410, U.S. NRC, June 1990.

6. Chu, T.L., et. al., "Evaluation of Potential Severe Accidents During Low Power and Shutdown Operations at Surry Unit 1, Analysis of Core Damage Frequency from Internal Events During Mid-Loop Operations," Brookhaven National Laboratory, NUREG/CR-6144, Volume 2, Chapter 5, June 1994. 
Appendix

Table A.4.4 Thermal Hydraulic Analyses Performed in Reference [4] for Grand Gulf

(1) For different decay heat level, the following were determined:

- injection flow needed to remove decay heat without steaming

- injection to remove decay heat with steaming

- time to boiling of vessel water

- time to top of fuel due to boil off

- time to suppression pool over heat

(2) Capacity of a SRV to relieve steam at different system pressure

(3) Number of SRVs needed to relieve water in support of ECCS injection

(4) For different initial suppression pool levels, decay heat levels, initiating events and modes of ECCS injection, determine whether or not suppression pool makeup would be needed

(5) Determine time when containment failure pressure is reached due to heating of flooded containment with no heat removal

(6) Determine time to boil off of suppression pool inventory to where ECCS is lost.

(7) Estimate the time available to restore makeup if makeup is lost and letdown is isolated, before recirculation from the core to the down comer is lost. 
Table A.4.5 Success Criteria for Mitigating Features Used in Reference [3]

\begin{tabular}{|c|c|c|c|}
\hline \multirow[t]{2}{*}{ Feature } & \multirow[t]{2}{*}{ Time Window } & \multicolumn{2}{|c|}{ Success Criteria } \\
\hline & & Short Term & Long Term \\
\hline \multirow[t]{3}{*}{ Reflux Cooling } & $<75$ hours & $3 \mathrm{SGs}$ & AFW to $3 \mathrm{SGs}$ \\
\hline & $\begin{array}{l}>=75 \text { hours and } \\
<475 \text { hours }\end{array}$ & 2 SGs & AFW to 2 SGs \\
\hline & $>=475$ hours & $1 \mathrm{SG}$ & AFW to $1 \mathrm{SG}$ \\
\hline \multirow[t]{5}{*}{ Feed-and- Spill } & $<107$ hour & \multicolumn{2}{|c|}{ 1LHSI * (SV removed + 2 PORV) } \\
\hline & $>107$ hours & \multicolumn{2}{|c|}{ lLHSI * (SV removed + 1-PORV) } \\
\hline & $<129$ hours & \multicolumn{2}{|c|}{$2 \mathrm{HHSI} *(\mathrm{SV}$ removed +2 PORV $)$} \\
\hline & $\begin{array}{l}>129 \text { and } \\
<138 \text { hours }\end{array}$ & \multicolumn{2}{|c|}{$1 \mathrm{HHSI} *(\mathrm{SV}$ removed +2 PORV $)$} \\
\hline & $>=138$ hours & \multicolumn{2}{|c|}{$1 \mathrm{HHSI} *(\mathrm{SV}$ removed $+1 \mathrm{PORV})$} \\
\hline \multirow[t]{4}{*}{ Gravity Feed } & $<70$ hours & \multicolumn{2}{|c|}{ at least $1 \mathrm{SV}$ removed, less than 1 hour of subcooling } \\
\hline & $\begin{array}{l}>70 \text { hours and } \\
<150 \text { hours }\end{array}$ & \multicolumn{2}{|c|}{ at least $1 \mathrm{SV}$ removed, 2 hours of subcooling } \\
\hline & $\begin{array}{l}>150 \text { hours and } \\
\text { less than } 768 \text { hours }\end{array}$ & \multicolumn{2}{|c|}{ at least $1 \mathrm{SV}$ removed, 3 hours of subcooling } \\
\hline & $>=768$ hours & \multicolumn{2}{|c|}{ at least $1 \mathrm{SV}$ removed, sufficient for 24 hours } \\
\hline \multirow[t]{3}{*}{ Recirculation } & $<=3$ days & \multicolumn{2}{|l|}{ needed } \\
\hline & $\begin{array}{l}>3 \text { days and } \\
<=10 \text { days }\end{array}$ & \multicolumn{2}{|c|}{ not needed if RWSTs are cross tied, otherwise needed } \\
\hline & $>10$ days & \multicolumn{2}{|l|}{ not needed } \\
\hline \multirow{3}{*}{$\begin{array}{l}\text { Spray } \\
\text { Recirculation }\end{array}$} & $<=3$ days & \multicolumn{2}{|c|}{ needed to prevent recirculation failure } \\
\hline & $\begin{array}{l}>3 \text { days and } \\
<=10 \text { days }\end{array}$ & \multicolumn{2}{|c|}{$\begin{array}{l}\text { not needed if RWSTs are cross tied, otherwise needed to prevent } \\
\text { recirculation failure }\end{array}$} \\
\hline & $>10$ days & \multicolumn{2}{|l|}{ not needed } \\
\hline
\end{tabular}


Table A.4.6 Definition and Characterization of Time Windows Used in Reference [3]

\begin{tabular}{|c|c|c|c|c|}
\hline & WINDOW 1 & WINDOW 2 & WINDOW 3 & WINDOW 4 \\
\hline Definition & $<=75$ hours & $\begin{array}{l}>75 \text { hours and } \\
<=240 \text { hours }\end{array}$ & $\begin{array}{c}>240 \text { hours and } \\
<=32 \text { days }\end{array}$ & $>32$ days \\
\hline $\begin{array}{l}\text { Representative } \\
\text { Decay Heat }\end{array}$ & $13.23 \mathrm{MW}$ (2days) ${ }^{*}$ & $10 \mathrm{MW}$ (5 days) & $7 \mathrm{MW}$ (12 days) & $5 \mathrm{MW}(32$ days $)$ \\
\hline \multicolumn{5}{|l|}{ Success Criteria } \\
\hline Reflux Cooling & 3 SGs & 2 SG & $2 \mathrm{SG}$ & $1 \mathrm{SG}$ \\
\hline \multicolumn{5}{|l|}{ Feed and Bleed } \\
\hline LHSI & $\begin{array}{c}\text { 1LHSI*(SV removed } \\
+2 \text { PORV) }\end{array}$ & $\begin{array}{c}\text { 1LHSI*(SV removed } \\
+2 \text { PORV) }\end{array}$ & $\begin{array}{c}\text { 1LHSI *(SV removed } \\
+1 \text { PORV })\end{array}$ & $\begin{array}{c}\text { 1LHSI *(SV removed } \\
+1 \text { PORV })\end{array}$ \\
\hline HHSI & $\begin{array}{c}\text { 1HHSI*(SV removed } \\
+1 \text { PORV })\end{array}$ & $\begin{array}{c}\text { 1HHSI*(SV removed } \\
+1 \text { PORV) }\end{array}$ & $\begin{array}{c}\text { 1HHSI*(SV removed } \\
+1 \text { PORV) }\end{array}$ & $\begin{array}{c}\text { 1HHSI*(SV removed } \\
+1 \text { PORV) }\end{array}$ \\
\hline Gravity Feed & $\begin{array}{l}1 \text { SV removed * LHSI } \\
\text { flow path provides } \\
4.3 \text { hours for operator } \\
\text { actions (with less than } \\
2 \text { hours of subcooling) }\end{array}$ & $\begin{array}{l}1 \mathrm{SV} \text { removed } * \text { LHSI } \\
\text { flow path provides } \\
6.5 \text { hours for operator } \\
\text { actions (with } 2 \text { hours } \\
\text { of subcooling) }\end{array}$ & $\begin{array}{l}\text { 1 SV removed * LHSI } \\
\text { flow path provides } \\
12 \text { hours for operator } \\
\text { actions (with } 2 \text { hours } \\
\text { of subcooling) }\end{array}$ & $\begin{array}{l}1 \text { SV removed * LHSI } \\
\text { flow path provides } \\
\text { sufficient cooling for } \\
24 \text { hours (with more } \\
\text { than } 3 \text { hours of } \\
\text { subcooling) }\end{array}$ \\
\hline \multirow[t]{2}{*}{ Recirculation } & \multirow{2}{*}{$\begin{array}{c}\text { needed(HPR + } \\
\text { LPF\&Steam } \\
\text { + LPF\&Spill) }\end{array}$} & 1 RWST, needed & \multirow[t]{2}{*}{ not needed } & \multirow[t]{2}{*}{ not needed } \\
\hline & & 2 RWST, not needed & & \\
\hline \multirow{2}{*}{$\begin{array}{l}\text { Recirculation } \\
\text { Spray }\end{array}$} & \multirow[t]{2}{*}{ needed } & 1 RWST, NEEDED & \multirow[t]{2}{*}{ not needed } & \multirow[t]{2}{*}{ not needed } \\
\hline & & 2 RWST, not needed & & \\
\hline \multicolumn{5}{|c|}{ Probability that IE Occurs in the Window } \\
\hline D6 & $\begin{array}{l}0.117 \\
(0.31)^{*}\end{array}$ & $\begin{array}{c}0.436 \\
(0.454)\end{array}$ & $\begin{array}{r}0.375 \\
(0.21)\end{array}$ & $\begin{array}{r}7.20 \mathrm{E}-02 \\
(2.6 \mathrm{E}-02)\end{array}$ \\
\hline R6 & $\begin{array}{c}1.7 \mathrm{E}-02 \\
(5.82 \mathrm{E}-02)\end{array}$ & $\begin{array}{l}0.543 \\
(0.7)\end{array}$ & $\begin{array}{c}0.41 \\
(0.24)\end{array}$ & $\begin{array}{l}3.4 \mathrm{E}-02 \\
(1.48 \mathrm{E}-03)\end{array}$ \\
\hline R10 & 0.0 & $0: 0$ & $\begin{array}{c}0.016 \\
(2.2 \mathrm{E}-02)\end{array}$ & $\begin{array}{c}9.84 \mathrm{E}-01 \\
(0.98)\end{array}$ \\
\hline
\end{tabular}


Table A.4.6 (continued)

\begin{tabular}{|c|c|c|c|c|}
\hline & WINDOW 1 & WINDOW 2 & WINDOW 3 & WINDOW 4 \\
\hline Decay Heat & 13.23 MW( 2 days) & $10 \mathrm{MW}(5$ days $)$ & $7 \mathrm{MW}(12$ days $)$ & $5 \mathrm{MW}(32$ days) \\
\hline Time to Boiling & $15 \mathrm{~min}$. & $20 \mathrm{~min}$. & $27 \mathrm{~min}$. & $37 \mathrm{~min}$ \\
\hline $\begin{array}{l}\text { Time to Tygon } \\
\text { Tube Rupture( } 40 \\
\text { psia) }\end{array}$ & $23 \mathrm{~min}$. & $31 \mathrm{~min}$. & $43 \mathrm{~min}$. & $59 \mathrm{~min}$. \\
\hline $\begin{array}{l}\text { Time to PRT } \\
\text { Rupture(100 psig) }\end{array}$ & $51 \mathrm{~min}$. & $63 \mathrm{~min}$. & $78 \mathrm{~min}$. & $96 \mathrm{~min}$. \\
\hline Time to $165 \mathrm{psia}$ & $\begin{array}{l}41 \mathrm{~min} \text {. with } 2 \text { PORV } \\
43 \mathrm{~min} \text {. with } 1 \text { PORV }\end{array}$ & $\begin{array}{l}63 \mathrm{~min} \text {. with } 2 \text { PORV } \\
60 \mathrm{~min} \text {. with } 1 \text { PORV }\end{array}$ & $\begin{array}{l}227 \text { min. with } 2 \text { PORV } \\
89 \text { min. with } 1 \text { PORV }\end{array}$ & $\begin{array}{c}352 \text { min. with } \\
2 \text { PORV } \\
147 \text { min. with } 1 \\
\text { PORV }\end{array}$ \\
\hline Time to $615 \mathrm{psig}$ & $\begin{array}{l}145 \text { min. with } 1 \\
\text { PORV - with two }\end{array}$ & - & - & - \\
\hline $\begin{array}{l}\text { Time to RWST } \\
\text { Depletion }\end{array}$ & $10 \mathrm{hrs}$ & $13.5 \mathrm{hrs}$ & $18.7 \mathrm{hrs}$ & $38.6 \mathrm{hrs}$ \\
\hline $\begin{array}{l}\text { Time to AFW } \\
\text { Initiation(with } \\
25 \% \mathrm{SG} \\
\text { inventory } \\
\text { remaining) }\end{array}$ & $743 \mathrm{~min}$. & $669 \mathrm{~min}$. & $925 \mathrm{~min}$. & $628 \mathrm{~min}$. \\
\hline $\begin{array}{l}\text { Time to Core } \\
\text { Uncovery }\end{array}$ & $120 \mathrm{~min}$. & $157 \mathrm{~min}$. & $209 \mathrm{~min}$. & $273 \mathrm{~min}$. \\
\hline $\begin{array}{l}\text { Time to Core } \\
\text { Damage }\end{array}$ & $219 \mathrm{~min}$ & $297 \mathrm{~min}$. & $411 \mathrm{~min}$. & $557 \mathrm{~min}$. \\
\hline
\end{tabular}

Vol. 1 
Appendix

\section{A.5 System Analysis}

System configurations during shutdown conditions can be identified by reviewing system training manuals, operating procedures used during shutdown conditions, and shift supervisor's log books. Typically, 2 or 3 different configurations may be needed to model a system. For example, for the residual heat removal system, one configuration for power operation and one for shutdown conditions would be needed. Discussions with systems engineers would be useful to better define the system configuration. Typically, the shutdown configuration of a system may differ from that of power operations in the following way:

- Valves may be in a different normal position than that of power operations.

- Automatic signals may not exist during shutdown, or may not operate in the way that supports the functions needed to mitigate an accident.

- A system or component may be in a condition that makes it impossible to operate. For example, the turbine driven auxiliary feedwater pump does not have the steam needed to run during a cold shutdown.

- Test or maintenance may make a system or component unavailable for a long time. For example, the steam generators at the Surry plant are isolated in a refueling outage for a long time.

The following are typical changes needed to convert the system fault trees developed for power operations into those suitable for shutdown conditions:

- Different failure modes of a valve may be applicable due to the different normal position.

- If the automatic signal for actuating a component does not exist during shutdown, then failure of the signal should not be a cause of failure of the component. If the component requires operator action for its actuation, the human error event has to be modeled in the fault trees.

- The physical condition of the plant may prohibit the operation of some items of equipment. The equipment should be identified and not included in the system analysis.

- Maintenance unavailabilities of equipment have to be estimated and modeled in the fault trees. In principle, they could vary from one POS to another.

\section{A.6 Development of Event Trees and Accident Scenarios}

The development of event trees and accident scenarios requires a good understanding of the plant response to the initiating event. For accidents that happen during LP\&S conditions, there may not be any emergency procedures that instruct the operator as to an appropriate course of action. Whatever procedures and training are available have to be used. This includes procedures developed for accidents during power operations which may have relevant steps that are applicable to shutdown accidents. Ultimately, the scenarios developed have to be discussed with plant personnel such as operators and system engineers, to ensure they are realistic. 
The event trees that delineate the accident scenarios can be developed in the same way event trees are developed for a PRA for power operation. The following is a summary of the approaches used in existing studies ${ }^{[3-6]}$ :

- Surry LP\&S Study ${ }^{[3]}$ - In this study, the event trees were developed by using the mitigating functions defined in the abnormal procedure for loss of RHR as top events. The event trees are small and the fault trees for the top events include hardware failures of systems and human error events.

- Grand Gulf Study ${ }^{[4]}$ - In this study the event trees were developed in stages. First, generic functional event trees were developed, followed by the generic system-level event trees, and last, the initiating event specific systemlevel event trees were developed. The latter include many levels of transfers from one event tree to the other, and became difficult to solve. The advantage of such approach is that the sequences are more explicitly defined. The disadvantage is that solving the event trees is very time consuming.

- Zion ${ }^{[5]}$ and Seabrook ${ }^{[6]}$ Studies - These studies used the same type of event trees as the Surry LP\&S studyexoept that the large event tree approach was used instead of the large fault tree approach.

\section{A.7 Human Reliability Analysis}

Human reliability analysis (HRA) is a very important part of a PRA for LP\&S conditions. The human reliability analysis in a PRA consists of the following key tasks:

\section{- Identification of operator actions/errors}

Different types of human errors can be identified, and defined based on their impact on the plant. For example, diagnosis errors and action errors, errors committed before the initiating events and errors committed after the initiating events.

\section{- Inclusion of human error events in the logic model for accident scenario quantification}

Depending on the types of human errors, they can be included in different parts of a PRA model. Typically, preinitiating event errors are included in system fault trees. Post-initiating events can be included in system fault trees or as top events of event trees. In Reference [3], diagnosis errors are consistently applied to all core damage sequences, and failure to diagnose is assumed to caused failure of all mitigating functions. Action errors can be included in the logic model for the hardware that they affect.

\section{- Quantification of human error probabilities}

For each clearly defined human error, different methods can be used to estimate the human error probability. Reference [3] used the success likelihood index methodology ${ }^{[13]}$, and Reference [4] used the Accident Sequence Evaluation Program Human Reliability Analysis Procedure (ASEP HRAP). ${ }^{[14]}$ 
Appendix

\subsection{Presentation of Results}

For each of the tasks of a LP\&S PRA, the following documentation should be provided.

- Outage Types and Plant Operational States

The definition of outage types should be provided such that all possible outages are included. The boundaries between POSs should be clearly defined. Descriptions of major activities in each of the POS should be provided. A table showing the frequency and duration of the POSs should also include the source of data that was used.

- Initiating Event Analysis

A table of initiating events should be provided for each POS, providing quantitative estimates of the IE frequencies. Detailed discussions should be provided on the effects each IE has on the plant and the automatic response of the plant subsequent to the IE.

- $\quad$ Success Criteria

For each POS, a table of different methods of providing inventory makeup, decay heat removal, and reactivity control should be provided. The way in which the train level success criteria change with the decay heat should also be described. Supporting thermal-hydraulic analyses that determine the success criteria need to be provided. For each mitigating function, descriptions on the operator actions and the time needed to activate the function are needed.

- System Analysis

For each system that can be used to mitigate an accident, a description of the system configuration during each POS, including the conditions of the support systems, and actuation signals is needed. For each system included in the analysis, the physical condition needed for system operation should be described. It is also important to verify that the conditions are satisfied for those scenarios in which the system is operational. If operator actions are needed, they should be described and the amount of time estimated.

\section{- Event Tree Analysis and Accident Scenario Development}

The dominant scenarios that contribute to at least $90 \%$ of the total core damage frequency (including the basic events and their probabilities used in the quantification) should be described.

\section{- Human Reliability Analysis}

Human error events that appear in the dominant core damage scenarios, including the methods of the HEP quantification, should be described.

- Results

The results should be presented in terms of core damage frequency and conditional core damage frequency for each time window in each POS. A comparison of the conditional core damage frequencies among the POSs with $\mathrm{CDF}$ for power operation should be provided. The reasons for any differences in the results should be explained. 
Appendix

\section{A.9 References}

1. Bari, R. A. et al.., "Probabilistic Safety Analysis Procedures Guide", Brookhaven National Laboratory, NUREG/CR-2815, August 1985.

2. "PRA Procedures Guide, A Guide to the Performance of Probabilistic Risk Assessments for Nuclear Power Plants," NUREG/CR-2300, Volumes 1 and 2, January 1983.

3. Chu, T.-L. et. al., "Evaluation of Potential Severe Accidents during Low Power and Shutdown Operations at Surry Unit-1, Analysis of Core Damage Frequency from Internal Events During Mid-Loop Operations", Brookhaven National Laboratory, NUREG/CR-6144, Volume 2, June 1994.

4. Whitehead, D. et. al., "Evaluation of Potential Severe Accidents during Low Power and Shutdown Operations Grand Gulf, Analysis of Core Damage Frequency from Internal Events during Plant Operational State 5 of a Refueling Outage", Sandia National Laboratories, NUREG/CR-6143, Volume 2, June 1994.

5. Kiper, K. L. et. al., "Seabrook Probabilistic Safety Study, Shutdown (modes 4,5, and 6)", New Hampshire Yankee, Volumes 1 and 2, May 1988.

6. Bley, D. C. et al., "Zion Nuclear Plant Residual Heat Removal PRA," EPRI/NSAC Report NSAC-84, prepared by Pickard, Lowe, and Garrick, Inc., July 1983.

7. "A Probabilistic Safety Assessment of the Standard French 900 MWe Pressurized Water Reactor", Institute de Protection et de Surete Nucleaire, EPS 900, Main Report, April 1990.

8. Diamond, D. J. et. al., "Probability and Consequences of Rapid Boron Dilution in a PWR, a Scoping Study", Brookhaven National Laboratory, NUREG/CR-5819, June 1992.

9. Audreycheck, T. S. et. al.,"Loss of RHRs Cooling while the RCS is partially filled," WCAP - 11916, Westinghouse Electric Corporation, July 1988.

10. "Loss of Decay Heat Removal”, Generic Letter 88-17, US NRC, October 17,1988.

11. Diamond, D. J., C. J. Hsu, R. Fitzpatrick, "Reactivity Accidents, A Reassessment of the Design-Basis Events", Brookhaven National Laboratory, NUREG/CR-5368, January 1990.

12. Sailor, V. L. et al., "Severe Accidents in Spent Fuel Pools in Support of Generic Safety Issue 82," NUREG/CR4982, BNL-NUREG-52093, July 1987.

13. Chien, S. H., A. A. Dykes, J. W. Stetkar, and D. C. Bley, "Quantification of Human Error Rates Using a SLIM-Based Approach," Proceedings of the 1988 IEEE Fourth Conference on Human Factors and Power Plants, Monterey, California, June 5-9, 1988.

14. Swain, A. D., "Accident Sequence Evaluation Program Human Reliability Analysis Procedure," NUREG/CR-4772, February, 1987.

Vol. 1 


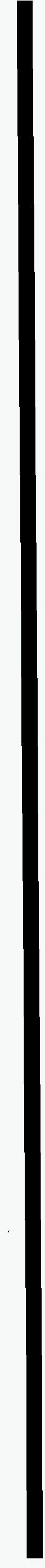




\section{Distribution List}

Kiyohanu Abe

Dept. of Reactor Safety Research Nuclear Safety Research Center Tokai Research Establishment

JAERI

Tokai-mura, Naga-gun

Ibaraki-ken,

JAPAN

Sarbes Aicharya

Department of Energy

NS-1/FORS

Washington, DC 20585

Dr. Ulvi Adalioglu

Cekmece Nukleer Arastraima ve

Egitim Merekezi

P.K. 1

Havaalani/ISTANBUL

TURKEY

Dr. Eng. Kiyoto Aizawa

Senior Engineer

Reactor Eng. Dev. Department

PNC

9-13, Chome, Akasaka

Minato-K, Tokyo

JAPAN

Harry Alter

Manager Applied Tech

Nuclear Systems Tech

NE-46

US DOE

Washington, DC 20585
R.M. Andrews

Nuclear Installations Insp.

St. Peters House

Balliol Raod, Bootle

Merseyside L20 312

UNITED KINGDOM

George Apostolakis

Massachusetts Institute of

Technology

77 Massachusetts Avenue

Cambridge, MA 02139

Director of Reactor Engineering

Argonne National Laboratory

9700 S Cass Ave

Bldg 208

Argonne, IL 60439

Ephraim Asculai

Division of Nuclear Safety

Wagramestrasse, 5

P.O. Box 100

A-1400 Wien

AUSTRIA

Vladimar Asmoloy

Head, Nuclear Safety Department

I. V. Kurchatov Institute

of Atomic Enegry

Moscow, 123181

RUSSIA 
J. de Assuncao

Cabinete de Proteçăo è

Seguranca Nuclear

Ministerio da Indusstria

Ave. de Republica 45-6

1000 Lisbon

PORTUGAL

\section{H.P. Balfanz, Head}

Institute of Probabilistic

Safety Analysis

TUV Nord

Grosse Bahnstrasse 31

D-22525 Hamburg 54

GERMANY

Pat Baranowsky

USNRC-AEOD/RRAB

MS: T-4A9

Librarian

Technical Information Section

Battelle Pacific Northwest Lab

P. O. Box 999

Richland, WA 99352

Andrea Besi

Institute for Systems Engineering

and Informatics

CEC Joint Research Centre

CP N 1

1-21020 Ispra (Varese)

ITALY

Vicki Bier

Dept. of Industrial Engineering

University of Wisconsin-Madison

1513 University Avenue, Room 389

Wisconsin, WI 53706
Scott Bigelow

S-CUBED

2501 Yale SE, Suite 300

Albuquerque, NM 87106

Prof. Dr. Dr.-Ing. E. H. Adolf

Birkhofer

Gesellschaft für Anlagen und Reaktorsicherheit (GRS) mbH

Forschungsgelände

D-8046 Garching

Federal Republic of Germany

David Black

American Electric Power

1 Riverside Plaza

Columbus, OH 43215

Harold Blackman

Idaho National Engineering Lab.

LMIT MS: 3850

P.O. Box 1625

Idaho Falls, ID 83415-3850

Dennis Bley

Buttonwood Consulting

17291 Buttonwood St.

Fountain Valley, CA 92708

Roger Blond

Booz-Allen \& Hamilton

4330 East West Highway

Bethesda, MD 20814

M. P. Bohn

Division 6449

Sandia National Laboratories

Albuquerque, NM 87185 
Dr. Mario Bonaca

Manager, Reactor Engineering

Northeast Utilities

P.O. Box 270

Hartford, Conn. 06141

Robert B. Borsum

Nuclear Power Division

B \& W Nuclear Tech

1700 Rockville Pike

Suite 525

Rockville, MD 20852

Stephen Boult

Electrowatt Engineering Services

(UK) Ltd.

Grandford House

16 Carfax, Horsham

West. Sussex RH12 IUP

ENGLAND

Gary Boyd

Safety \& Reliability Optimization

Services

9724 Kingston Pike, Suite 102

Knoxville, TN 37922

David M. Brown

Paul C. Rizzo Associates, Inc.

300 Oxford Drive

Monroeville, PA 15146-2347

Tom D. Brown

Sandia National Laboratories

Dept. 6413

P.O. Box 5800

Albuquerque; NM 87185

Robert J. Budnitz

Future Resources Associates, Inc. 2039 Shattuck Avenue, Suite 402

Berkeley, CA 94704
Arthur Buslik

USNRC-RES/PRAB

MS: T-10E50

Edward Butcher

USNRC-NRR/SPSB

MS: 0-10E4

Technical Library

B\&W Nuclear Service Co

P. O. Box 10935

Lynchburg, VA 24506

Stefaan Caeymaex

Safety \& Systems Section

Nuclear Generation Dept.

TRACTEBEL

Avenue Ariane 7

B-1200 Bruxelles

BELGIUM

Leonard Callan, Administrator

U.S. Nuclear Regulatory Commission

Harris Tower and Pavilion

611 Ryan Plaza Drive, Suite 400

Arlington, TX 76011-8064

J. Calvo

Division of PSA \& Human Factors

Consejo de Seguridad Nuclear

Calle Justo Dorado, 11

28040 Madrid

SPAIN

A. L. Camp

Division 6412

MS: 0748

Sandia National Laboratories

Albuquerque, NM 87185-0748

Dist-3 
John Forbes Campbel

HM Superintending Inspector

Health \& Safety Executive

St. Peter's House

Balliol Road

Bootle L20 $31 Z$

UNITED KINGDOM

Leonel Canelas

New University of Lisbon

Quinta de Torre

2825 Monte de Caparica

PORTUGAL

Harold Careway

General Electric Co., M/C 754

175 Curtner Ave.

San Jose, CA 95129

D. D. Carlson

Division 6411

Sandia National Laboratories

Albuquerque, NM 87185

Jose E. De Carlos

CSN International Coordinator

Consejo de Seguridad Nuclear

Calle Justo Dorado 11

28040 Madrid

SPAIN

Annick Carnino

International Atomic Energy Agency

Wagramerstrasse 5, P.O. Box 100

A-1400 Vienna

AUSTRIA
S. Chakraborty

Swiss Federal Nuclear Safety

Inspectorate

Hauptabteilung für die Sicherheit

der Kernanlagen

CH-5232 Villigen-HSK

SWITZERLAND

Erulappa Chelliah

USNRC-RES/PRAB

MS: T-10E50

Mike Cheok

NUS

910 Clopper Road

Gaithersburg, MD 20878

Nilesh Chokshi

USNRC-RES/SSEB

MS: T-10LI

Peter Cooper

SRD/AEA Technology

Wigshaw Lane

Culcheth

Cheshire WA3 4NE

England

Susan E. Coopèr

Science Applications Int'l. Corp.

11251 Roger Bacon Drive

Reston, VA 22090

Michael Corradini

University of Wisconsin

1500 Johnson Drive

Madison, WI 53706 
E.R. Corran

ANSTO Reasearch Establishment Lucas Heights Reserch Labs.

Private Mail Bag 1

Manai, NSW 2234

AUSTRALIA

Massimo Cozzone

A.N.P.A.

Via V. Brancati, 48

I-00144 Rome

ITALY

George Crane

1570 E. Hobble Creek Dr.

Springville, Utah 84663

Mark Cunningham

USNRC-RES/PRAB

MS: T-10E50

S. Daggupaty

Environment Canada

4905 Dufferin Street

Downsview

Ontario, M3H ST4

CANADA

Louise Dahlerup

Inspectorate of Nuclear Inst.

Danish Civil Defense \&

Emergency Planning Agency

16, Datavej

DK-3460 Birkerod

DENMARK

John Darby

SEA, Inc.

6100 Uptown Blvd. NE

Albuquerque, NM 87110
Gerald Davidson

Fauske and Associates, Inc.

16 W 070 West 83rd Street

Burr Ridge, IL 60521

Peter R. Davis

PRD Consulting

P.O. Box 2046

Sheridan, WY 82801

P. De Gelder

Secretary, BELGIAN NUCLEAR

SOCIETY (BNS)

A V Nuclear

Avenue du Roi 157

B-1060 Brussels

BELGIUM

Lennart Devell

Studsvik Nuclear

Studsvik Energiteknik AB

S-611 82 Nykoping

SWEDEN

J. Devooght

Service de la Metrologie Nucl

University Libre de Bruxelles

Faculte des Sciees Appliqu.

50 Avenue F-D Roosevelt

Bruxelles 5

BELGIUM

G. Diederick

Commonwealth Edison Co.

LaSalle County Station

RR1, Box 220

2601 North 21st Rd.

Marsielles, IL 61341

Dist-5 
Chuck Dobbe

Idaho National Engineering Lab.

EG\&G MS: 3840

P.O. Box 1625

Idaho Falls, ID 83415

\section{Dang}

Paul Scherrer Institute

Wuerenlingen

Villigen CH-5231

Switzerland

Mary Drouin

USNRC-RES/PRAB

MS: T-10E50

Duke Power Co. (2) Attn: Duncan Brewer

Steve Deskevich

422 South Church Street

Charlotte, NC 28242

Bill Eakin

Northeast Utilities

Box 270

Hartford, CT 06141

Stewart D. Ebneter

USNRC

101 Marietta St., Suite 2900

Atlanta, GA 30323-0199

Adel A. El-Bassioni USNRC-NRR/PRAB

MS: O-10E4
ENEA/DISP (2)

Attn: Alvaro Valeri

Alfredo Bottino

Via Vitaliano Brancati, 48

00144 Roma EUR

ITALY

Walter P. Engel

PRAG MGR Analysis \& Reg Matter

NE-60

CRYCITY

US DOE

Washington, DC 20585

John Flack

USNRC-RES/PRAB

MS: T-10E50

Karl Fleming

Pickard, Lowe \& Garrick

2260 University Drive

Newport Beach, CA 92660

Terry Foppe

Safety Analysis Engineering

Rocky Flats Plant

Energy Systems Group

Rockwell International Corp

P.O. Box 464

Golden, CO 80401

R H. Gauger

Manager-Reliability Engr

A/E Div

Holmes \& Narver Inc.

R Roanne Circle

Irvine, CA 92714 
Robert Gobel

Clark University

Center for Technology, Environment and Development

950 Main St.

Worcester, MA 01610-1477

Paul Govaerts

Studiecentrum voor Kernenergie

(SCK/CEN)

Boeretang, 200

B-2400 Mol

BELGIUM

Mr. Gubler

International Atomic Energy Agency

NENS/SAD B0842

Wagramerstrasse 5, P.O. Box 100

A-1140 Vienna

AUSTRIA

Paul M. Haas, President

Concord Associates, Inc.

725 Pellissippi Parkway

Suite 101, Box 6

Knoxville, TN 37933

F. T. Harper

Division 6413

MS: 0748

Sandia National Laboratories

Albuquerque, NM 87185-0748

Dr. U. Hauptmanns

Gesellschaft Für Anlagen und

Reaktorsicherheit (GRS) mgH

Schwertnergasse 1

D-5000 Köln 1

GERMANY
Sharif Heger

UNM Chemical and Nuclear

Engineering Department

Farris Engineering, Room 209

Albuquerque, NM 87131

Jon C. Helton

Dept. of Mathematics

Arizona State University

Tempa, AZ 85287

Dr. P. M. Herttrich

Gesellschaft für Anlagen und Reaktorsicherheit

(GRS) $\mathrm{mbH}$

Schwertnergasse 1

5000 Köln 1

GERMANY

Dr. D.J. Higson

Radiological Safety Bureau

Australian Nuclear Science \&

Technology Organisation

P.O. Box 153

Roseberry, NSW 2018

AUSTRALIA

Dr. Mitsumasa Hirano

Deputy General Manager

Institute of Nuclear Safety

NUPEC

3-6-2, Toranomon, Minato-ku

Tokyo 108

JAPAN

Dr. S. Hirschberg

Paul Scherrer Institute

Vurenlingen and Villigen

CH-5232 Villigen PSI

SWITZERLAND 
Steven Hodge

Oak Ridge National Laboratories

P. O. Box Y

Oak Ridge, TN 37831

Gary Holahan

USNRC-NRR/DSSA

MS: O-8E2

N.J. Holloway

A72.1

Atomic Weapons Establishment

Ademaston

Reading RG7 4PR

UNITED KINGDOM

Brian Holmes

AEA Technology

Risley

Warrington WA3 AT

England

Griff Holmes

Westinghouse Electric Co.

Energy Center East

Bldg. 371

P.O. Box 355

Pittsburgh, PA 15230

William Hopkins

Bechtel Power Corporation

15740 Shady Grove Road

Gaithersburg, MD 20877
Y. M. Hou

PLG Inc.

Suite 400

4590 Mac Arthur Boulevard

Newport Beach, CA 92660

Der-Yu Hsia

Institute of Nuclear Energy Research

Lung-Tan 325

TAIWAN

Alejandro Huerta-Bahena

National Commission on Nuclear

Safety and Safeguards (CNSNS)

Insurgentes Sur N. 1776

C. P. 04230 Mexico, D. F.

MEXICO

Peter Humphreys

US Atomic Energy Authority

Wigshaw Lane, Culcheth

Warrington, Cheshire

UNITED KINGDOM, WA3 4NE

W. Huntington

Commonwealth Edison Co.

LaSalle County Station

RRl, Box 220

2601 North 21st Rd.

Marsielles, IL 61341

J.S. Hyslop

USNRC-RES/PRAB

MS: T-10E50

Idaho National Engineering Lab. (2)

Attn: Doug Brownson

Darrel Knudson

EG\&G MS: 3840

P.O. Box 1625

Idaho Falls, ID 83415 
Idaho National Engineering Lab. (2)

Attn: Art Rood

Mike Abbott

EG\&GMS: 2110

P.O. Box 1625

Idaho Falls, ID 83415

D. Ilberg

Soreq National Research Center

Yavne 70600

Israel

Hanspeter Isaak

Abteilung Strahlenschutz

Hauptabteilung für die Sicherheit

der Kernanlagen (HSK)

CH-5303 Wurenlingen

SWITZERLAND

Brian Ives

UNC Nuclear Industries

P. O. Box 490

Richland, WA 99352

Kamiar Jamili

DP-62/FTN

Department of Energy

Washington, D.C. 20585

D. Johnson

PLG Inc.

Suite 400

4590 Mac Arthur Boulevard

Newport Beach, CA 92660

Robert Jones

USNRC-NRR/DSSA/SRXB

MS: O-8E21
Edward Jordan

USNRC-AEOD/DO

MS: T-4D18

Dr. H. Kalfsbeek

$\mathrm{DG} / \mathrm{XII} / \mathrm{D} / 1$

Commission of the European Communities

Rue de la Loi, 200

B-1049 Brussels

BELGIUM

Yoshio Kano

General Mngr. \& Sr. Engineer

Systems Analysis Section

$\mathrm{O}$-arai Engineer. Centr, PNC

Higashi-Ibaraki-gun

Ibaraki-Ken, 133-13

JAPAN

William Kastenberg

UCLA

Boelter Hall, Room 5532

Los Angeles, CA 90024

Barry Kaufer

OECD/NEA

"Le Seine St. Germain" 12

Boulevard des Iles

92130 Issy-les-Moulineaux

FRANCE

Paul Kayser

Division de la Radioprotection

Avenue des Archiducs, 1

L-1135 Luxembourg-Belair

LUXEMBOURG

Ken Keith

TVA

W 20 D 201

400 West Surmnit Hill

Knoxville, TN 37092

Dist-9 
G. Neale Kelly

Commission of the European

Communities

Joint Research Centre

Rue de la Loi 200

B-1049 Brussels

BELGIUM

John Kelly

Sandia National Laboratories

P. O. Box 5800

MS 0742

Albuquerque, NM 87185

Knolls Atomic Power Laboratory (2)

Attn: Ken McDonough

Dominic Sciaudone

Box 1072

Schenectady, NY 12301

Dr. K. Koberlein

Gesellschaft für

Reaktorsicherheit mbH

Forschungsgelände

D-8046 Garching

GERMANY

Alan Kolaczkowski

Science Applications International

Corporation

2109 Air Park Rd. S. E.

Albuquerque, NM 87106

Jim Kolanowski

Commonwealth Edison Co.

35 1st National West

Chicago, IL 60690
John G. Kollas

Institute of Nuclear Technology and

Radiation Protection

N.R.C.P.S. "Demokritos"

P.O. Box 60228

GR-153 10 Aghia Paraskevi

Attiki

GREECE

S. Kondo

Department of Nuclear Engineering

Facility of Engineering

University of Tokyo

3-1, Hongo 7, Bunkyo-ku

Tokyo

JAPAN

D. Lamy

CEN/SCK

Dept. Scientific Irradiation

Experiment \& Study BR2

Boeretang, 200

B-2400 Mol

BELGIUM

Dr. J.M. Lanore

CEA/IPSN/DAS

Centre d'Etudes Nucléaires de

Fontenay-aux-Roses

B.P. $n^{\circ} 6$

92265 Fontenay-aux-Roses CEDEX

FRANCE

Jose A. Lantaron

Consejo de Seguridad Nuclear

Sub. Analisis y Evaluaciones

Calle Justo Dorado, 11

28040 Madrid

SPAIN 
Josette Larchier-Boulanger

Electricte de France

Direction des Etudes Et Recherches 30, Rue de Conde

75006 Paris

FRANCE

\section{H. Larsen}

Head of Department

Riso National Laboratory

P.O. Box 49

DK-4000 Roskilde

DENMARK

Lawrence Livermore Nat'l Lab. (4)

Attn: George Greenly

Marvin Dickerson

Rolf Lange

Sandra Brereton

Livermore, CA 94550

Tim J. Leahy

Idaho National Engineering Lab.

LMIT MS:3850

P.O. Box 1625

Idaho Falls, ID 83415

Shengdar Lee

Yankee Atomic Electric Company 580 Main St.

Boston, MA 17407

\section{J. Lin}

PLG Inc.

Suite 400

4590 Mac Arthur Boulevard

Newport Beach, CA 92660
B.T.F. Liwaang

Dept. of Plant Safety Assessment

Swedish Nuclear Power Inspec.

P.O. Box 27106

S-10252 Stockholm

SWEDEN

Peter Lohnberg

Expresswork International, Inc.

1740 Technology Drive

San Jose, CA 95110

Steven M. Long

USNRC-NRR/SPSB

MS: 0-10E4

D. Eugenio Gil Lopez

Consejo de Seguridad Nuclear

Calle Justo Dorado, 11

28040 Madrid

SPAIN

Los Alamos National Laboratory (2)

Attn: Kent Sasser

N-6, K-557

Los Alamos, NM 87545

Christiana H. Lui

USNRC-RES/PRAB

MS: T-10E50

John Luke

Florida Power \& Light

P.O. Box 14000

Juno Beach, FL 33408

Daniel Manesse

ISPN

Boite Postale $n^{\circ} 6$

92265 Fontenay-aux-Roses CEDEX

FRANCE 
Fred Mann

Westinghouse Hanford Co.

WIA-53

P.O. Box 1970

Richland, WA 99352

Nadia Soido Falcao Martins

Comissao Nacional de Energia Nuclear

R General Severianao 90 S/408-1

Rio de Janeiro

BRAZIL

Harry F. Martz

Analysis and Assessment Division

Los Alamos National Laboratory

Los Alamos, NM 87545

Herbert Massin

Commonwealth Edison Co.

35 lst National West

Chicago, IL 60690

Hideo Matsuzuru

Tokai Research Establishment

Tokai-mur

Maka-gun

Ibaraki-ken, 319-11

JAPAN

Jim Mayberry

Ebasco Services

60 Chubb Ave.

Lyndhurst, NJ 07071

Andrew S. McClymont

IT-Delian Corporation

1340 Saratoga-Sunnyvale Rd.

Suite 206

San Jose, CA 95129
Michael McKay

Los Alamos National Laboratory

A-1, MS F600 Services

P.O. Box 1663

Los Alamos, NM87545

Zen Mendoza

SAIC

5150 El Camino Real

Suite C3 1

Los Altos, CA 94022

Dr. J. Mertens

Division of Risk Analysis \&

Reactor Technology

Institute of Safety Research

Research Centre Julich (KFA)

D-52425 Julich

GERMANY

Jim Meyer

Scientech

11821 Parklawn Dr.

Suite 100

Rockville, MD 20852

Joe Minarick

Science Applications Int'l Corp.

301 Laboratory Road

P.O. Box 2501

Oak Ridge, TN 37830

Jose I. Calvo Molins, Head

Division of P.S.A. and Human Factors

Consejo de Seguridad Nuclear

Calle Justo Dorado, 11

28040 Madrid

SPAIN

Dist-12 
David L. Morrison

USNRC-RES/DO

MS: T-10F 12

Ken Muramatsu

Risk Analysis Laboratory

Japan Atomic Energy Research Institute

Tokai-mura, Naka-gun

Ibaraki-ken, 319-11, Tokyo

JAPAN

Joseph A. Murphy

USNRC-RES/DO

MS: T-10F12

Kenneth G. Murphy, Jr.

US Department of Energy

19901 Germantown Rd.

Germantown, MD 20545

Shankaran Nair

Central Electricity

Generating Board

Berkeley Nuclear Laboratories

Berkeley

Gloucestrshire CL13 9PB

UNITED KINGDOM

Ray Ng

NEI

1776 Eye St. N

Suite 300

Washington, DC 20006-2496

G. Niederauer

Los Alamos National Laboratory

P. O. Box 1663

MSK 575

Los Alamos, NM 87545
Oak Ridge National Laboratory (2)

Attn: Steve Fisher

Sherrel Greene

MS-8057

P.O. Box 2009

Oak Ridge, TN 37831

Ken O'Brien

University of Wisconsin

Nuclear Engineering Dept.

153 Engineering Research Blvd.

Madison, WI 53706

Theresa Oh

INEL Tech Library

EG\&G MS: 2300

P. O. Box 1625

Idaho Falls, ID 83415-2300

N. R. Ortiz, Director

Nuclear Energy Technology

Division 6400

Sandia National Laboratories

Albuquerque, NM 87185

Robert Ostmeyer

U.S. Department of Energy

Rocky Flats Area Office

P. O. Box 928

Golden, CO 80402

Robert Palla

USNRC-NRR/DSSA/SCSB

MS: $0-8 \mathrm{H} 7$

Gareth Parry

NUS Corporation

910 Clopper Rd.

Gaithersburg, MD 20878 
Vern Peterson

Building T886B

EG\&G Rocky Flats

P.O. Box 464

Golden, CO 80402

\section{G. Petrangeli}

ENEA Nuclear Energy ALT Disp

Via V. Brancati, 48

00144 Rome

ITALY

Ing. Jose Antonio Becerra Perez

Comision Nacional De Seguridad

Nuclear Y Salvaguardias

Insurgentes Sur 1806

01030 Mexico, D. F.

MEXICO

Urho Pulkkinen

Technical Research Centre of

Finland

Laboratory of Electrical \&

Automation Engineeering

Otakaari 7B, 02150 Espoo 15

FINLAND

Blake Putney

Science Applications

International Corporation

5150 El Camino Real, Suite C31

Los Altos, Ca 94022

Dr. V. M. Raina

Project Manager-Risk Assessment

Ontario Hydro H1 1 G1

700 University Ave.

Toronto, Ontario M5G 1X6

CANADA
William Raisin

NEI

1726 M. St. NW

Suite 904

Washington, DC 20036

Ann Ramey-Smith

USNRC-RES/PRAB

MS: T-10E50

Dale Rasmuson

USNRC-AEOD/RRAB

MS: T-4A9

M. K. Ravindra

$\mathrm{EQE}$ International, Inc.

Suite 400

18101 Von Karman Avenue

Irvine, CA 92715

John Ridgely

USNRC-RES/AEB

MS: T-10K8

Richard Robinson (2)

USNRC-RES/PRAB

MS: T-10E50

M. Roch

Manager of Design, Nuclear

Department

TRACTEBEL

Avenue Ariane 7

B-1200 Bruxelles

BELGIUM

A.E. Rogers

General Electric Co

175 Curtner Ave

MC-489

San Jose, CA 95125 
Judy Rollstin

GRAM Inc

8500 Menual Blvd. NE

Albuquerque, NM 87112

Marc Rothschild

Halliburton NUS

1303 S. Central Ave.

Suite 202

Kent, WA 98032

Christopher Ryder

USNRC-RES/PRAB

MS: T-10E50

Takashi Sato, Deputy Manager

Nuclear Safety Engineering Section

Reactor Design Engineering Dept.

Nuclear Energy Group, Toshiba Corp. Isogo

Engineering Center

8, Shinsugita-cho, Isogo-ku,

Yokohama 235, JAPAN

Martin Sattison

Idaho National Engineering Lab.

LMIT MS: 3850

P. O. Box 1625

Idaho Falls, ID 83415-3850

Dr. U. Schmocker

Hauptabteilung für die

Sicherheit der Kernanlagen

CHI-5232 Villigen HSK

SWITZERLAND

\section{A.J. Seebregts}

ECN Nuclear Energy

Westerduinweg, 3

Postbus 1

NL-1755 Petten ZG

THE NETHERLANDS
Dr. S. Serra

Ente Naxionale per I'Energia

Electtrica (ENEL)

via G.B. Martini 3

I-00198 Rome

ITALY

H. Shapiro

Licensing \& Risk Branch

Atomic Energy of Canada Ltd.

Sheridan Park Research Comm.

Mississauga, Ontario L5K 1B2

CANADA

Richard R. Sherry

USNRC-ACRS

MS: T-2E26

Nathan O. Siu

Center for Reliability and

Risk Assessment

Idaho National Engineering Lab.

LMIT MS: 3850

P.O. Box 1625

Idaho Falls, ID 83415-3850

E. Soederman

ES-Konsult AB

Energy and Safety

P.O. Box 3096

S-16103 Bromma

SWEDEN

Themis P. Speis

USNRC-RES/DO

MS: T-10F12

Desmond Stack

Los Alamos National Laboratory

Group Q-6, Mail Stop K556

Los Alamos, NM 87545 
Jao Van de Steen

KEMA Laboratories

Utrechtseweg, 310

Postbus 9035

NL 800 ET Arnhem

THE NETHERLANDS

Eli Stern

Israel AEC Licensing Div.

P.O. Box 7061

Tel-Aviv 61070

ISRAEL

Dr. Egil Stokke

Advisory Group

OECD Halden Reactor Project

P.O. Box 173

N-1751 Halden

NORWAY

Stone \& Webster Engineering Corp

Technical Information Center

A. Hosford

245 Summer Street

245/01

Boston, MA 02210

Dennis Strenge

Pacific Northwest Laboratory

RTO/ 125

P.O. Box 999

Richland, WA 99352

R. F. Su

Tai Power

2F 78 Minchuan East Road, Section 5

Taipei

TAIWAN (Republic of China)
Technadyne Engineer. Consultants (3)

Attn: David Chanin Jeffery Foster

Walt Murfin

Suite A225

8500 Menual Blvd. N

Albuquerque, NM 87112

Ashok Thadani

USNRC-NRR/ADT

MS: O-12G18

T. G. Theofanous

University of California, S. B.

Department of Chemical and Nuclear

Engineering

Santa Barbara, CA 93106

Catherine Thompson

USNRC-RES/PRAB

MS: T-10E50

Soren Thykier-Nielsen

Riso National Laboratory

Postbox 49

DK4000 Roskile

DENMARK

\section{W. H. Tong}

EQE International, Inc.

Suite 400

18101 Von Karman Avenue

Irvine, CA 92715

R. Toossi

Physical Research, Inc. 25500 Hawthorn Blvd.

Torrance, CA 90505 
Ennio Traine

ENEL

Via Vialiano, 48

00144 Rome

ITALY

Ulf Tveten

Environmental Physics Section

Institutt for Energiteknikk

Postboks 40

N-2007 Kjeller

NORWAY

US Department of Energy

Energy Library

Room G 034/GTN

AD-622.1

Washington, DC 20585

US Department of Energy

NS-50 (GTN)

NS-10.1

S-161

Washington, DC 20585

U.S. Environmental

Protection Agency (2)

Attn: Allen Richardson

Joe Logsdon

Office of Radiation Programs

Environmental Analysis Division

Washington, DC 20460

\section{Harold VanderMolen}

USNRC-RES/PRAB

MS: T-10E50

Dr. A. Valeri

A.N.P.A.

Via Vitaliano Brancati, 48

I-00144 Rome

ITALY
Magiel F. Versteeg

Ministry of Social Affairs

and Employment

P.O. Box 90804

2509 LV Den Haag

THE NETHERLANDS

Martin Virgilio

USNRC-NRR/DSSA

MS: O-8E2

R. Virolainen, (Chairman PWG5)

Systems Integ. Off. (STUK)

P.O. Box 268

Kumpulanite 7

SF-60101 Helsinki

FINLAND

Seppo Vuori

Technical Research Centre of Finland

Nuclear Engineering Laboratory

Lonnrotinkatu 37

P.O. Box 169

Sf-00181 Helsinki 18

FINLAND

Dr. Ian B. Wall

81 Irving Avenue

Atherton, CA 94027

Edward Warman

Stone \& Webster Engineering Corp.

P.O. Box 2325

Boston, MA 02107

J.E. Werner

Reactor Research \& Techn Division

US DOE Idaho Operations

MS: 1219

850 Energy Drive

Idaho Falls, ID 83401-1563 
Dr. Wolfgang Werner

Safety Assessment Consulting $\mathrm{GmbH}$

Veilchenweg 8

D 83254 Breitbrunn

GERMANY

Westinghouse Electric Corp

Technical Library

P. O. Box 355

East 209

Pittsburgh, PA 15230

Westinghouse Electric Corp

NTD

Central File Nuclear Safety

P. O. Box 355

408 1-A

Pittsburgh, PA 15230

Westinghouse Electric Company (3)

Attn: John Lacovin

Burt Morris

Griff Holmes

Energy Center East, BIdg. 371

P.O. Box 355

Pittsburgh, PA 15230

Westinghouse Savannah River Co. (2)

Attn: Kevin O'Kula

Jackie East

Safety Technology Section

1991 S. Centennial Ave., Bldg. 1

Aiken, SC 29803

Donnie Whitehead

Department 6412, MS: 0747

Sandia National Laboratories

P.O. Box 5800

Albuquerque, NM 87185-0747
Keith Woodard

PLG, Inc.

7315 Wisconsin Ave.

Suite 620 East

Bethesda, MD 20814-3209

John Wreathall

The WreathWood Group

4157 MacDuff Way

Dublin, $\mathrm{OH} 43016$

Carlo Zaffiro

A.N.P.A.

Directorate for Nuclear

Via Vitaliano Brancate, 48

I-00144 Rome

ITALY

Dr. X. Zikidis

Greek Atomic Energy Comm.

N.R.C.P.S. "Demokritos"

GR-153 10 Agia Paraskevi

Attiki

GREECE

Internal Distribution

R. A. Bari, Bldg. 197C

John Baum, Bldg $703 \mathrm{M}$

L. Chu, Bldg. 130

D. Diamond, Bldg. 130

J. Jo, Bldg. 130

P. Kohut, Bldg. 475B

C. C. Lin, Bldg. 130

V. Mubayi, Bldg. 130

Z. Musicki, Bldg. 130

L. Neymotin, Bldg. 130

W. T. Pratt, Bldg. 130

A. Tingle, Bldg. 197C

S. M. Wong, Bldg. 130

J. W. Yang, Bldg. 130

R. Youngblood, Bldg. 130 
Vol. 1

2. TITLE AND SUBTITLF

Evaluation of Potential Severe Accidents During Low Power and Shutdown Operations at Surry, Unit I:

3. DATE REPORT PUBUSHED \begin{tabular}{l|l} 
MONTH & YEAR
\end{tabular}

October

Summary of Results

6. AUTHOR(S)

Edited by T. L. Chu and W. T. Pratt

4. FIN OR GRANT NUMBER

L-1922

6. TYPE OF REPORT

Technical

7. PERIOD COVERED (Inclusivo Dates)

09/01/90 - 09/30/95

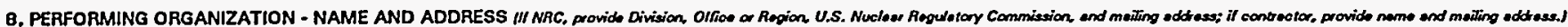

Brookhaven National Laboratory

Department of Advanced Technology, Bldg. 130

P.O. Box 5000

Upton, New York 11973-5000

9, SPONSORING ORGANIZATION - NAME AND ADDRESS II NRC, npe "Seme as ebove; if contrector, provide NRC Division, Office or Ragion, U.S. Nuclear Reguletory Commission and meiting adtrass.)

Division of Systems Technology

Office of Nuclear Regulatory Research

U.S. Nuclear Regualtory Commission

Washington, DC 20555-0001

10. SUPPLEMENTARY nOTES R. Robinson, NRC Project Manager

11. ABSTRACT (200 words or bes)

This document contains a summarization of the results and insights from the Level 1 accident sequence analyses of internally initiated events, internally initiated fire and flood events, seismically initiated events, and the Level $2 / 3$ risk analysis of internally initiated events (excluding fire and flood) for Surry, Unit 1. The analysis was confined to mid-loop operation, which can occur during three plant operational states (identified as POSs R6 and R10 during a refueling outage, and POS D6 during drained maintenance). The report summarizes the Level 1 information contained in Volumes 2 - 5 and the Level 2/3 information contained in Volume 6 of NUREG/CR-6144.

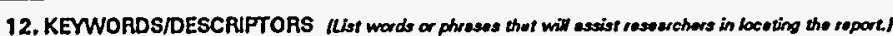

Low Power and Shutdown, Probabilistic Risk Assessment, PRA, PWR, Risk, Surry, Plant Operational State, Insights, Mid-loop, Internal Events, Fire, Flood, Seismic
3. AVAILABILTTY STATEMENT

Unlimited

14. SECURITY CLASSIFICATION (This Pogal

UT

Unclassified

Unclassified

16. NUMBER OF PAGES

16. PRICE 


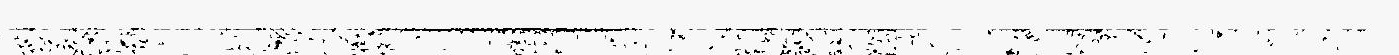




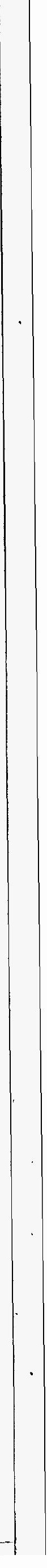




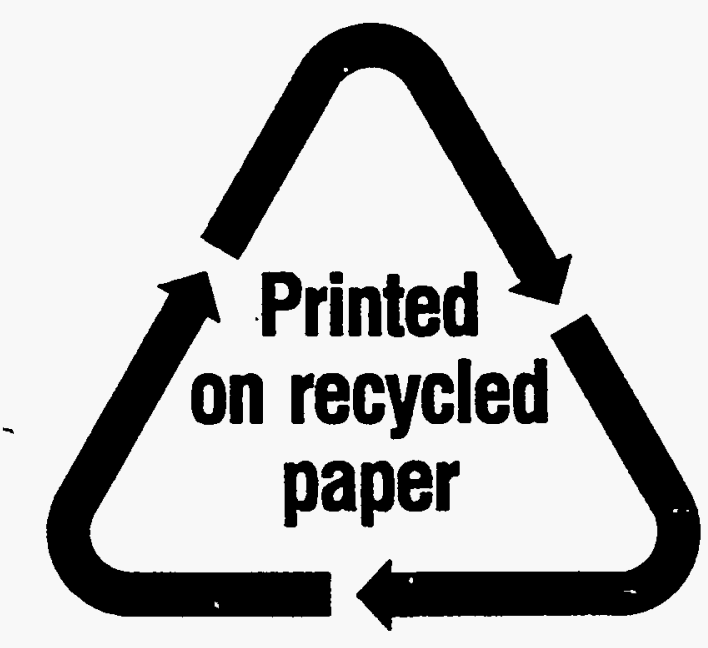

Federal Recycling Program 